\title{
LA PLANIFICACIÓN AMBIENTAL EN COLOMBIA
}

TRABAJO DE INVESTIGACIÓN

\author{
LUDWING MANTILLA CASTRO
}

\section{UNIVERSIDAD SANTO TOMAS}

FACULTAD DE DERECHO

MAESTRIA EN DERECHO

BOGOTA D.C.

2015 


\section{Contenido}

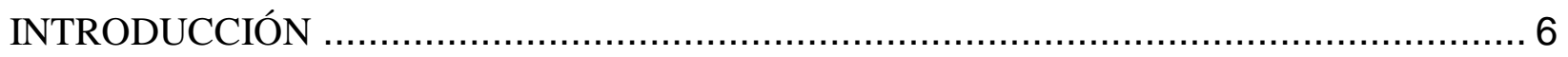

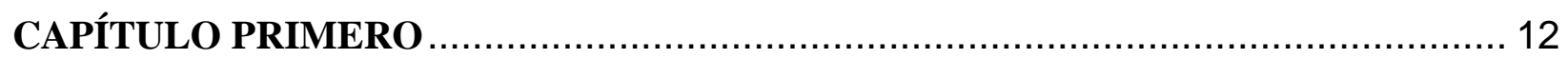

LA PLANIFICACIÓN AMBIENTAL EN LA CONSTITUCIÓN POLÍTICA .................. 12

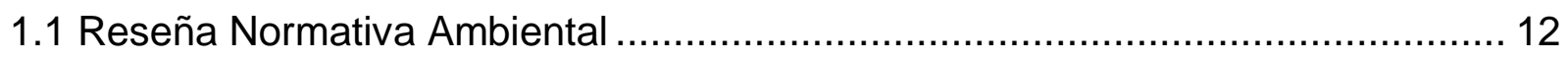

1.2 La Constitución Verde de Colombia, 1991 ................................................... 16

1.2.1 Título I. De Los Principios Fundamentales. Art. 1 - 10 .................................... 17

1.2.2 Título II. De Los Derechos, Las Garantías Y Los Deberes. Art. 11 - 95 .................. 18

1.2.3 Título III. De Los Habitantes Y Del Territorio. Art. 96 - 102 …........................ 26

1.2.4 Título IV. De La Participación Democrática y Partidos Políticos. Art. 103 - 112..... 26

1.2.5 Título V. De La Organización del Estado. Art. 113 - 131 …............................. 27

1.2.6 Título VI. De La Rama Legislativa. Art. 132 - 187....................................... 27

1.2.7 Título VII. De La Rama Ejecutiva. Art. 188 - 227 ......................................... 27

1.2.8 Título VIII. De La Rama Judicial. Art. 228 - 257 …....................................... 28

1.2.9 Título IX. De Las Elecciones Y De La Organización Electoral. Art. 258 - 266 ....... 30

1.3.0 Título X. De Los Organismos De Control. Art. 267 - 284 .................................... 30

1.3.1 Título XI. De La Organización Territorial. Art. 285 - 331 ................................... 31

1.3.2 Título XII. Del Régimen Económico Y De La Hacienda Pública. Art. 332 - 373 .... 35

1.3.3 Título XIII. De La Reforma De La Constitución. Art. 374 - 380 .......................... 43

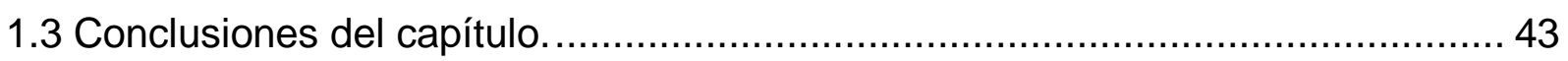

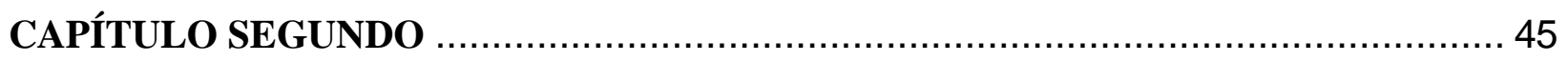

LA PLANIFICACIÓN AMBIENTAL FUNCIÓN DE LAS AUTORIDADES PÚBLICAS .... 45

2.1 Del Ministerio de Ambiente y Desarrollo Sostenible - MADS ........................... 46

2.2 De la Autoridad Nacional de Licencias Ambientales - ANLA .......................... 51

2.3 De la Unidad Administrativa Especial de Parques Nacionales Naturales ........ 53 
2.4 De las Corporaciones Autónomas Regionales - CAR ........................................ 56

2.5 De los Departamentos y Asamblea Departamental .......................................... 59

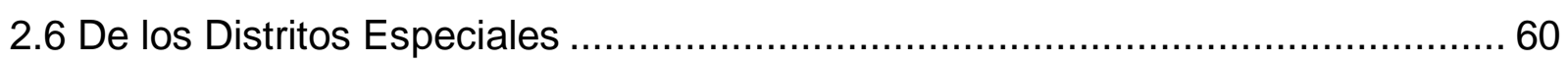

2.7 De los Grandes Centros Urbanos y Áreas Metropolitanas................................. 62

2.8 De los Municipios y Concejos Municipales ……............................................ 64

2.9 Otras Entidades que Ejercen Funciones Ambientales ....................................... 66

2.9.1 De la Procuraduría General de la Nación ........................................................ 66

2.9.2 De la Defensoría del Pueblo - Personero Municipal........................................... 67

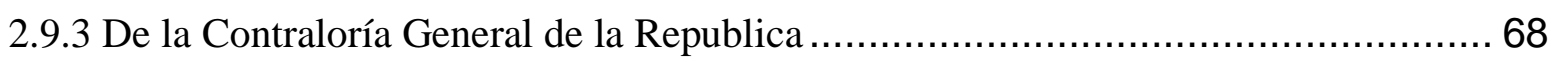

2.9.4 De la Fiscalía General de la Nación - CTI...................................................... 68

2.9.5 De las Entidades Adscritas y Vinculadas al Ministerio de Ambiente - MADS ......... 69

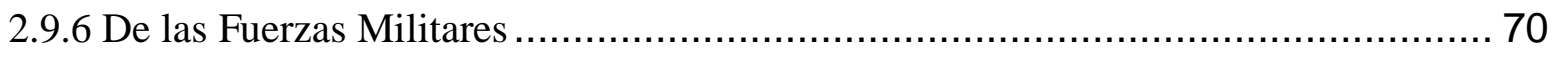

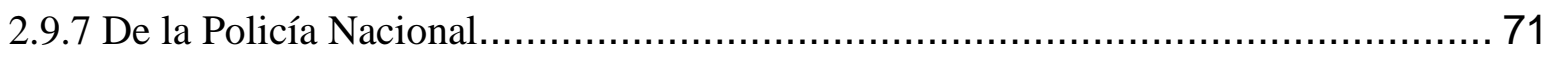

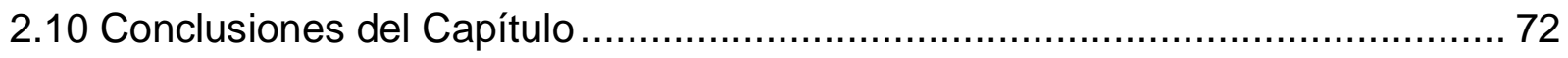

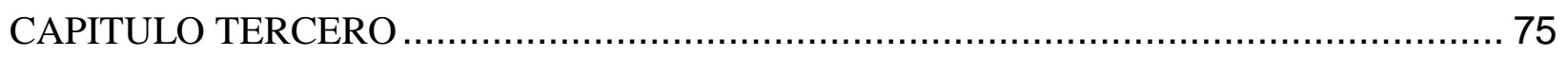

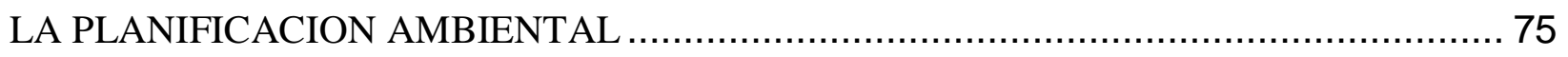

3.1 Contexto Interno sobre la Planificación Ambiental ........................................... 75

3.1.1 Nacimiento de la Planificación Ambiental en Colombia..................................... 76

3.1.2 Definición, Utilidad y Finalidad de la Planificación Ambiental ............................ 79

3.1.2.1 ¿En qué consiste la Planificación ambiental? Definición................................... 80

3.1.2.2 ¿Para qué sirve la Planificación Ambiental? Utilidad ....................................... 88

3.1.2.3 ¿Qué busca la Planificación Ambiental? Finalidad ......................................... 89

3.1.3 Reseña Legislativa sobre temas similares ................................................... 90

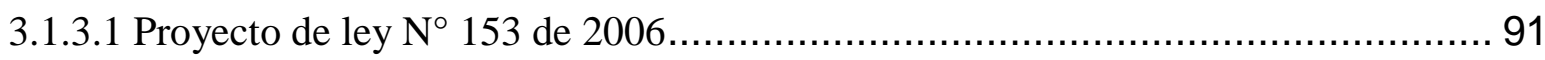

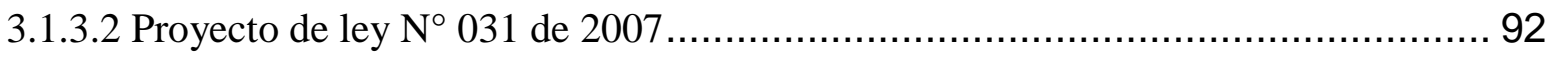




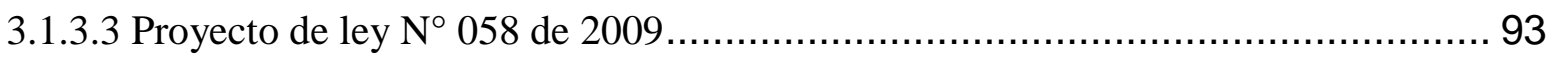

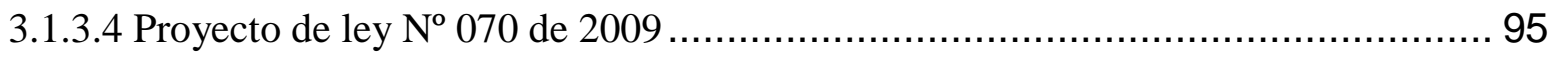

3.2 Contexto Externo sobre la Planificación Ambiental ............................................ 97

3.3 Sistema de Planificación Ambiental Nacional - SISPAN ................................. 103

3.3.1 Que tenemos? Diagnóstico de los recursos naturales renovables......................... 104

3.3.2 Cuánto valen? Contabilidad ambiental .................................................... 108

3.3.3 Como lo vamos a utilizar? Ordenamiento Ambiental ..................................... 115

3.3.4 ¿Con qué lo vamos a recuperar? Política Ambiental Preventiva.......................... 119

3.3.5 Qué vamos a entregar a cambio? La Responsabilidad Social Ambiental............... 122

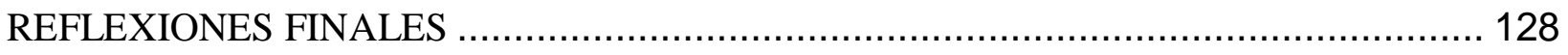

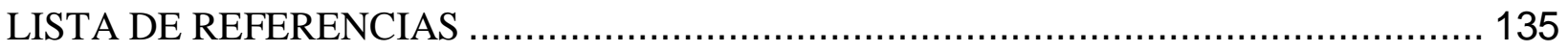




\section{LA PLANIFICACIÓN AMBIENTAL EN COLOMBIA}

\section{RESUMEN}

La contaminación ambiental y el agotamiento de los recursos naturales renovables dejaron de ser un problema del futuro, es la realidad actual, está afectando lo más valioso de un ser humano, su propia vida. Al respecto el Estado Colombiano tiene como obligación Constitucional realizar la planificación en el manejo y aprovechamiento de los recursos naturales a fin de garantizar su desarrollo sostenible. Se concluye que este precepto tan importante es incumplido por la inexistencia de su reglamentación y es ahí donde surge nuestra propuesta de convertir en una realidad legal la responsabilidad social ambiental, encaminada a realizar la planificación ambiental, minimizar los factores de deterioro, fijar compensaciones previas y definir políticas sociales ambientales vinculantes, en busca de proteger el ambiente, NUESTRA VIDA.

\section{ABSTRACT}

The pollution and depletion of renewable natural resources, is not a future problem anymore, now its part of our present and part of our lifes, it is what we called real world, and it is affecting the most valuable thing of the society, like it's the human life. For that reason the Colombian Government has the constitutional obligation to plan the use of natural resources with the objective of ensuring the sustainable development. It may be concluded that this important precept is violated by the absence of regulations and that is where our proposal emerged, in order to change a legal environmental and social responsibility reality to make environmental planning, minimize deteriorated factors, establish previous compensations and define social and environmental standards, to protect the environment, OUR OWN LIFE.

Palabras claves: Planificación de los recursos naturales renovables, sistema de planificación ambiental nacional, responsabilidad social ambiental, autoridades ambientales, marco jurídico ambiental, constitución política verde, desarrollo sostenible moderno.

Keywords: Planinng of renewable natural resources, national environmental planning system, social environmental responsabilty, environmental authorities, environmental legislation, green politic constitution, modern sustainable development. 


\section{LA PLANIFICACIÓN AMBIENTAL EN COLOMBIA}

\section{INTRODUCCIÓN}

Con agrado se afirma que el Estatuto Constitucional Colombiano de 1991, está integrado por un articulado cargado de directrices a favor y en protección del ambiente, donde a las diferentes entidades del Estado se le atribuyeron unas obligaciones y el cumplimiento de determinadas funciones ambientales, y a los particulares, de igual forma, se le impartieron obligaciones similares y la realización de sus actividades en armonía con el desarrollo sostenible y la protección de las riquezas naturales de la Nación.

El desarrollo sostenible en Colombia se convirtió indudablemente en una novedad institucional dentro de la Constitución Política, y conllevó a elevar un articulado ambiental al rango Constitucional. Es así, como en el artículo $80 \mathrm{CP}$, resalta la obligación del Estado de planificar "el manejo y aprovechamiento de los recursos naturales, para garantizar su desarrollo sostenible, su conservación, restauración o sustitución. Además, deberá prevenir y controlar los factores de deterioro ambiental, imponer las sanciones legales y exigir la reparación de los daños causados" (Constitución Política, 1991).

Resulta pertinente traer a colación la definición de desarrollo sostenible incluida en el Informe de Brundtland - Informe de la Comisión Mundial sobre el Medio Ambiente y el Desarrollo, como modelo de crecimiento desarrollado "que satisface las necesidades de las presente generación sin comprometer la capacidad de las generaciones futuras para satisfacer sus propias necesidades" (ONU, 1987, p. 46)

Y contrario a lo precedente, en Colombia las infracciones y afectaciones ambientales son reiterativas, aunado al deterioro progresivo de los recursos naturales renovables, día a día observamos que las aguas están más contaminadas, el aire menos puro, el suelo en vía de degradación y erosión, la lluvia ácida, la fauna y flora silvestre en vía de extinción y deforestación, las franjas y rondas de protección intervenidas, la sequía y el bajo nivel ecológico de las fuentes hídricas, los aumentos de temperaturas y la afectación de la zona de glaciares; consecuencias del cambio climático (calentamiento global), el crecimiento natural de la población y la sobreexplotación de los ecosistemas naturales por la falta de planificación ambiental por parte del Estado. 
De acuerdo con la evaluación preliminar (Primera Comunicación Nacional de Colombia) efectuada por parte del IDEAM, como efectos del cambio climático se han identificado determinadas amenazas ambientales en el territorio nacional, entre ellas:

El incremento del nivel del mar, se estableció que hacia el 2050-2060 podría presentarse un aumento alrededor de 40 o 60 centímetros en las costas Caribe y Pacífico colombianas, respectivamente, en relación con el promedio de 1961-1990. En relación con la temperatura del aire se estima que hacia el 2050-2060 podría darse un aumento de la temperatura anual del aire entre $1^{\circ} \mathrm{C}$ y $2^{\circ} \mathrm{C}$. En cuanto a la precipitación, se estiman cambios variados para diferentes regiones (aumento para algunas, disminución para otras) que estarían diferenciadamente entre $\pm 15 \%$. (IDEAM, 2009)

En igual sentido la Contraloría General de la República en su "Informe sobre el estado de los recursos naturales y del ambiente", afirmó que:

Por último, en torno a la evaluación general del impacto de los instrumentos para la gestión ambiental en Colombia, la información disponible sobre los indicadores de estado de los recursos naturales (deforestación, contaminación de fuentes hídricas y del aire, e índice de aridez) muestra, desafortunadamente, que han tenido un impacto marginal en el mejoramiento de la cantidad y calidad del medio ambiente y los recursos naturales. (Contraloría General de la República, 2013, Pp. 18 y 19)

En este contexto, es claro precisar el compromiso que implica para los entes gubernamentales que ejercen autoridad ambiental, la obligación de planificar los recursos naturales renovables y dar aplicación a lo esbozado por la jurisprudencia Constitucional frente a los derechos y obligaciones recíprocas, consignadas mediante sentencia C-059 de 1994, afirmó:

El medio ambiente, en la Constitución Política, representa una dualidad en el sentido de que ha sido calificado como un derecho-deber. Es un derecho por cuanto ha sido señalado específicamente como tal y, además, se encuentra íntimamente ligado con la salud, la vida y la integridad física de los asociados. Y también es un deber por cuanto exige de las autoridades y de los particulares acciones encaminadas a su protección. (Colombia, Sentencia, 1994)

En otro contexto, desde la óptica internacional ha de predicarse que la protección ambiental es un argumento de moda para los diferentes países, convirtiéndose en un tema global 
de extrema necesidad para la humanidad, por ser los recursos naturales renovables como el agua, el aire, la fauna, entre otros, un alimento único, irremplazable y esencial para la vida humana; a diferencia de los recursos naturales renovables como el oro, la plata, etc., los cuales pueden ser remplazados por otros metales, y es por ello, que la vida continuaría su camino con otras alternativas no esenciales.

De igual manera, se observa que la responsabilidad y planificación ambiental existe en otros países en armonía con el desarrollo sostenible, entre ellos Argentina - Provincia de Buenos Aires, donde se profirió la ley $\mathrm{N}^{\circ} 11.723$ de 1995 sobre protección, conservación, mejoramiento y restauración de los recursos naturales y del ambiente en general, y en su artículo $5^{\circ}$, inciso d) afirma que "La planificación del crecimiento urbano e industrial deberá tener en cuenta, entre otros los límites físicos del área en cuestión, las condiciones de mínimo subsidio energético el impacto ambiental para el suministro de recursos y servicios...", y continua la norma enunciada, puntualmente en su artículo $6^{\circ}$ en precisar que "El Estado provincial y los municipios tienen la obligación de fiscalizar las acciones antrópicas que puedan producir un menoscabo al ambiente, siendo responsables de las acciones y de las omisiones en que incurran” (Nación y Provincia de Buenos Aires, 2011, P. 279); lo preliminar, en similitud a lo consignado en el artículo 80 Constitucional Colombiano, sobre la planificación de los recursos naturales renovables, siendo una expectativa sin aterrizar por parte del Estado.

Corolario de lo discurrido, precisamos que no se trata de inundar a un Estado de normas dispersas en materia ambiental, es necesario construir un piso único legal enfocado en la planificación del manejo y aprovechamiento de los recursos naturales, enmarcado dentro de la responsabilidad social ambiental y el cumplimiento de los preceptos Constitucionales en materia ambiental por parte del Estado.

En ese marco jurídico excesivamente disperso, concurren unas autoridades ambientales en Colombia encargadas de la evaluación, expedición, control y seguimiento a los permisos, licencias y autorizaciones ambientales en cada una de las empresas e industrias existentes y de la aplicación del régimen administrativo sancionatorio y penal por incumplimiento a las normas ambientales, por daños y afectaciones contra los recursos naturales renovables; emerge la inquietud, si dentro de las funciones asignadas a las autoridades ambientales, se tipifica la de realizar una planificación en el manejo de los recursos naturales. 
La responsabilidad social ambiental en Colombia viene en un proceso de desarrollo, de evolución sin norte definido; lo anterior como consecuencia de la vigencia de un marco jurídico ambiental disperso y frente a una realidad sin horizonte jurídico; no concurre a la fecha un análisis de la ruta evolutiva normativa de la planificación ambiental, puntualizando en la inexistencia de un diagnóstico de la calidad y cantidad frente a ciertos recursos naturales renovables, en la protección, conservación o restauración ambiental por parte de algunas autoridades ambientales, en paralelo con el utópico e invisible compromiso ambiental del sector industrial y empresarial, que día a día en su práctica utilizan los recursos naturales renovables conllevando al deterioro y degradación del ambiente.

Los problemas, conflictos y dificultades frente a la falta de planificación ambiental son concretos; de una parte la ausencia del cumplimiento a lo estipulado en el artículo 80 de la Constitución Política, conllevando a un ejercicio no efectivo por parte de algunas autoridades públicas; y de otra parte, la ausencia de una política pública de responsabilidad social ambiental Estatal frente a la planificación u ordenamiento ambiental. Se puede afirmar que no existe un conocimiento absoluto frente a la planificación de los recursos naturales en los diferentes escenarios, sean públicos o privados.

Y es el concepto de planificación en el manejo y aprovechamiento de los recursos naturales sinónimos de ordenamiento ambiental y/o planificación ambiental, así:

Proceso racional de toma de decisiones en el que intervienen los datos del medio ambiente. El proceso mediante el cual se intenta concretar, con respecto al sistema ambiental, sujeto del manejo, aquellas aspiraciones definidas como positivas por el sistema de valores más representativo de los intereses de la población afectada, con las intervenciones que se llevan a cabo en el sistema ecológico que integran la población en cuestión y su correspondiente sistema ambiental. (Rodriguez, 1995)

En esta línea, podría definirse la planificación ambiental como un instrumento de gestión pública, que conlleva un diagnóstico medible de los recursos naturales renovables, soporte para la toma de decisiones y directrices sostenibles. Hoy sin análisis frente al tema; resultaría trascendental proponer un modelo de marco legal o parte de él, con base en la responsabilidad social ambiental a fin de comprometer al Estado de dar cumplimiento a lo dispuesto en el artículo 80 del Estatuto Constitucional, en armonía con la planificación del aprovechamiento de 
los recursos naturales para garantizar su desarrollo sostenible, su conservación y la prevención de los factores de deterioro ambiental, y respecto a las personas jurídicas de derecho público que incluyan determinadas medidas o acciones a favor del ambiente.

Es pues, en este preciso contexto que hemos decidido plantearnos la siguiente problemática jurídica: Es pues, en este preciso contexto que hemos decidido plantearnos la siguiente problemática jurídica: ¿Con la reglamentación legal existente, se está dando cumplimiento a la obligación del Estado de planificar el manejo y aprovechamiento de los recursos naturales, su conservación, restauración o sustitución a fin de garantizar el desarrollo sostenible, de conformidad con lo dispuesto en el artículo 80 de la Constitución Política de Colombia?

Es por lo anterior, que la presente investigación tiene como objetivo general el de determinar la conformación de la estructura legal de la planificación de los recursos naturales como obligación Estatal de acuerdo con lo establecido en el artículo 80 de la Constitución Política de Colombia. De esta forma, estaríamos identificando y proponiendo una reglamentación frente al vacío normativo ambiental.

Con el ánimo de responder el anterior cuestionamiento y para cumplir este objetivo general abordaremos el siguiente plan de trabajo: en un primer término, nos ocuparemos de la planificación ambiental en la Constitución Política de Colombia (I); en segundo lugar, definiremos a las autoridades ambientales, su reglamentación legal y funciones de planificación ambiental (II); y en tercer lugar concluiremos, si en Colombia el marco regulatorio ambiental permite establecer la existencia y aplicación de la planificación en el manejo y aprovechamiento de los recursos naturales, para garantizar su desarrollo sostenible Constitucional (III).

Respecto al tema ambiental se ha expedido diferente normatividad, materializada en leyes, decretos, resoluciones, circulares, en fin, un sinnúmero de actos legales y administrativos, donde se vislumbra un marco normativo ambiental amplio, diverso y disperso; hoy a buena hora, el Ministerio de Ambiente y Desarrollo Sostenible expidió el decreto 1076 de 2015, por el cual se realizó una compilación reglamentaria para el sector ambiente y desarrollo sostenible, un gran avance, recomendándose ser insumo para dar trámite legislativo a fin de proferir el Código 
Único Nacional Ambiental - CUNA, en armonía con lo dispuesto en la reciente ley 1753 de 2015 "Plan Nacional de Desarrollo 2014 - 2018".

Es aquí, desde ésta perspectiva, que se observa la necesidad de plantear la hipótesis de la presente investigación al analizar que no hay reglamentación normativa suficiente frente al postulado Constitucional (art. 80) asignado al Estado de realizar la planificación en el manejo y aprovechamiento de los recursos naturales en nuestro país, para garantizar plenamente su desarrollo sostenible, su conservación, restauración o sustitución.

En nuestro caso concreto, para proceder al inicio y desarrollo de lo planteado, precisamos de un enfoque cualitativo y una investigación descriptiva, como diseño metodológico enfocado a la forma para llegar a los objetivos propuestos. Así las cosas, se realizará una revisión normativa vigente en orden cronológico y la visión jurisprudencial en materia ambiental en Colombia como apoyo argumentativo, seleccionadas por sus criterios relevantes (Narváez, 2013), de acuerdo a la estructura: Estatuto Constitucional ambiental, autoridades y funciones ambientales y la garantía del desarrollo sostenible; para luego identificar parte de la bibliografía nacional e internacional, el análisis de contenido de textos y tratados ambientales, la observación directa de los hechos y noticias en diferentes medios de comunicación frente a la problemática ambiental y la ausencia de la planificación de los recursos naturales renovables, y así, lograr el registro sistemático frente al tema de investigación. 


\section{CAPÍTULO PRIMERO}

\section{LA PLANIFICACIÓN AMBIENTAL EN LA CONSTITUCIÓN POLÍTICA}

En este aparte se identificarán los tratados, leyes y decretos ambientales antes y después del Estatuto Constitucional Colombiano de 1991, con mayor trascendencia para la presente investigación; seguido analizaremos artículo por artículo de la Constitución Política con esencia ambiental, a fin de determinar cuáles son las obligaciones y responsabilidades del Estado frente a la planificación, protección, conservación, restauración, prevención y control ambiental. De otra parte, identificar los deberes Constitucionales de las personas naturales y jurídicas frente a minimizar los factores de deterioró ambiental y la reparación de los daños causados a los recursos naturales renovables dentro del precepto de la planificación ambiental.

Antes de abordar el presente capítulo, es pertinente realizar un esbozo de las diferentes fechas sobre la evolución del marco legal ambiental en el mundo y en Colombia con relación a la planificación ambiental, el cual trasciende desde 1972 a la actualidad.

\subsection{Reseña Normativa Ambiental}

En relación con el tema enunciado, nos remontamos a 1972, año en el cual se realiza la Declaración de la Conferencia de las Naciones Unidas sobre el Medio Humano, aprobada el 16 de junio en Estocolmo - Suecia, como respuesta a la evidente necesidad de un criterio y unos principios comunes que requerían los pueblos del mundo, como una guía para preservar y mejorar el medio humano; entre ellos se encuentra el principio $\mathrm{N}^{\circ} 2$, que precisa:

Los recursos naturales de la Tierra, incluidos el aire, el agua, la tierra, la flora y la fauna, y especialmente muestras representativas de los ecosistemas naturales, deben preservarse en beneficio de las generaciones presentes y futuras mediante una cuidadosa planificación $u$ ordenación, según convenga.

Así mismo el principio $\mathrm{N}^{\circ} 15$, que afirma "Debe aplicarse la planificación a los asentamientos humanos y a la urbanización con miras a evitar repercusiones perjudiciales sobre el medio y a obtener los máximos beneficios sociales, económicos y ambientales para todos”. Es decir, más de cuarenta años que se afirmó por los diferentes países del mundo, la obligatoriedad de realizar una cuidadosa planificación u ordenación ambiental a fin de preservar los recursos 
naturales en benefició de los que están por nacer; este precepto de planificación ambiental y de los recursos naturales fue elevado a rango Constitucional por el Estado Colombiano. (Subrayado fuera de texto). Y es en esta anualidad que se materializa la creación del Programa de Naciones Unidas para el Medio Ambiente (PNUMA).

En Colombia, se expide la ley 23 de 1973 "Por la cual se conceden facultades extraordinarias al Presidente de la República de Colombia para expedir el Código de recursos naturales y de protección al medio ambiente y se dictan otras disposiciones", firmada el 12 de diciembre de 1973, un año después de la declaración de la Conferencia de las Naciones Unidas antes mencionada. El objeto de la ley 23 de 1973, según el artículo primero es el de "prevenir y controlar la contaminación del medio ambiente y buscar el mejoramiento, conservación y restauración de los recursos naturales renovables para defender la salud y el bienestar de todos los habitantes del territorio nacional". Por su parte, su artículo $2^{\circ}$, establece que:

El medio ambiente es un patrimonio común; por lo tanto su mejoramiento y conservación son actividades de utilidad pública, en las que deberán participar el Estado y los particulares. Para efectos de la presente ley, se entenderá que el medio ambiente está constituido por la atmósfera y los recursos naturales renovables. (Colombia, Congreso Nacional de la República, 1973)

Trasciende la importancia de esta norma en las facultades otorgadas al Presidente de la República para que al año siguiente (1974), profiriera el hoy vigente Código Nacional de los Recursos Naturales y de Protección del Medio Ambiente. No sobra precisar que en la actualidad la Constitución Política en su artículo 150, prohibió revestir al Presidente de la República de facultades para expedir códigos en ningún ramo de la legislación, ya que es una función exclusiva del Congreso de la República (numerales 2 y 10 del artículo 150 CP, 1991).

En 1974, en diciembre 18 se pública el decreto ley 2811 de 1974 "Por el cual se dicta el Código nacional de recursos naturales renovables y de protección al medio ambiente" y se funda en el principio de que el ambiente es patrimonio común de la humanidad y necesario para la supervivencia y el desarrollo económico y social de los pueblos; y en su artículo 45 detalla que el manejo de los recursos naturales renovables “g). Se asegurará mediante la planeación en todos los niveles la compatibilidad entre la necesidad de lograr el desarrollo económico del país y la aplicación de la política ambiental y de los recursos naturales”. 
En tanto que, en 1987 se llevó a cabo la Comisión Mundial sobre el Medio Ambiente y el Desarrollo, se produjo el Informe Brundtland, denominado: Nuestro Futuro Común “Our Common Future", en el cual por primera vez se incluyó el concepto de desarrollo sostenible.

Posteriormente vienen una serie de reglamentaciones legales en materia ambiental de forma dispersa, y es en el año 1991 con la expedición de la Constitución Política se da inicio a nivel nacional de una nueva época proteccionista frente a los recursos naturales renovables.

Puntualmente fue el rango Constitucional que se le dio a la protección y restauración de los recursos naturales renovables, el derecho-deber del Estado y de las personas de proteger las riquezas naturales, la "ecologización” de la propiedad privada (obligación de la propiedad a cumplir una función ecológica), la inalienabilidad, imprescriptibilidad e inembargabilidad de los bienes de uso público, el derecho de todas las personas a gozar de un ambiente sano, la protección de la diversidad e integridad del ambiente, el fomento de la educación ambiental y la planificación ambiental. Todo lo precedente, enmarcado en los principios filantrópicos ambientales consagrados en la "Constitución Verde de Colombia".

Un año después, es decir en 1992, se realizó la Cumbre de la Tierra o Conferencia de las Naciones Unidas sobre el Medio Ambiente y el Desarrollo, en Río de Janeiro - Brasil del 3 al 14 de junio contando con la participación de 173 Estados y la asistencia de 118 Jefes de Estado y de Gobierno y en la cual se aprobó la “Agenda 21”, con el objetivo de:

Establecer una alianza mundial nueva y equitativa mediante la creación de nuevos niveles de cooperación entre los Estados, los sectores claves de las sociedades y las personas, procurando alcanzar acuerdos internacionales en los que se respeten los intereses de todos y se proteja la integridad del sistema ambiental y de desarrollo mundial, primando los seres humanos con el desarrollo sostenible. (ONU, 1992).

Y es en diciembre 22 de 1993 que se expide la ley 99, por medio de la cual se creó el Ministerio del Medio Ambiente (Hoy, Ministerio de Ambiente y Desarrollo Sostenible) se reordena el sector público encargado de la gestión y conservación del medio ambiente y los recursos naturales renovables, se organiza el Sistema Nacional Ambiental - SINA, y se definió que la política ambiental colombiana se fundamentará en unos principios generales ambientales. 
Posteriormente se profieren diferentes reglamentaciones, acuerdos, convenciones y tratados internacionales, entre ellos: El "Protocolo de Kioto de la Convención Marco de la Organización de las Naciones Unidas sobre Cambio Climático - UNFCCC”, el cual fue aprobado en la ciudad de Kioto - Japón (1997).

En el 2000 se llevó a cabo la Declaración de la Asamblea General de las Naciones Unidas conocida como la Cumbre del Milenio, en la cual se establecieron objetivos para el mundo en materia de sostenibilidad ambiental, los cuales tienen su esencia una vez sean incorporados en los procesos de planificación ambiental nacional, regional y local.

Y en el 2002 se emitió el informe de la Cumbre Mundial sobre el Desarrollo Sostenible de la Organización de las Naciones Unidas, en Johannesburgo (Sudáfrica) el 26 de agosto al 04 de septiembre de 2002, del cual se desprendieron unos compromisos frente a la activa participación de las autoridades ambientales, por consiguiente es sustancial que los instrumentos de planificación se encuentren dentro de sus funciones.

Pasaron diez (10) años desde de la histórica Cumbre de la Tierra realizada en Río de Janeiro (ONU, 1992); y veinte años después se realiza la Conferencia de las naciones unidas sobre el desarrollo sostenible nuevamente en Río de Janeiro del 20 al 22 de junio del 2012, conocida como RIO + 20; más adelante en el último capítulo de la presente investigación disertaremos sobre las conclusiones de esta cumbre mundial ambientalista.

De igual manera, el Programa de las Naciones Unidas para el Desarrollo (PNUD) de la ONU con presencia de 177 países y territorios, viene liderando ocho (8) objetivos de desarrollo del milenio (ODM) para el año 2015, entre ellos indudablemente se encuentra el componente ambiental, $N^{\circ} 7$ "Garantizar la sostenibilidad del medio ambiente", conllevando implícitamente la planificación ambiental; y fue en el año 2014, donde se emitió un informe examinando los más recientes avances hacia el logro de los ODM, concluyendo que:

Todos los años se pierden millones de hectáreas de bosques, muchas especies son empujadas aún más hacia su extinción y las fuentes renovables de agua se vuelven cada vez más escasas. En todo el mundo continúa la tendencia al alza de las emisiones de gases de efecto invernadero. Desde 1990, las emisiones de gases de efecto invernadero han aumentado casi un $50 \%$. 
En 2012, los ecosistemas protegidos cubrían el 14\% de las áreas terrestres y marítimas de todo el mundo. Desde 1990, más de 2.300 millones de personas han logrado acceder a una fuente mejorada de agua potable, pero todavía hay 748 millones de personas que obtienen su agua de una fuente no mejorada. Entre 1990 y 2012, casi 2.000 millones de personas lograron acceder a instalaciones sanitarias mejoradas. Sin embargo, 1.000 millones de personas todavía defecan al aire libre. Un tercio de los residentes urbanos de las regiones en desarrollo vive todavía en tugurios. (ODM, 2014)

\subsection{La Constitución Verde de Colombia, 1991}

Colombia permaneció con la Constitución Política de 1886 por un lapso de 105 años, aprobada el $1^{\circ}$ de diciembre de 1885 y expedida el 4 de agosto de 1886; dentro su cuerpo se evidencia que en el artículo 19 consagra que "Las autoridades de la República están instituidas para proteger a todas las personas residente en Colombia, en sus vidas, honra y bienes,....", entendiéndose la vida como un todo y que intrínsecamente conlleva la protección del ambiente y de los recursos naturales renovables.; en su artículo $76 \mathrm{~N}^{\circ} 22$ enuncia sobre la regulación o límite de la apropiación o adjudicación de baldíos y el artículo 185 sobre la función de la Asamblea, fomentar por medio de ordenanzas y recursos propios ordenar la apertura de caminos, canales navegables, canalización de ríos y explotación de bosques de propiedad del Departamento.

Respecto de la totalidad de los 210 artículos de la Constitución Política de 1886, se observa la pobreza del componente ambiental en todo su esplendor material, a diferencia del nutrido contenido ambiental consagrado en la Constitución Política de 1991, definida por el autor como la "Constitución Verde de Colombia".

La Constitución Política es la norma de normas, es la cabeza de la pirámide jerárquica normativa; es un sol donde no puede existir ninguna reglamentación que vaya en contravía que le sustraiga el brillo y luminosidad; si existiesen leyes o decretos contrarios a su esencia, mandatos y preceptos, estaríamos hablando de inexequibilidad e inconstitucionalidad.

La Constitución Política de un país es la norma fundamental de la cual derivan su validez las demás normas positivas; comprende las reglas de juego para la organización del Estado, así como los principios fundamentales para el ejercicio de los derechos y las garantías dentro de ese Estado. Como ha sido aceptado, toda Constitución lleva implícita una filosofía política que sirve de orientación no solamente a los agentes del poder o gobernantes, sino a 
la conducta de los gobernados, en cuantos miembros activos del conglomerado social. (Naranjo, 1995, pp. 354 y 355)

La Corte Constitucional mediante sentencia C-058 de 1994, se refirió en este texto a la Constitución Ecológica y el derecho al ambiente sano, de la siguiente manera:

La protección del medio ambiente ocupa un lugar tan trascendental en el ordenamiento jurídico que la Constitución contiene una "Constitución ecológica", conformada por todas aquellas disposiciones que regulan la relación de la sociedad con la naturaleza y que buscan proteger el medio ambiente. (Colombia, Sentencia, 1994)

Ahora bien, es trascendental partir de lo puntualizado en el Preámbulo Constitucional, en el cual se promulga la Constitución Política con el fin de asegurar a sus integrantes la vida, punto de encuentro con la planificación del manejo y aprovechamiento de los recursos naturales, para garantizar su desarrollo sostenible; bajo éste enfoque y frente a la revisión de la planificación ambiental en la Constitución Política, analizaremos el tema de acuerdo a los trece (13) títulos y 380 artículos dentro de la estructura de la Carta Magna, así:

\subsubsection{Título I. De Los Principios Fundamentales. Art. 1 - 10}

En este sentido, queda claro el motivo de iniciar el análisis normativo ambiental por el Estatuto Constitucional de 1991, siendo pertinente partir con los fines primarios del Estado, consagrados en el artículo $2^{\circ}$ de la Constitución Política, donde se afirma que:

Son fines esenciales del Estado: Servir a la comunidad, promover la prosperidad general y garantizar la efectividad de los principios, derechos y deberes consagrados en la Constitución; facilitar la participación de todos en las decisiones que los afectan y en la vida económica, política, administrativa y cultural de la Nación; defender la independencia nacional, mantener la integridad territorial y asegurar la convivencia pacífica y la vigencia de un orden justo. Las autoridades de la República están instituidas para proteger a todas las personas residentes en Colombia, en su vida, honra, bienes, creencias, y demás derechos y libertades, y para asegurar el cumplimiento de los deberes sociales del Estado y de los particulares. (Fundación especializada en sistemas y servicios, 2013, p. 10)

Del análisis de este artículo, se observan intrínsecamente varios postulados ambientales, el primero al enunciar que todas las personas pueden participar en las decisiones que los afectan, 
verbi gracia, una obra o proyecto que puedan tener impacto ambiental, cualquier persona sin tener un interés directo puede intervenir ante la autoridad ambiental con el fin de proteger los recursos naturales renovables; el anterior precepto fue desarrollado en la ley 99 de 1993, al precisar la figura de tercero interviniente.

Así mismo, el artículo $2^{\circ}$ Constitucional sobre los fines esenciales, se enmarca la integridad territorial por parte del Estado dentro de un marco jurídico que garantice un orden social justo, en armonía con lo que preceptuaba el artículo 19 de la Constitución de 1886.

Además téngase en cuenta el contenido del artículo $8^{\circ}$ (Constitución Política, 1991), el cual puntualiza que: "Es obligación del Estado y de las personas proteger las riquezas culturales y naturales de la Nación”. Es vinculante el presente mandato Constitucional y resalta importancia en afirmar la obligación de proteger, conservar y cuidar la naturaleza tanto a las entidades que representan al Estado y a las personas naturales y jurídicas sin ninguna clase de distinción.

En armonía con el fin de la presente investigación, es la piedra angular Constitucional, la obligación de proteger las riquezas naturales por parte de las personas jurídicas en la reglamentación de la responsabilidad empresarial ambiental.

\subsubsection{Título II. De Los Derechos, Las Garantías Y Los Deberes. Art. 11 - 95}

Bajo el mismo hilo conductor el artículo 49 de la Constitución Política (1991), modificado por el artículo $1^{\circ}$ del acto legislativo 2 de 2009, puntualizó que:

La atención de la salud y el saneamiento ambiental son servicios públicos a cargo del Estado. Se garantiza a todas las personas el acceso a los servicios de promoción, protección y recuperación de la salud. Corresponde al Estado organizar, dirigir y reglamentar la prestación de servicios de salud a los habitantes y de saneamiento ambiental conforme a los principios de eficiencia, universalidad y solidaridad.

Es pertinente ampliar el alcance de este precepto en materia ambiental como obligación esencial del Estado, ya que precisa que el saneamiento ambiental es un servicio público bajo la tutela Estatal y es un objetivo fundamental la solución de estas necesidades como prioridad del gasto público social de acuerdo a lo preceptuado en el artículo $366 \mathrm{CP}$. 
El saneamiento ambiental básico es el conjunto de acciones técnicas y socioeconómicas Saneamiento básico: conjunto de acciones técnicas y socioeconómicas de salud pública que tienen por objetivo alcanzar niveles crecientes de salubridad ambiental. Comprende el manejo sanitario del agua potable, las aguas residuales, los residuos orgánicos, tales como las excretas y residuos alimenticios, los residuos sólidos y el comportamiento higiénico que reduce los riesgos para la salud y previene la contaminación. Tiene por finalidad la promoción y el mejoramiento de condiciones de vida urbana y rural. (CORNARE, 2013)

Es claro en precisar que hasta el día de hoy no todos los municipios de Colombia cuentan con saneamiento ambiental, siendo una responsabilidad Constitucional a cargo del Estado y su falta de cobertura urbana o rural, conlleva a afectaciones ambientales dejando como responsable directo al Estado por su omisión.

De otra parte, entramos al campo de la propiedad privada, los derechos adquiridos, el interés general, la utilidad pública y la función ecológica; al respecto el artículo 58 (Constitución Política, 1991) precisó que:

Se garantizan la propiedad privada y los demás derechos adquiridos con arreglo a las leyes civiles, los cuales no pueden ser desconocidos ni vulnerados por leyes posteriores. Cuando de la aplicación de una ley expedida por motivos de utilidad pública o interés social, resultaren en conflicto los derechos de los particulares con la necesidad por ella reconocida, el interés privado deberá ceder al interés público o social. La propiedad es una función social que implica obligaciones. Como tal, le es inherente una función ecológica.

Es oportuno mencionar que el suscrito radicó demanda de inconstitucionalidad contra el artículo 13 parcial de la ley $2^{\mathrm{a}}$ de 1959. Las razones por las cuales la anterior norma Constitucional fue demandada, radica en: La expresión acusada, es violatorio al derecho de igualdad y el respeto a la propiedad privada y demás derechos adquiridos, al libre ejercicio de enajenabilidad, restricción violatoria a la circulación de los bienes inmuebles ubicados dentro los Parques Nacionales Naturales; así se desprende del tenor del artículo $13^{\circ}$ de la ley $2^{\text {a }}$ de 1959 , en donde se puntualiza la prohibición de ventas de tierras dentro de los Parques Nacionales Naturales.

Propicio aseverar, que cuando la administración declara, reserva y delimita un área para el Sistema de Parques Nacionales Naturales, dentro de sus límites no sólo comprenden predios 
de propiedad Estatal, sino de propiedad privada y pueden quedar incluidos bienes de uso público, bienes baldíos, bienes fiscales propiamente dichos, bienes de propiedad privada individual o colectiva, recursos naturales renovables, y todos estos bienes y valores quedan afectados y destinados al cumplimiento de las finalidades de conservación, perpetuación y protección previstas y descritas en el artículo 328 del decreto ley 2811 de 1974.

Patentizándose una afectación amparada en la ley de Parques Nacionales al núcleo esencial del derecho de propiedad, entendido que la propiedad consta de tres atributos y a falta de uno de ellos deja de ser propiedad (Derecho al goce y frutos - Ius fruendi, Derecho a la disposición - Ius abutendi y el Derecho al uso sobre la cosa - Ius utendi); y, compenetrándose en una ocupación de hecho en los respectivos inmuebles, los cuales deben ser adquiridos mediante compra o expropiación por parte del Estado.

No sobra acotar, que los recursos naturales renovables pertenecen al Estado, sin perjuicio, con arreglo a las leyes, de los derechos adquiridos por particulares. Esta titularidad tiene fundamento en los artículos 8, 63, 79 inciso 2, 80, 102, 330, parágrafo, de la Constitución. Con fundamento en dicha titularidad es que el Estado puede establecer reservas para el manejo, conservación, preservación y restauración de los recursos naturales renovables, o de baldíos, con el fin de destinarlos a satisfacer diferentes necesidades de interés público y social.

Frente al planteamiento expuesto, mediante sentencia C-189 de 2006 la honorable Corte Constitucional, afirmó que:

La propiedad privada ha sido reconocida por esta corporación como un derecho subjetivo al que le son inherentes unas funciones sociales y ecológicas, dirigidas a asegurar el cumplimiento de varios deberes Constitucionales, entre los cuales, se destacan la protección del medio ambiente.... Para lograr el desarrollo sostenible se ha admitido por la jurisprudencia de esta Corporación, que a partir de la función ecológica que establece la Constitución Política en el artículo 58, se puedan imponer por el legislador límites o condiciones que restrinjan el ejercicio de los atributos de la propiedad privada, siempre y cuando dichas restricciones sean razonables y proporcionadas de modo que no afecten el núcleo esencial del citado derecho.

De acuerdo con lo expuesto y teniendo como fundamento la Constitución Política de 1991, es claro que puede definirse a la propiedad privada como el derecho real que se tiene por 
excelencia sobre una cosa corporal o incorporal, que faculta a su titular para usar, gozar, explotar y disponer de ella, siempre y cuando a través de su uso se realicen las funciones sociales y ecológicas que le son propias. Por lo que respecta a la función ecológica de la propiedad, puede afirmarse que su consagración Constitucional constituye una novedosa respuesta del constituyente a la problemática planteada por la explotación y uso indiscriminado de los bienes y derechos particulares en contra de la preservación del medio ambiente sano, considerado como un derecho y bien colectivo en cuya protección debe estar comprometida la sociedad entera (C.P., arts. 79 y 80).

En este contexto, como lo ha reconocido esta corporación, con la introducción de la citada función ecológica se ha incorporado una concepción del ambiente como límite para el ejercicio de los atributos de la propiedad privada, propiciando lo que este tribunal ha denominado como "ECOLOGIZACIÓN DE LA PROPIEDAD”.

Al respecto, en Sentencia C-126 de 1998, la Corte señaló: Ahora bien, en la época actual, se ha producido una "ecologización" de la propiedad privada, lo cual tiene notables consecuencias, ya que el propietario individual no solo debe respetar los derechos de los miembros de la sociedad de la cual hace parte (función social de la propiedad) sino que incluso sus facultades se ven limitadas por los derechos de quienes aún no han nacido, esto es, de las generaciones futuras, conforme a la función ecológica de la propiedad y a la idea del desarrollo sostenible. Por ello el ordenamiento puede imponer incluso mayores restricciones a la apropiación de los recursos naturales o a las facultades de los propietarios de los mismos, con lo cual la noción misma de propiedad privada sufre importantes cambios. (Mantilla L. , 2006)

Lo precedente ha sido sostenido por la Corte Constitucional frente al artículo 58 de la Constitución Política en armonía con el derecho de la propiedad privada y la función ecológica de la misma, observándose que existe una propiedad privada relativa y no absoluta, y que el interés general ambiental prima sobre el interés particular, pero no es suficiente, cada día continúan las afectaciones ambientales y la disminución de la calidad de vida; y sumado a los interés políticos que vende sus cargos temporales por ser cómplices de las infracciones ambientales. Ya no es un problema de futuro, es un problema del presente, no pensar en las generaciones futuras, es pensar en la sobrevivencia actual. 
El artículo 63 de la Carta Constitucional, precisa que "Los bienes de uso público, los parques naturales, las tierras comunales de grupos étnicos, las tierras de resguardo, el patrimonio arqueológico de la Nación y los demás bienes que determine la ley, son inalienables, imprescriptibles e inembargables". El postulado anterior, tiene su fundamento en darle protección a los bienes de uso público y a los parques naturales entre otros, con la finalidad de que los bienes que tienen una propiedad que benefician al conglomerado jamás puedan ser adquiridos por un particular y estos bienes, entre otras funciones brindan espacios verdes, corredores ecológicos, franjas de protección, etc., prestando y generando servicios ambientales.

La Carta Constitucional de 1991, incluye que "Las disposiciones que se dicten en materia crediticia podrán reglamentar las condiciones especiales del crédito agropecuario, teniendo en cuenta los ciclos de las cosechas y de los precios, como también los riesgos inherentes a la actividad y las calamidades ambientales", afirmado por el artículo 66 Constitucional y se habla por primera vez de la calamidades ambientales en materia crediticia, poco avance al respecto.

El artículo 67 Constitucional incluye un nuevo elemento a la educación y es el respeto a la protección del ambiente, así:

La educación es un derecho de la persona y un servicio público que tiene una función social; con ella se busca el acceso al conocimiento, a la ciencia, a la técnica, y a los demás bienes y valores de la cultura. La educación formará al Colombiano en el respeto a los derechos humanos, a la paz y a la democracia; y en la práctica del trabajo y la recreación, para el mejoramiento cultural, científico, tecnológico y para la protección del ambiente. (Constitución Política, 1991)

Frente a este tema, el espíritu normativo es excelente pero su aplicación no; es preciso afirmar que la educación como derecho de las personas busca formar a seres humanos con conciencia ambientalista, evidenciando que en muchos colegios o universidades este tema es irrelevante, en el mejor de los casos tiene la asignatura ambiental, y la utilizan para recoger residuos sólidos en los establecimientos educativos, perdiéndose la esencia que es concienciar en el respeto de las riquezas naturales y formar al estudiante con criterios de que los recursos naturales renovables son sinónimos de vida. Se recomienda realizar una revolución de investigación educativa ambiental. 
Y es donde se le da el carácter de derecho fundamental al derecho a un ambiente sano en conexidad con la vida, fundamentado en el artículo 79 de la norma Constitucional, en cuanto al afirmarse que:

Todas las personas tienen derecho a gozar de un ambiente sano. La ley garantizará la participación de la comunidad en las decisiones que puedan afectarlo. Es deber del Estado proteger la diversidad e integridad del ambiente, conservar las áreas de especial importancia ecológica y fomentar la educación para el logro de estos fines.

Vital este mandato Constitucional, retomado en diferentes fallos judiciales, entre ellos la sentencia T - 444 de 1993 de la Corte Constitucional, que afirmó:

El derecho a gozar de un ambiente sano, es un derecho colectivo, cuya protección se logra a través de las llamadas acciones populares. No obstante, cuando la violación del derecho a gozar de un ambiente sano, implica la violación de otro derecho fundamental (salud, vida e integridad física, entre otros) la acción de tutela es procedente, como mecanismo de protección directa del derecho fundamental, e indirecta del ambiente. (Colombia, Sentencia, 1993)

En el caso de marras y de forma omnímoda con el tema del derecho de todas las personas a gozar de un ambiente sano (artículo $79 \mathrm{CP}$ ) como derecho fundamental, la sentencia T-257 de 1996 de la Corte Constitucional, manifestó que:

La conservación y protección del ambiente, en cuanto tienden a asegurar la salud y la vida y la disponibilidad y oferta constante de elementos ambientales a las generaciones presentes y futuras, constituyen un cometido esencial del Estado. DERECHOS FUNDAMENTALESProtección en asuntos ambientales. Si con la acción o la omisión de las autoridades públicas, o de los particulares, encargados de la prestación de un servicio público o que coloquen en Estado de subordinación o indefensión a las personas o cuya conducta afecte grave y directamente el interés colectivo, se vulneran o amenazan los derechos a la vida o a la salud u otros derechos fundamentales, es procedente la acción de tutela. (Colombia, Sentencia, 1996)

Loable de igual manera precisar, lo expuesto en el artículo $79 \mathrm{CP}$, frente a que la ley debe garantizar la participación de la comunidad en las decisiones que puedan afectarlos, postulado desarrollado en la ley 99 de 1993, justamente en su artículo 69 respecto a la figura de "tercero 
interviniente"; que es la facultad que tiene toda persona en intervenir, reponer, interponerse en todas las actuaciones y trámites ambientales sin necesidad de tener un interés jurídico directo en el tema.

Soslayar el incumplimiento del deber del Estado de proteger la diversidad e integridad del ambiente, conservar las áreas de especial importancia ecológica y fomentar la educación ambiental como mandamiento Constitucional (art. 79 CP); lo precedente, como función delegada a las diferentes autoridades ambientales como entidades del Estado.

Son diferentes los postulados ambientales consignados en nuestra Constitución Política, pero es pertinente centrar la atención en el siguiente precepto (art. $80 \mathrm{CP}$ ), como base primordial de la presente investigación por su esencia y finalidad que persigue, así:

El Estado planificará el manejo y aprovechamiento de los recursos naturales, para garantizar su desarrollo sostenible, su conservación, restauración o sustitución. Además, deberá prevenir y controlar los factores de deterioro ambiental, imponer las sanciones legales y exigir la reparación de los daños causados. Así mismo, cooperará con otras naciones en la protección de los ecosistemas situados en las zonas fronterizas. (Constitución Política, 1991)

Paráfrasis al anterior precepto Constitucional y objeto de esta investigación, es la estructura impuesta al Estado en armonía con lo ratificado en la declaración de Estocolmo de 1972, en donde, las entidades gubernamentales ambientales tienen las siguientes competencias vinculantes e incluyendo el Estado Colombiano, así:

1. El Estado planificará el manejo y aprovechamiento de los recursos naturales:

Es saber con qué cuenta el país frente a los recursos naturales renovables, verbi gracia: El recurso hídrico (aguas superficiales y subterráneas), qué tenemos y en qué estado (estudios hidrogeológico, hídricos, calidad del agua, entre otros), cuánto caudal tenemos (metro cubico), hasta cuándo nos alcanza, cuántas personas lo necesitan, para qué uso, para consumo humano, industrial o agropecuario.

En este sentido, poder planear su manejo y aprovechamiento, evitando y enfrentando las sequías en el país, en cara a los diferentes fenómenos climáticos atípicos y previamente realizar 
la ordenación de las cuencas hidrográficas, seguido, cumplir con la distribución del caudal dando prioridad al consumo humano, entre otras concesiones; garantizando un caudal ecológico en armonía con el desarrollo sostenible moderno.

1. Garantizar su desarrollo sostenible, su conservación, restauración o sustitución. Finalidad esencial del Estado, ligada a asegurar a sus integrantes la vida humana, en avenencia con lo dispuesto en el preámbulo Constitucional.

2. Prevenir y controlar los factores de deterioro ambiental

3. Imponer las sanciones legales y

4. Exigir la reparación de los daños causados.

A demás de lo expuesto, resulta igualmente diáfano afirmar que este precepto Constitucional tiene un amplio alcance en pro de los recursos naturales renovables, partiendo de la efectiva planificación ambiental como medida vinculante para el Estado y en salvaguarda de la vida propia. Conceptos y propuesta de reglamentación legal que ampliaremos su análisis en el capítulo tercero de la presente investigación.

Continuando con el recorrido Constitucional ambiental, llegamos a lo dispuesto en el artículo 81 que prohíbe el ingreso a Colombia de residuos nucleares y desechos tóxicos, siendo considerados como residuos altamente peligrosos para la vida, por su alto grado de componentes químicos (tóxicos), que pueden conllevar a la contaminación ambiental y humana; restricción enmarcada en la responsabilidad ambiental del Estado, así:

Queda prohibida la introducción al territorio nacional de residuos nucleares y desechos tóxicos. El Estado regulará el ingreso al país y la salida de él de los recursos genéticos, y su utilización, de acuerdo con el interés nacional.

Así mismo, el artículo 82 trae un grado de similitud con lo dispuesto en el artículo 58 de la Carta Constitucional, referente al interés general e interés común, incluyendo un componente novedoso en la presente investigación, como es el uso del suelo y el espacio público, así:

Es deber del Estado velar por la protección de la integridad del espacio público y por su destinación al uso común, el cual prevalece sobre el interés particular. Las entidades públicas participarán en la plusvalía que genere su acción urbanística y regularán la utilización del suelo y del espacio aéreo urbano en defensa del interés común. 
Este artículo lo que denota, es, precisamente que el suelo es un componente de regulación, funciones dadas a los concejos municipales, los cuales a través de acuerdos municipales pueden definir o regular los uso del suelo, entre ellos, el suelo de protección u conservación ambiental. Trasparente al afirmar que los POT, EOT, PBOT son instrumentos de ordenamiento territorial, pero no de los recursos naturales renovables.

No obstante lo anterior, lo más relevante es el ejercicio de los derechos y libertades reconocidos en la Constitución Política implicando responsabilidades para todas las persona la obligación de "Proteger los recursos culturales y naturales del país y velar por la conservación de un ambiente sano" de acuerdo lo preceptuado en el numeral 8 del artículo 95 de la CP.

\subsubsection{Título III. De Los Habitantes Y Del Territorio. Art. 96 - 102}

Es por ello que en palabras de la Constitución Política el artículo 101, afirma que son parte de Colombia, "el subsuelo, el mar territorial, la zona contigua, la plataforma continental, la zona económica exclusiva, el espacio aéreo, el segmento de la órbita geoestacionaria, el espectro electromagnético y el espacio donde actúa”.

Y aunado a lo anterior, el contenido del artículo 102, ratifica que "El territorio, con los bienes públicos que de él forman parte, pertenecen a la Nación". Se refieren estos contenidos, que es propiedad la Nación del subsuelo, el mar, el aire, el territorio; en este sentido, por ser el Estado el propietario de los recursos naturales renovables, conlleva la obligación de planificarlos ambientalmente, en coherencia con lo incluido en el artículo 80 Constitucional.

\subsubsection{Título IV. De La Participación Democrática y Partidos Políticos. Art. 103 - 112}

No aplica el presente título Constitucional para la línea de investigación, por no consagrar en sus artículos contenidos ambientales, ni de planificación sobre el tema. Sin embargo, no es óbice para afirmar que los diferentes partidos políticos promueven el desarrollo económico y consagran dentro de sus estatutos, reglamentos y políticas internas la necesidad como colectividad de realizar la protección y conservar los recursos naturales renovables.

La naturaleza un tema de moda en los diferentes sectores y agremiaciones; y en distintas oportunidades, es el centro o columna vertebral de programas de gobiernos y/o campañas electorales. 


\subsubsection{Título V. De La Organización del Estado. Art. 113 - 131}

En el presente título de la Constitución Política no se enuncian ningún articulado que estén ligado con la planificación en el manejo y aprovechamiento de los recursos naturales como la fauna, flora, agua, aire, entre otros, ni postulados ambientales.

\subsubsection{Título VI. De La Rama Legislativa. Art. 132 - 187}

Requisito obligatorio de raigambre Constitucional, lo dispuesto en el artículo 150 que enuncia las funciones del Congreso de la República y en su numeral séptimo facultó "reglamentar la creación y funcionamiento de las Corporaciones Autónomas Regionales dentro de un régimen de autonomía”, y en armonía con los fallos de la honorable Corte Constitucional, son entidades creadas para la conservación de los recursos naturales renovables y con funciones de autoridad ambiental, como se analizará en el capítulo siguiente, en la materia propia que la contienen.

\subsubsection{Título VII. De La Rama Ejecutiva. Art. 188 - 227}

Al mismo tiempo, acorde con el carácter Constitucional los estados de emergencia, pueden declararse de conformidad con lo dispuesto en el artículo 215 C.P., así:

Cuando sobrevengan hechos que perturben o amenacen perturbar en forma grave $e$ inminente el orden económico, social y ecológico del país, o que constituyan grave calamidad pública, podrá el Presidente, con la firma de todos los ministros, declarar el Estado de Emergencia por períodos hasta de treinta días en cada caso, que sumados no podrán exceder de noventa días en el año calendario. Mediante tal declaración, que deberá ser motivada, podrá el Presidente, con la firma de todos los ministros, dictar decretos con fuerza de ley, destinados exclusivamente a conjurar la crisis y a impedir la extensión de sus efectos. Estos decretos deberán referirse a materias que tengan relación directa y específica con el Estado de emergencia, y podrán, en forma transitoria, establecer nuevos tributos o modificar los existentes.

De este precepto se desprende un deber genérico de actuación por parte del Presidente de la República, que obliga a declarar los Estados de emergencia cuando perturben o puedan perturbar en forma grave el orden ecológico en todo el país; cabría entonces señalar que un Estado de emergencia ambiental puede darse frente a las consecuencias de un grave periodo 
invernal, y uno de ellos fue el decretado por el Gobierno Nacional de Colombia mediante el decreto 4580 de 2010 "Por el cual se declara el Estado de emergencia económica, social y ecológica por razón de grave calamidad pública", el cual se fundamentó en que en "Todo el territorio nacional han sobrevenido hechos constitutivos de grave calamidad pública. El fenómeno de La Niña desatado en todo el país, constituye un desastre natural de dimensiones extraordinarias e imprevisibles, el cual se agudizó en forma inusitada e irresistible”. (Colombia, Ministerio del Interior y de Justicia, 2010)

Por lo mismo y en aplicación de lo consagrado en el artículo 226 de la Constitución Política, señala que "El Estado promoverá la internacionalización de las relaciones políticas, económicas, sociales y ecológicas sobre bases de equidad, reciprocidad y conveniencia nacional." De acuerdo con el recuento trascrito, se observa que la agenda ambiental o ecológico está en las relaciones internacionales como principio soberano; y no es para menos ya que la problemática ambiental es una preocupación de todos los países del mundo, reflejado en las diferentes convenciones, cumbres y tratados internacionales, entre ellas la celebrada en río de janeiro - Brasil, denominada "Rio + 20” (El Futuro que Queremos).

«Rio+20» es el nombre abreviado de la Conferencia de las Naciones Unidas sobre el Desarrollo Sostenible, que tuvo lugar en Río de Janeiro, Brasil ( del 20 al 22 de junio de 2012), veinte años después de la histórica Cumbre de la Tierra en Río en 1992. Río +20 fue también una oportunidad para mirar hacia el mundo que queremos tener en 20 años.

En la Conferencia Río +20 , los líderes mundiales, junto con miles de participantes del sector privado, las ONG y otros grupos, se unieron para dar forma a la manera en que puede reducir la pobreza, fomentar la equidad social y garantizar la protección del medio ambiente en un planeta cada vez más poblado. Las conversaciones oficiales se centraron en dos temas principales: cómo construir una economía ecológica para lograr el desarrollo sostenible y sacar a la gente de la pobreza, y cómo mejorar la coordinación internacional para el desarrollo sostenible. (ONU, 2012)

\subsubsection{Título VIII. De La Rama Judicial. Art. 228 - 257}

Dubitativa interpretación en afirmar que en el presente título Constitucional no se enuncian postulados ambientales, sin desconocer que los artículos 234, 236, 239 y 249 de la Carta Política, hacen referencia a la Jurisdicción Ordinaria, Contenciosa Administrativa, 
Constitucional y de la Fiscalía General de la Nación; y son allí en la vía litigiosa donde pueden hacerse efectivo el derecho a un ambiente sano de las personas en conexidad con la vida, sea por nulidad de un acto administrativo que atente contra la naturaleza, un delito penal ambiental, la aplicación de los medios de control como mecanismo de defensa para los recursos naturales renovables.

Para atender los validos planteamientos Constitucionales ambientales, afirmamos que los recursos naturales renovables tienen sus herramientas de defensa y salvaguarda, es decir los dientes que permiten que este consolidado ambiental sea una realidad; estamos hablando de la artillería jurídica Constitucional como mecanismos de participación y defensa ciudadana, y es en este sentido que la Corte Constitucional mediante sentencia C-423 de 1994, ratificó que:

En cuanto a la implementación de mecanismos judiciales de preservación o de sanción, debe decirse que tanto la Constitución como la ley consagran diferentes acciones tendientes a cumplir con algunos de estos fines. A manera de ejemplo conviene señalar que el artículo 88 superior consagra las denominadas acciones populares, encaminadas a la protección de los derechos e intereses colectivos como es el caso del ambiente. Nótese que esta disposición trata al ambiente como un derecho colectivo, es decir, se refiere a un sujeto universal donde cualquier persona tiene legitimación en la causa para solicitar ante el juez la protección de ese bien común.

De igual forma, no sobra agregar que, de conformidad con la jurisprudencia de esta Corporación Constitucional, la acción de tutela consagrada en el artículo 86, se constituye en un mecanismo de protección cuando la violación al ambiente implique de manera directa la vulneración de algún derecho Constitucional fundamental. En cuanto a los mecanismos legales pertinentes, basta con mencionar a las acciones populares consagradas en el Código Civil, a los delitos previstos en el Código Penal o a las sanciones pecuniarias establecidas en el Código de Recursos Naturales. (Colombia, Sentencia, 1994),

Aunado a lo precedente, complementaria con afirmar que existe otros mecanismos Constitucionales en aras de velar por el cumplimiento a la obligación Estatal Constitucional de planificar el manejo y aprovechamiento de los recursos naturales para garantizar su desarrollo sostenible; estamos hablando del derecho fundamental de petición (artículo 23), la acción de cumplimiento (artículo 87 CP), la acción popular y de grupo (artículo 88 CP, ley 472 de 1998), el 
medio de control de reparación directa por responsabilidad extracontractual del Estado (artículo 90 CP), medio de control nulidad propiamente dicha (ley 1437 de 2011, artículo 137), demanda de controversias contractuales, demanda de nulidad y restablecimiento del derecho (ley 1437 de 2011, artículo 138) y la figura del tercero interviniente, definida como "el derecho de cualquier persona natural o jurídica o privada, sin necesidad de demostrar interés jurídico alguno, podrá intervenir en las actuaciones administrativas que afecten o puedan afectar el medio ambiente" (artículo 69 ley 99 de 1993), entre otras.

\subsubsection{Título IX. De Las Elecciones Y De La Organización Electoral. Art. 258 - 266}

No aplica el presente título para la línea de investigación, por no consagrar contenidos ambientales, ni de planificación sobre el tema.

\subsubsection{Título X. De Los Organismos De Control. Art. 267 - 284}

El numeral $7^{\circ}$ del artículo $268 \mathrm{CP}$, puntualiza que el Contralor General de la República tendrá entre otras, la siguiente atribución: "Presentar al Congreso de la República un informe anual sobre el Estado de los recursos naturales y del ambiente". En consecuencia una primera inferencia obvia que resulta del texto trascrito es que la Contraloría General de la República tiene que realizar un estudio y seguimiento a las autoridades ambientales, con el fin de rendir este informe anual sobre el Estado de los recursos naturales; tema que ampliaremos en el capítulo siguiente de las autoridades ambientales.

En este mismo sentido, corresponde al Procurador General de la Nación, por sí o por medio de sus delegados y agentes, ejercer dentro de sus funciones como órgano de control disciplinario "Defender los intereses colectivos, en especial el ambiente", con fundamento en el numeral 4 del artículo 277 Constitucional. Abordaremos su análisis en el capítulo segundo de la presente investigación.

Según la Constitución Política, en el artículo 282, numerales $1^{\circ}$ y $5^{\circ}$, determina que es función del Defensor del Pueblo, Orientar e instruir a los habitantes del territorio nacional y a los Colombianos en el exterior en el ejercicio y defensa de sus derechos ante las autoridades competentes o entidades de carácter privado e Interponer acciones populares en asuntos relacionados con su competencia, y el derecho que tienen todas las personas a un ambiente sano 
por mandato Constitucional se encuentra clasificado dentro de los derechos colectivos y del ambiente, por ende las acciones populares radicadas por la defensoría del pueblo es un instrumento muy valioso de defensa para proteger los recursos naturales renovables.

\subsubsection{Título XI. De La Organización Territorial. Art. 285 - 331}

De otra parte, el artículo 289 Constitucional enuncia que "los departamentos y municipios ubicados en zonas fronterizas podrán adelantar directamente con la entidad territorial limítrofe del país vecino, programas de cooperación e integración, dirigidos a fomentar el desarrollo comunitario, la prestación de servicios públicos y la preservación del ambiente”. Coherente con el tema materia de estudio, ya que la protección y conservación ambiental, no tiene barreras, el ambiente es universal libre, sin límites de los Estados, es único, es la vida; de ahí radica la importancia de este axioma; en donde los departamentos y municipios puedan adelantar programas de cooperación, articulación y gestión para la preservación ambiental con el país vecino, en busca de proteger los ecosistemas limítrofes binacional.

Es indudable, en consecuencia al legislativo departamental le asignó la Constitución Política la función de "Expedir las disposiciones relacionadas con la planeación, el desarrollo económico y social,... el turismo, el transporte, el ambiente, las obras públicas, las vías de comunicación y el desarrollo de sus zonas de frontera"; al efectuar análisis del caso de marras tenemos que las Asambleas Departamentales, les compete por medio de ordenanzas trabajar temas relacionados con el ambiente. El precedente tema ambiental de las asambleas departamentales contemplado en el artículo 300 numeral $2^{\circ}$ Constitucional, lo abordaremos con mayor profundidad en el capítulo de las autoridades ambientales.

De otra parte, existen departamentos que tienen una especial protección por sus riquezas culturales y naturales, por ende rememoro lo dispuesto en el artículo 310 del Estatuto Constitucional, que afirma:

El Departamento Archipiélago de San Andrés, Providencia y Santa Catalina se regirán, además de las normas previstas en la Constitución y las leyes para los otros departamentos, por las normas especiales que en materia administrativa, de inmigración, fiscal, de comercio exterior, de cambios, financiera y de fomento económico establezca el legislador. Mediante ley aprobada por la mayoría de los miembros de cada cámara se podrá limitar el 
ejercicio de los derechos de circulación y residencia, establecer controles a la densidad de la población, regular el uso del suelo y someter a condiciones especiales la enajenación de bienes inmuebles con el fin de proteger la identidad cultural de las comunidades nativas y preservar el ambiente y los recursos naturales del Archipiélago. (Constitución Política, 1991)

Para hacer referencia a lo trascrito, debe decirse que el departamento archipiélago de San Andrés, providencia y santa catalina tiene una connotación Constitucional especial con el fin, entre otros de proteger y conservar el ambiente y lo recursos naturales de éste hermoso lugar, rodeado de riquezas naturales y que cuenta con unas áreas protegidas del orden nacional.

De igual manera, los Concejos municipales, de conformidad con lo contemplado en el numeral 9 del artículo 313 de la CP, poseen facultades para "Dictar las normas necesarias para el control, la preservación y defensa del patrimonio ecológico y cultural del municipio"; lo precedente, en armonía con el principio ambiental del rigor subsidiario pueden proferir diferentes acuerdos municipales en el contexto ambiental en los diferentes componentes, fauna, flora, aire, agua, entre otros y pueden hacer usos del principio de precaución en estos acuerdos para fundamentarlos jurídica y técnicamente enfocados a proteger el patrimonio ecológico municipal. La Corte Constitucional en sentencia C- 243 de 1997, constriñó que:

El objetivo de la disposición acusada no es óbice para que los concejos municipales produzcan la normativa que consideren pertinente para proteger su patrimonio ecológico, siempre que lo hagan atendiendo las limitaciones que les impongan la Constitución y la ley, con lo que se garantiza un manejo coordinado y armónico de temas que trascienden el interés local, lo que quiere decir que no se vacía de contenido la facultad de origen Constitucional.

La prohibición recae sobre situaciones ya previstas en normas jurídicas de carácter ambiental expedidas por el Ministerio del Medio Ambiente, las Corporaciones Autónomas Regionales y los grandes centros urbanos o áreas metropolitanas, esto es sobre asuntos que ya fueron objeto de regulación jurídica por parte de esos organismos, los cuales de conformidad con las disposiciones de la ley 99 de 1993, hacen parte del Sistema Nacional Ambiental, lo que es perfectamente compatible con el mandato de la Constitución Política, que establece que "cuando un derecho o una actividad hayan sido reglamentados de manera 
general, las autoridades públicas no podrán establecer ni exigir permisos, licencias o requisitos adicionales para su ejercicio. (Colombia, Sentencia, 1994)

Ya frente al tema económico, se crea por mandato Constitucional la "Sobretasa Ambiental", que es un porcentaje del impuesto predial, que se destinará para las autoridades ambientales de la región, lo precedente, de acuerdo al contenido del artículo 317 de la Carta Constitucional, al respecto:

Solo los municipios podrán gravar la propiedad inmueble. Lo anterior no obsta para que otras entidades impongan contribución de valorización. La ley destinará un porcentaje de estos tributos, que no podrá exceder del promedio de las sobretasas existentes, a las entidades encargadas del manejo y conservación del ambiente y de los recursos naturales renovables, de acuerdo con los planes de desarrollo de los municipios del área de su jurisdicción.

Raudamente se analiza que, la Constitución Política no preciso puntualmente la institución ambiental que manejaría los recursos proveniente de la sobretasa ambiental, solo preceptúo que a las entidades encargadas del manejo y conservación del ambiente y de los recursos naturales renovables, es decir, aquí se circunscriben las Corporaciones autónomas regionales, las áreas metropolitanas y grandes centros urbanos mayor a un millón de habitantes en su casco urbano y los distritos especiales de acuerdo a su jurisdicción ambiental.

La Constitución Política en su artículo 328, modificado por el artículo $2^{\circ}$ del acto legislativo 2 de 2007, señaló que "El Distrito Turístico y Cultural de Cartagena de Indias, el Distrito Turístico, Cultural e histórico de Santa Marta y Barranquilla conservarán su régimen y carácter, y se organiza a Buenaventura y Tumaco como Distrito Especial, Industrial, Portuario, Biodiverso y Ecoturismo". De lo anterior podemos fácilmente concluir, sin entrar a analizar muy a fondo; simplemente aplicando la lógica y es que los distritos especiales tienen su protección especial por mandato Constitucional y tendrán su propio régimen especial ambiental, y fue el definido mediante la ley 1617 de 2013, que les permite crear establecimientos públicos para ejercer las funciones de autoridad ambiental; lo precedente, por su carácter especial biodiverso y ecoturísticos, entre otros. 
En lo que respecta a los territorios indígenas de acuerdo a lo letrado en el numeral 5 del artículo 330 CP., dentro de sus funciones, se encuentra: "Velar por la preservación de los recursos naturales" y en Parágrafo del mismo Estatuto afirma que:

La explotación de los recursos naturales en los territorios indígenas se hará sin desmedro de la integridad cultural, social y económica de las comunidades indígenas. En las decisiones que se adopten respecto de dicha explotación, el Gobierno propiciará la participación de los representantes de las respectivas comunidades.

En otras palabras, todas las decisiones que puedan afectar los recursos naturales al interior de los territorios indígenas deben hacerse consulta previa, en armonía con el numeral $3^{\circ}$ del artículo $7^{\circ}$ de la ley 21 de 1991, por la cual se aprueba el Convenio № 169 de 1987 de la OIT sobre pueblos indígenas y tribales, dispone que:

Los gobiernos deberán velar porque, siempre que haya lugar, se efectúen estudios, en cooperación con los pueblos interesados, a fin de evaluar la incidencia social, espiritual y cultural y sobre el medio ambiente que las actividades de desarrollo previstas puedan tener sobre esos pueblos. Los resultados de estos estudios deberán ser considerados como criterios fundamentales para la ejecución de las actividades mencionadas".

En este mismo sentido frente a las comunidades indígenas y afro, el artículo 76 de la ley 99 de 1993, se estipula:

Laexplotación delos recursos naturales deberáhacersesin desmedro de la integridad cultural, social y económica de las comunidades indígenas y de las negras tradicionales de acuerdo con la ley 70 de 1993, y las decisiones sobre la materia se tomarán, previa consulta a los representantes de tales comunidades.

Y con el decreto $\mathrm{N}^{\circ} 1320$ de 1998, se reglamentó la consulta previa con las comunidades indígenas y negras para la explotación de los recursos naturales dentro de su territorio; todo lo anterior en desarrollo del artículo 330 del Estatuto Constitucional.

Se requiere, ahora entrar a precisar que la Corporación Autónoma Regional del Río Grande de la Magdalena - Cormagdalena fue creada con soporte Constitucional y organizada por la ley 161 de 1994 "como un ente corporativo especial del orden nacional con autonomía administrativa, presupuestal y financiera, dotado de personería jurídica propia, el cual funcionará 
como una Empresa Industrial y Comercial del Estado" y de conformidad al artículo 331 de la Constitución Política, quedó:

Encargada de la recuperación de la navegación, de la actividad portuaria, la adecuación y la conservación de tierras, la generación y distribución de energía y el aprovechamiento y preservación del ambiente, los recursos ictiológicos y demás recursos naturales renovables.

De la lectura precedente conlleva a señalar que la Corporación Autónoma Regional del Río Grande de la Magdalena - Cormagdalena no es una autoridad ambiental, sino es una empresa industrial y comercial del Estado sometidas a las reglas de las sociedades anónimas, y cuenta con un enfoque de fomento, aprovechamiento y preservación de los recursos naturales con incidencia en el río magdalena.

Así mismo, ha de recordarse el contenido historio de la Constitución Política de 1886, y lo expuesto en el artículo 202, precisa que:

Pertenecen a la República de Colombia (....) 2. Los baldíos, minas y salinas que pertenecían a los Estados cuyo dominio recobra la Nación, sin perjuicio de los derechos constituidos a favor de terceros por dichos Estados o a favor de estos por la Nación a título de indemnización.. 3. Las minas de oro, plata, de platino y de piedras preciosas que existían en el territorio nacional, sin perjuicios de los derechos que por leyes anteriores hayan adquiridos los descubridores y explotadores sobre algunas de ellas.

\subsubsection{Título XII. Del Régimen Económico Y De La Hacienda Pública. Art. 332 - 373}

Sin dejar a un lado lo expuesto anteriormente y de forma sistémica, el nuevo texto Constitucional (1991), en su artículo 332 afirma que el "Estado es propietario del subsuelo y de los recursos naturales no renovables, sin perjuicio de los derechos adquiridos y perfeccionados con arreglo a las leyes preexistentes". Lo expuesto trae consigo para el caso en particular, que el Estado es el propietario del subsuelo y de los recursos naturales no renovables, como el oro, carbón, petróleo, gas natural, agua subterráneas (acuíferos) entre otros minerales y metales; así lo señala la norma de normas, pero vemos que hoy el Estado a través de sus agentes ha entregado las riquezas mineras y petroleras a manos privadas nacionales e internacionales (verbi gracia, títulos mineros) y aún lo más complejo, es que se realiza la explotación minera y petrolera en 
ciertas oportunidades en áreas de conservación y preservación natural, y no se observa la aplicación de la planificación ambiental vinculante para el Estado.

Frente al tema de la minería versus los páramos, agua, flora, suelo y paisaje, es pertinente realizar un análisis de esta situación en toda Colombia dentro del marco de la planificación ambiental; con el agravante que los ecosistemas de páramos No están delimitados (Escala 1:25000) en el territorio nacional salvo el Páramo de Jurisdicciones - Santurban - Berlín en el departamento de Santander y Norte de Santander, que fue adoptado mediante la Resolución $N^{\circ}$ 2090 de diciembre 19 de 2014 proferida por el Ministerio de Ambiente y Desarrollo Sostenible.

Se afirma que existen consecuencias y afectaciones ambientales por la exploración y explotación minera; frente al postulado anterior, tal afirmación es verídica. Situación diferente que puedan minimizarse sus impactos ambientales y que se faculte al Estado a fijar compensaciones ambientales a los titulares de las licencias ambientales y títulos o contratos de concesión minera al respecto; de aquí la importancia de verificar por las autoridades ambientales el cumplimiento a las obligaciones de mitigación, restauración y compensación fijados a las empresas mineras. A su vez, la disposición Constitucional contemplada en el artículo 333 puntualiza que:

La actividad económica y la iniciativa privada son libres, dentro de los límites del bien común. Para su ejercicio, nadie podrá exigir permisos previos ni requisitos, sin autorización de la ley. La libre competencia económica es un derecho de todos que supone responsabilidades. La empresa, como base del desarrollo, tiene una función social que implica obligaciones. El Estado fortalecerá las organizaciones solidarias y estimulará el desarrollo empresarial... La ley delimitará el alcance de la libertad económica cuando así lo exijan el interés social, el ambiente y el patrimonio cultural de la Nación. (Constitución Politica, 1991)

Ahora es evidente que no tendría sentido la existencia de un derecho si Constitucionalmente no hubiese los medios o mecanismos para su concreción y ante todo para garantizar su efectividad y es donde la Corte Constitucional en reiterados pronunciamientos ha sido contundente en afirmar que la empresa está en total libertad, pero debe cumplir una función social y ecológica; podríamos denominar que es la base Constitucional para la "responsabilidad 
social ambiental empresarial - RSAE" y ligada a la obligación del Estado de realizar la planificación ambiental, así:

Estas normas se refieren a que el Estado planificará el manejo y aprovechamiento de los recursos naturales para garantizar su desarrollo sostenible, su conservación, restauración o sustitución, y además deberá prevenir y controlar los factores de deterioro ambiental (C.P. Art. 80); y a que el Estado intervendrá en la explotación de los recursos naturales, con el fin de conseguir la preservación de un ambiente sano. (C.P Art. 334). (Colombia, Sentencia, 2009)

Así las cosas, la Corte Constitucional mediante sentencia C- 263 de 2011, concluye que la exégesis literal de las libertades económicas, deben tener unos criterios para evaluar la razonabilidad y proporcionalidad de una medida limitante, así:

Respecto de cómo evaluar la razonabilidad y proporcionalidad de una medida que limita las libertades económicas, la Corte ha indicado que: en primer lugar, el Legislador debe tener en cuenta el tipo de actividad que desarrollan las empresas a las que va dirigida la regulación, su estructura organizativa, el mercado en el que se insertan, el tipo de financiamiento al que apelan, el servicio que prestan o el bien que producen o distribuyen, etc.; y en segundo lugar, se apela al juicio de proporcionalidad, mediante el cual se examina la finalidad de la medida, la idoneidad del medio elegido y su proporcionalidad en estricto sentido. (Colombia, Sentencia, 2011)

La actividad económica y la iniciativa privada son libres, dentro de los límites del bien común; se observa una contradicción en afirmar el constituyente que es libre la actividad económica, porque a reglón seguido, se afirma que tiene sus límites en el bien común, ósea la actividad económica y la iniciativa privada no son tan libre porque tiene una limitante "el bien común ambiental”.

Seguido, se entiende que el bien común es armónico con el interés general, que prima sobre el particular; y este bien común incluye el ambiente que va ligado con la salud, la integridad y la vida. En este sentido, la actividad económica e iniciativa privada debe tener su desarrollo dentro del límite y respeto a la protección de los recursos naturales renovables, como derecho superior Constitucional. 
En igual sentido precisa el artículo $333 \mathrm{CP}$, que la libre competencia económica es un derecho de todos que supone responsabilidades; y así mismo, la empresa como base y motor del desarrollo, tiene una función social que implica obligaciones. Estas responsabilidades y obligaciones no son otras diferentes a lo que hemos tratado, y es entre otras, el respeto a los recursos naturales renovables, al ambiente, a la vida, a tener cada empresa un enfoque dentro de la responsabilidad social ambiental empresarial - RSAE.

Por último, la norma Constitucional precisa que "La ley delimitará el alcance de la libertad económica cuando así lo exijan el interés social, y el ambiente"; es aquí donde analizaremos en el siguiente capítulo, si este precepto Constitucional tiene un marco legal reglamentario asignado a las autoridades ambientales nacional, regional y local.

Ahora bien, una interpretación sistemática o contextual del artículo 334 CP, modificado por el artículo $1^{\circ}$ del acto legislativo 3 de 2011, precisa que:

La dirección general de la economía estará a cargo del Estado. Este intervendrá, por mandato de la ley, en la explotación de los recursos naturales, en el uso del suelo, en la producción, distribución, utilización y consumo de los bienes, y en los servicios públicos y privados, para racionalizar la economía con el fin de conseguir en el plano nacional y territorial, en un marco de sostenibilidad fiscal, el mejoramiento de la calidad de vida de los habitantes, la distribución equitativa de las oportunidades y los beneficios del desarrollo y la preservación de un ambiente sano. Dicho marco de sostenibilidad fiscal deberá fungir como instrumento para alcanzar de manera progresiva los objetivos del Estado Social de Derecho.

Se observa un artículo Constitucional intervencionista dentro de un escenario o contexto ambientalista en busca de preservar el derecho que tienen todas las personas a un ambiente sano, y enfocados a la realización de los fines esenciales del Estado social de derecho; y es así como se refirió en este texto en los siguientes términos:

El Estado interviene en la explotación de los recursos naturales. Su poder interventor sobre la economía busca, entre otras finalidades, la preservación del ambiente sano. Se trata de garantizar el derecho colectivo previsto en el artículo 79 de la Carta, a través de los mecanismos intervencionistas de la economía. 
Si hay algún artículo de la Constitución Política de 1991 que deba tenerse en cuenta para su consideración como Constitución Ecológica, es el 334. Dentro de los grandes objetivos que se establecieron para la intervención del Estado en la economía, se incluyó el de la preservación de un ambiente sano, junto con los de racionalizar la economía con el fin de conseguir el mejoramiento de la calidad de vida de los habitantes, y, por otro lado, la distribución equitativa de las oportunidades y los beneficios del desarrollo. (Amaya, 2002, pp. 204 y 205)

Conviene recordar el contenido del artículo $340 \mathrm{CP}$, donde se enuncia la representación del sector ecológico al interior del Consejo Nacional de Planeación, el cual puntualiza que:

Habrá un Consejo Nacional de Planeación integrado por representantes de las entidades territoriales y de los sectores económicos, sociales, ecológicos, comunitarios y culturales. El Consejo tendrá carácter consultivo y servirá de foro para la discusión del Plan Nacional de Desarrollo. En las entidades territoriales habrá también consejos de planeación, según lo determine la ley. El Consejo Nacional y los consejos territoriales de planeación constituyen el Sistema Nacional de Planeación.

Lo anterior, por cuanto responden a la Constitución del sistema nacional de planeación, que se encuentra en la raíz de la transformación de este modelo Estatal participativo y pluralista (art. $1^{\circ} \mathrm{CP}$ ), de ahí su particular relevancia Constitucional, y fue la integración de los diferentes sectores, entre estos el ecológico; si bien es cierto que es formar parte del consejo nacional y los consejos territoriales de planeación con carácter consultivo, tiene su relevancia en poder dirección las potenciales realidades jurídicas a fin de ser incorporados en el plan nacional de desarrollo, que es la Carta de navegación con duración de cuatro años en lo que evolucionará y dinamizará el país.

Por otro lado, el artículo 360 del Estatuto Constitucional fue modificado por el artículo $1^{\circ}$ del acto legislativo 5 de 2011 , el cual señala:

La explotación de un recurso natural no renovable causará, a favor del Estado, una contraprestación económica a título de regalía, sin perjuicio de cualquier otro derecho o compensación que se pacte. La ley determinará las condiciones para la explotación de los recursos naturales no renovables. 
Mediante otra ley, a iniciativa del Gobierno, la ley determinará la distribución, objetivos, fines, administración, ejecución, control, el uso eficiente y la destinación de los ingresos provenientes de la explotación de los recursos naturales no renovables precisando las condiciones de participación de sus beneficiarios. Este conjunto de ingresos, asignaciones, órganos, procedimientos y regulaciones constituye el Sistema General de Regalías.

Lo precedente, encuentra trascendencia con lo previsto en las fuentes de financiación para proyectos locales o regionales con los recursos provenientes del sistema general de regalías, que a hoy, quedo centralizado por el Gobierno Nacional. La esencia es buena en el sentido de distribuir regalías a municipios que no tienen explotación de los recursos naturales no renovables; lo que no se comparte, es que los alcaldes o gobernadores deben ingresar en los allegados a esta cartera a fin obtener financiaciones para su proyectos con estos rubros, sea por gestión propia o a través de los miembros del Congreso de la República, que varios han dejado su papel legislativo para convertirse en gestores de proyectos ante el Gobierno nacional.

Un componente que debe ser materia de análisis jurídico ambiental profundo e íntegro, es la destinación y uso de las regalías, ya que las mismas se obtienen por la explotación de los recursos naturales no renovables, conllevando implícitamente afectación y deterioro a los recursos naturales renovables, llámese agua, fauna, flora, aire; y el porcentaje de estas regalías que se invierten en la recuperación de los propios ecosistemas afectados es mínimo e incipiente y no existe una reglamentación vinculante para las entidades públicas o privadas nacionales o extranjeras que realizan estas explotaciones, a que realicen una efectiva aplicación de política de responsabilidad social ambiental empresarial - RSAE.

No debe desconocerse que cada trámite ambiental sea de licencia ambiental, ocupación de cauce, concesión de agua, permiso de vertimiento, entre otros; todos deben llevar impuesta las compensaciones ambientales de ley que son las obligadas a recuperar lo deteriorado; si existiese la planificación ambiental, se obligaría a que estas compensaciones se realizarán para recuperar franjas, corredores, parques o espacios ecológicos al servicio de las comunidades que reciben el impacto ambiental, pensando en un futuro sostenible.

En este mismo sentido el artículo 361 de la Constitución Política, fue modificado por el artículo $1^{\circ}$ del acto legislativo 5 de 2011, el cual se definió, así: 
Los ingresos del Sistema General de Regalías se destinarán al financiamiento de proyectos para el desarrollo social, económico y ambiental de las entidades territoriales; al ahorro para su pasivo pensional; para inversiones físicas en educación, para inversiones en ciencia, tecnología e innovación; para la generación de ahorro público; para la fiscalización de la exploración y explotación de los yacimientos y conocimiento y cartografía geológica del subsuelo; y para aumentar la competitividad general de la economía buscando mejorar las condiciones sociales de la población.

Los departamentos, municipios y distritos en cuyo territorio se adelanten explotaciones de recursos naturales no renovables, así como los municipios y distritos con puertos marítimos y fluviales por donde se transporten dichos recursos o productos derivados de los mismos, tendrán derecho a participar en las regalías y compensaciones, así como a ejecutar directamente estos recursos. Para efectos de cumplir con los objetivos y fines del Sistema General de Regalías, créanse los Fondos de Ciencia, Tecnología e Innovación; de Desarrollo Regional; de Compensación Regional; y de Ahorro y Estabilización.

Lo puntualizado anteriormente sirve de premisa, entonces para llegar a las siguientes conclusiones: Que el Sistema general de regalías establecen como fines generales de los recursos el financiamiento de proyectos para el desarrollo social y ambiental de las entidades territoriales, entre otros componentes, buscando mejorar las condiciones sociales de las comunidades.

Que se crearon los fondos de ciencia, tecnología e innovación; de desarrollo regional; de compensación regional; y de ahorro y estabilización, quienes manejarán los recursos a quienes se les distribuirá un porcentaje equivalente del sistema general de regalías. Que los recursos del sistema general de regalías no harán parte del presupuesto general de la Nación, entre otros aspecto no propios de esta investigación.

El acto legislativo 5 de 2011, que modificó los artículos 360 y 361 de la Carta Constitucional fueron demandados por inconstitucional, argumentándose en el texto que hubo una "sustitución parcial" de la Constitución, lo que significa que el Congreso de la República excedió el poder de reforma Constitucional que le otorga la Constitución Política de 1991; la anterior demanda fue resuelta mediante sentencia C-010 de 2013 de la Corte Constitucional, la cual afirmó que: 
La dificultad que surge de esa definición, también analizada en la jurisprudencia Constitucional, consiste en circunscribir el concepto Estado para tales efectos. Para ello, la Corte ha concluido que (i) ese concepto tiene naturaleza compleja, pues incluye tanto a la Nación, comprendida como expresión del Estado central, al igual que las entidades territoriales; y (ii) de acuerdo con lo anterior, las entidades territoriales, entre ellas las beneficiarias de regalías directas en el régimen Constitucional anterior, carecen de derechos de propiedad sobre esas regalías, adscribiéndoseles solo derechos de participación en estas, al igual que en lo referente a las compensaciones. (Colombia, Sentencia, 2013)

Y por último en este recorrido de la Constitución Política Verde Colombiana, precisa en su artículo 366, lo siguiente:

El bienestar general y el mejoramiento de la calidad de vida de la población son finalidades sociales del Estado. Será objetivo fundamental de su actividad la solución de las necesidades insatisfechas de salud, de educación, de saneamiento ambiental y de agua potable.

Norma evidentemente que se identifica como garantía en la labor interpretativa de las finalidades sociales del Estado en forma sistémica con el artículo $2^{\circ}$ del Estatuto Constitucional fines esenciales del Estado, y centra en su objetivo fundamental en la solución de las necesidades insatisfechas, entre otras el saneamiento ambiental (artículo $49 \mathrm{CP}$ ).

Han confirmado el anterior postulado, lo que imparte una obligación de protección ambiental para la sociedad por parte del Estado, en busca del bienestar general y el mejoramiento de la calidad de vida de la población. Importante traer a colación la diferenciación que señala un autor mexicano, que afirma:

"Ambiente" no es sinónimo de "calidad de vida", aunque se trata de expresiones muy relacionadas. La expresión "calidad de vida" ha terminado introduciéndose en el campo del derecho, y especialmente en el derecho Constitucional. Es claro que las condiciones del ambiente físico influyen en la calidad de vida de las personas, pero es también evidente la influencia del ambiente social de las personas. La idea de calidad de vida de las personas excede entonces la de calidad del ambiente físico. Por otro lado, debe recordarse que el 
concepto de calidad de vida está asociado estrechamente con el "desarrollo humano".

(Brañes, 2000, p.26)

\subsubsection{Título XIII. De La Reforma De La Constitución. Art. 374 - 380}

En éste último título de la Constitución Política no se enuncia ningún articulado que esté ligado con la planificación en el manejo y aprovechamiento de los recursos naturales renovables, como el recurso hídrico, la flora, la fauna, el suelo, el aire (olores, material particulado, ruido), ni postulados ambientales; en este orden de ideas, sin análisis en materia ambiental al respecto.

De acuerdo con el recuento y análisis realizado bajo el enfoque de la planificación ambiental se culmina el presente capítulo con el recorrido de los 380 artículos, estructurado en 13 títulos Constitucionales.

\subsection{Conclusiones del capítulo.}

Importante afirmar, que las normas ambientales contenidas en el Estatuto Constitucional de 1991, son normas sin antecedentes en la historia Constitucional Colombiana, precisando que en la Constitución de 1886 no se enuncia un componente ambiental directo; y es la Carta política de 1991 que trae un piso ambiental sólido compuesto por treinta y cinco (35) artículos que hemos denominado "La Constitución Verde de Colombia", y que representa una dualidad en el sentido de que fue calificado por la Corte Constitucional como un derecho-deber, por cuanto exige de las autoridades y de los particulares obligaciones y acciones encaminadas a su control, protección y conservación.

Expuesto el marco teórico en torno al derecho ambiental Constitucional, se concluye que la planificación en forma adecuada y razonable en el manejo y aprovechamiento de los recursos naturales es una obligación que le corresponde al Estado Colombiano, y está enfocado primordialmente a garantizar el desarrollo sostenible, la conservación, protección y la restauración de los recursos naturales renovables (artículo $80 \mathrm{CP}$ ), en procura de buscar el bienestar general y el mejoramiento de la calidad de vida de sus asociados.

De igual forma por mandato Constitucional, el Estado a través de sus entidades gubernamentales deberá prevenir y controlar los factores de deterioró ambiental. 
Es sustancial resaltar y siguiendo los criterios Constitucionales expresados, que el Estado deberá imponer las sanciones y exigir la reparación de los daños causados, enfocado a salvaguardar el derecho que tienen todas las personas a gozar de un ambiente sano (artículo 79 $\mathrm{CP})$, reconocido por la Corte Constitucional como un derecho fundamental en conexidad con la vida humana.

En coherencia con lo precedente, el derecho fundamental a un ambiente sano en armonía con el derecho de la propiedad privada, podemos concluir que en Colombia existe una propiedad privada relativa y no absoluta, que toda propiedad privada cumple una función social y ecológica, y que el interés general ambiental prima sobre el interés particular (artículo $58 \mathrm{CP}$ ).

Es el soporte Constitucional de la función social y ambiental de la propiedad privada, y sistémicamente relacionado con la libertad de la actividad económica y la iniciativa privada, dentro de los límites del bien común y ecológico como un derecho con sus respectivas responsabilidades, intrínsecamente la ambiental (artículo $333 \mathrm{CP}$ ).

En lo que respecta, la empresa como base del desarrollo por mandato Constitucional tiene una función social que implica obligaciones y es al legislativo que le corresponde delimitar el alcance de la libertad económica, cuando así lo exijan el interés social y el ambiental.

El análisis precedente, conlleva a señalar que si debe existir una regulación o reglamentación legal como responsabilidad ambiental del Estado entorno a la planificación de los recursos naturales renovables, con fundamento en los anteriores soportes Constitucionales. 


\section{CAPÍTULO SEGUNDO}

\section{LA PLANIFICACIÓN AMBIENTAL FUNCIÓN DE LAS AUTORIDADES PÚBLICAS}

Partiendo de los postulados constitucionales ambientales expuestos en el capítulo precedente, quedaron evidenciadas: la obligación del Estado de realizar la planificación en el manejo y aprovechamiento de los recursos naturales renovables, la función ecológica de la propiedad privada y la función social y ambiental que deben cumplir las empresas; es en este sentido que nos obliga la trascendencia en el tema, en identificar las entidades que ejercen autoridad ambiental en Colombia y precisar sus funciones, seguido, analizar otras instituciones que sin ser autoridad ambiental tienen asignadas funciones constitucionales y legales de orden ambiental.

Lo preliminar, en busca de identificar a las autoridades públicas que deban realizar la función de planificación u ordenamiento ambiental de acuerdo a su jurisdicción; en este orden de ideas, con el fin de identificar la reglamentación legal respecto al postulado ambiental contemplado en el artículo 80 Constitucional.

Antes de partir, es importante mencionar el aspecto geográfico de Colombia, un país ubicado en América del sur, bordeado por dos océanos, con múltiple biodiversidad, en el que, al interior de su jurisdicción, se ubican más de cincuenta y cinco áreas protegidas del orden nacional (parques nacionales naturales) de enormes riquezas ambientales, ubicados en diferentes departamentos; y en su estructura de Estado, cuenta de forma atípica con varias entidades que ejercen funciones de autoridad ambiental y otras que realizan acciones ambientales de forma similar al interior de un mismo departamento o región y municipio.

Para atender los validos planteamientos enunciados, traemos a colación que es el Sistema Nacional Ambiental - SINA, el cual de acuerdo con la ley 99 de 1993 "Por la cual se crea el Ministerio del Medio Ambiente, se reordena el Sector Público encargado de la gestión y conservación del medio ambiente y los recursos naturales renovables, se organiza el Sistema Nacional Ambiental, SINA", en su artículo $4^{\circ}$ estableció que: 
El Sistema Nacional Ambiental - SINA, es el conjunto de orientaciones, normas, actividades, recursos, programas e instituciones que permiten la puesta en marcha de los principios generales ambientales. Estará integrado por los siguientes componentes:

1) Los principios y orientaciones generales contenidos en la Constitución Nacional, en esta Ley y en la normatividad ambiental que la desarrolle. 2) La normatividad específica actual que no se derogue por esta ley y la que se desarrolle en virtud de la Ley. 3) Las entidades del Estado responsables de la política y de la acción ambiental, señaladas en la Ley. 4) Las organizaciones comunitarias y no gubernamentales relacionadas con la problemática ambiental. 5) Las fuentes y recursos económicos para el manejo y la recuperación del medio ambiente. 6) Las entidades públicas, privadas o mixtas que realizan actividades de producción de información, investigación científica y desarrollo tecnológico en el campo ambiental. (Colombia, Congreso Nacional de la República, 1993)

Precisa el parágrafo de la norma en comento que "Para todos los efectos la jerarquía en el Sistema Nacional Ambiental - SINA, seguirá el siguiente orden descendente: Ministerio de Ambiente, Corporaciones Autónomas Regionales, Departamentos y Distritos o Municipios"; es en igual sentido que desarrollaremos el presente capítulo, llevando un orden lógico y coherente con la estructura del Sistema Nacional Ambiental, y finalizar con otras autoridades públicas que realizan funciones ambientales, así:

\subsection{Del Ministerio de Ambiente y Desarrollo Sostenible - MADS}

Anteriormente, llamado Ministerio del medio ambiente (MMA) de acuerdo con lo estipulado en la ley 99 de 1993, posteriormente denominado Ministerio de Ambiente, Vivienda y Desarrollo Territorial (MAVDT) de conformidad con el decreto ley 216 de 2003; actualmente escindido y reorganizado de conformidad con el artículo 11 y 12 la ley 1444 de 2011 y hoy denominado Ministerio de Ambiente y Desarrollo Sostenible (MADS) y con el decreto 3570 de 2011 se modificaron sus objetivos, estructura y la integración del sector administrativo de ambiente y desarrollo sostenible; en su artículo $1^{\circ}$ precisa sus objetivos, así:

A. El Ministerio de Ambiente y Desarrollo Sostenible es el rector de la gestión del ambiente y de los recursos naturales renovables. Resalta importancia precisar, que al tener el objetivo de rector de la gestión del ambiente y de los recursos naturales renovables, conlleva 
implícito el legado Constitucional de planificar el manejo y aprovechamiento de los recursos naturales renovables.

B. Es el encargado de orientar y regular el ordenamiento ambiental del territorio; en armonía con lo dispuesto en el artículo $2^{\circ} \mathrm{CP}$, respecto a los fines esenciales del Estado de mantener la integridad territorial y el artículo3 numeral 2 de la ley 388 de 1997, que precisa:

El ordenamiento del territorio constituye en su conjunto una función pública, para: Atender los procesos de cambio en el uso del suelo y adecuarlo en aras del interés común, procurando su utilización racional en armonía con la función social de la propiedad a la cual le es inherente una función ecológica, buscando el desarrollo sostenible. (Colombia, Congreso Nacional de la República, 1997)

C. El Ministerio de Ambiente y Desarrollo Sostenible es el encargado de definir las políticas y regulaciones a las que se sujetarán la recuperación, conservación, protección, ordenamiento, manejo, uso y aprovechamiento sostenible de los recursos naturales renovables y del ambiente de la Nación. Paso importante y escalón posterior después de realizar la planificación ambiental de que trata el artículo 80 constitucional.

D. Formular junto con el Presidente de la República la política nacional ambiental y de recursos naturales renovables, de manera que se garantice el derecho de todas las personas a gozar de un medio ambiente sano y se proteja el patrimonio natural y la soberanía de la Nación.

E. Dirigir el Sistema Nacional Ambiental (SINA), organizado de conformidad con la ley 99 de 1993, para asegurar la adopción y ejecución de las políticas, planes, programas y proyectos respectivos, en orden a garantizar el cumplimiento de los deberes y derechos del Estado y de los particulares en relación con el ambiente y el patrimonio natural de la Nación.

Por tal razón continuaremos con las funciones del Ministerio de Ambiente y Desarrollo Sostenible - MADS, que además de las funciones asignadas en la Constitución Nacional, en el artículo 59 de la ley 489 de 1998 y en las demás leyes, fueron asignadas en el artículo $2^{\circ}$ del decreto 3570 de 2011, las siguientes funciones:

1. Diseñar y formular la política nacional en relación con el ambiente y los recursos naturales renovables, y establecer las reglas y criterios de ordenamiento ambiental de uso del territorio y de los mares adyacentes, para asegurar su conservación y el aprovechamiento sostenible de los recursos naturales renovables y del ambiente. 
2. Diseñar y regular las políticas públicas y las condiciones generales para el saneamiento del ambiente, y el uso, manejo, aprovechamiento, conservación, restauración y recuperación de los recursos naturales, a fin de impedir, reprimir, eliminar o mitigar el impacto de actividades contaminantes, deteriorantes o destructivas del entorno o del patrimonio natural, en todos los sectores económicos y productivos.

3. Apoyar a los demás Ministerios y entidades Estatales, en la formulación de las políticas públicas, de competencia de los mismos, que tengan implicaciones de carácter ambiental y desarrollo sostenible, y establecer los criterios ambientales que deben ser incorporados en esta formulación de las políticas sectoriales.

4. Participar con el Ministerio de Relaciones Exteriores en la formulación de la política internacional en materia ambiental y definir con este los instrumentos y procedimientos de cooperación, y representar al Gobierno Nacional en la ejecución de tratados y convenios internacionales sobre ambiente, recursos naturales renovables y desarrollo sostenible.

5. Orientar, en coordinación con el Sistema Nacional de Prevención y Atención de Desastres, las acciones tendientes a prevenir el riesgo ecológico. Y, 6. Preparar, con la asesoría del Departamento Nacional de Planeación, los planes, programas y proyectos que en materia ambiental, o en relación con los recursos naturales renovables y el ordenamiento ambiental del territorio, deban incorporarse a los proyectos del Plan Nacional de Desarrollo y del Plan Nacional de Inversiones que el Gobierno someta a consideración del Congreso de la República.

7. Evaluar los alcances y efectos económicos de los factores ambientales, su incorporación al valor de mercado de bienes y servicios y su impacto sobre el desarrollo de la economía nacional y su sector externo; su costo en los proyectos de mediana y grande infraestructura, así como el costo económico del deterioro y de la conservación del medio ambiente y de los recursos naturales renovables.

8. Realizar investigaciones, análisis y estudios económicos y fiscales en relación con los recursos presupuestales y financieros del sector de gestión ambiental, tales como, impuestos, tasas, contribuciones, derechos, multas e incentivos con él relacionados; y fijar el monto tarifario mínimo de las tasas por el uso y el aprovechamiento de los recursos naturales renovables, de conformidad con la ley. 
9. Dirigir y coordinar el proceso de planificación y la ejecución armónica de las actividades en materia ambiental de las entidades integrantes del Sistema Nacional Ambiental (SINA), dirimir las discrepancias ocasionadas por el ejercicio de sus funciones y establecer criterios o adoptar decisiones cuando surjan conflictos entre ellas en relación con la aplicación de las normas o con las políticas relacionadas con el uso, manejo y aprovechamiento de los recursos naturales renovables o del ambiente.

10. Ejercer la inspección y vigilancia sobre las Corporaciones Autónomas Regionales, y ejercer discrecional y selectivamente, cuando las circunstancias lo ameriten, sobre los asuntos asignados a estas corporaciones la evaluación y control preventivo, actual o posterior, de los efectos del deterioro ambiental que puedan presentarse por la ejecución de actividades o proyectos de desarrollo, así como por la exploración, explotación, transporte, beneficio y utilización de los recursos naturales renovables y no renovables, y ordenar al organismo nacional competente para la expedición de licencias ambientales a cargo del Ministerio de Ambiente y Desarrollo Sostenible, la suspensión de los trabajos o actividades cuando a ello hubiese lugar.

11. Coordinar, promover y orientar las acciones de investigación sobre el ambiente y los recursos naturales renovables y sobre modelos alternativos de desarrollo sostenible. Y, 12. Establecer el Sistema de Información Ambiental, organizar el inventario de la biodiversidad y de los recursos genéticos nacionales; y administrar el Fondo Nacional Ambiental (Fonam) y sus subcuentas.

13. Diseñar y formular la política, planes, programas y proyectos, y establecer los criterios, directrices, orientaciones y lineamientos en materia de áreas protegidas, y formular la política en materia del Sistema de Parques Nacionales Naturales.

14. Reservar y alinderar las áreas que integran el Sistema de Parques Nacionales Naturales; declarar, reservar, alinderar, realinderar, sustraer, integrar o recategorizar las áreas de reserva forestal nacionales, reglamentar su uso y funcionamiento; y declarar y sustraer Distritos Nacionales de Manejo Integrado. Las corporaciones autónomas regionales en desarrollo de su competencia de administrar las reservas forestales nacionales, de conformidad con lo dispuesto en el artículo 31 de la ley 99 de 1993, realizarán los estudios técnicos, ambientales y socioeconómicos para los fines previstos en el presente numeral, con base en los lineamientos establecidos por este Ministerio. 
15. Elaborar los términos de referencia para la realización de los estudios con base en los cuales las autoridades ambientales declararán, reservarán, alinderarán, realinderarán, sustraerán, integrarán o recategorizarán, las reservas forestales regionales y para la delimitación de los ecosistemas de páramo y humedales sin requerir la adopción de los mismos por parte del Ministerio. Y, 16. Expedir los actos administrativos para la delimitación de los páramos.

17. Adquirir, en los casos expresamente definidos en la Ley 99 de 1993, los bienes de propiedad privada y los patrimoniales de las entidades de derecho público; adelantar ante la autoridad competente la expropiación de bienes por razones de utilidad pública o interés social definidas por la ley, e imponer las servidumbres a que hubiese lugar.

18. Constituir con otras personas jurídicas de derecho público o privado, asociaciones, fundaciones o entidades para la conservación, manejo, administración y gestión de la biodiversidad, promoción y comercialización de bienes y servicios ambientales, velando por la protección del patrimonio natural del país. (Colombia, Departamento Administrativo de la Función Pública, 2011)

No puede guardarse silencio en una investigación de legalidad ambiental, frente a postulados que rayan con la línea jurisprudencial de la Corte Constitucional, si bien es cierto, que el tema no es del resorte de este escrito, menos es cierto que otorgar silencio nos convierte en cómplice de los yerros jurídicos; y el caso de marras es respecto a la función asignada al MADS enunciada en el numeral 14 del artículo $2^{\circ}$ del decreto 3570 de 2011, así "Reservar y alinderar las áreas que integran el Sistema de Parques Nacionales Naturales; (...); y declarar y sustraer Distritos Nacionales de Manejo Integrado"; la expresión "y sustraer" debería ser declarada inexequible de acuerdo a los argumentos de la sentencia C-598 de 2010, por la cual declaro “inexequible la expresión "o sustraer” contenida en el numeral 16 del artículo 31 de la ley 99 de 1993", de las funciones de las Corporaciones autónomas regionales - CAR. (Colombia, Sentencia, 2010)

Entrando en materia de la investigación, previa lectura de los objetivos y las funciones asignadas al Ministerio de Ambiente y Desarrollo Sostenible, se determina que la función consagrada en el artículo 80 de la Constitución Política asignada al Estado en planificar el manejo y aprovechamiento de los recursos naturales, no figura puntualmente; se observan 
aproximaciones en las funciones y los objetivos, pero no se vislumbra una función específica frente a éste tema y menos aún, se observa que se precise al MADS de realizar un diagnóstico e inventario de los recursos naturales renovables de la Nación. Línea que se abordará con mayor profundidad en el capítulo tercero de la planificación ambiental.

De otra parte, teniendo como fundamento una interpretación armónica y sistemática, se observa que el Ministerio de Ambiente y Desarrollo Sostenible no tiene dientes sancionatorios, la facultad de legalizar e imponer medidas preventivas, incoar procesos administrativos sancionatorios, realizar el seguimiento y control, realizar trámites de permisos o autorizaciones ambientales, imponer multas y sanciones ha desaparecido dentro de su órbita funcional directa; por consiguiente es una entidad nacional que no puede ser considerada autoridad ambiental; en su defecto, es el ente rector de la gestión del ambiente y de los recursos naturales renovables, que marca la política pública en materia ambiental para el país.

\subsection{De la Autoridad Nacional de Licencias Ambientales - ANLA}

Se debe destacar de manera especial que esta entidad ambiental es relativamente nueva, lleva de existencia tres años aproximados, y su nacimiento a la vía jurídica se da a través del decreto N 3573 de 2011 "Por el cual se crea la Autoridad Nacional de Licencias Ambientales ANLA- y se dictan otras disposiciones" como una Unidad Administrativa Especial -UAE- del orden nacional, con autonomía administrativa y financiera, sin personería jurídica, siendo parte del Sector Administrativo de Ambiente y Desarrollo Sostenible.

La Autoridad Nacional de Licencias Ambientales -ANLA- tiene como objeto que los proyectos, obras o actividades de grandes magnitudes o nacionales sujetos de licenciamiento, permiso o trámite ambiental cumplan con el marco legal ambiental, con la finalidad de contribuir al desarrollo sostenible de Colombia.

En su artículo $3^{\circ}$ del decreto 3573 de 2011, se fijaron las funciones a la Autoridad Nacional de Licencias Ambientales -ANLA-, así:

1. Otorgar o negar las licencias, permisos y trámites ambientales de competencia del Ministerio de Ambiente y Desarrollo Sostenible, de conformidad con la ley. 2. Realizar el seguimiento de las licencias, permisos y trámites ambientales. 3. Administrar el Sistema de 
Licencias, Permisos y Trámites Ambientales -SILA- y Ventanilla Integral de Trámites Ambientales en Línea-Vital-.

4. Velar porque se surtan los mecanismos de participación ciudadana de que trata la ley relativos a licencias, permisos y trámites ambientales. 5. Implementar estrategias dirigidas al cuidado, custodia y correcto manejo de la información de los expedientes de licencias, permisos y trámites ambientales. 6. Apoyar la elaboración de la reglamentación en materia ambiental.

7. Adelantar y culminar el procedimiento de investigación, preventivo y sancionatorio en materia ambiental, de acuerdo con lo dispuesto en la Ley 1333 de 2009 o la norma que la modifique o sustituya. 8. Adelantar los cobros coactivos de las sumas que le sean adeudadas a la Autoridad Nacional de Licencias Ambientales -ANLA- por todos los conceptos que procedan.

9. Ordenar la suspensión de los trabajos o actividades, en los casos en los que el Ministerio de Ambiente y Desarrollo Sostenible haga uso del ejercicio discrecional y selectivo sobre los asuntos asignados a las Corporaciones Autónomas Regionales.

10. Aprobar los actos administrativos de licencias ambientales para explotaciones mineras y de construcción de infraestructura vial y los permisos y concesiones de aprovechamiento forestal de que tratan los artículos 34, 35 y 39 de la Ley 99 de 1993.

11. Dirimir los conflictos de competencia cuando el proyecto, obra o actividad sujeto a licencia o permiso ambiental se desarrolle en jurisdicción de dos o más autoridades ambientales. 12. Desarrollar la política de gestión de información requerida para el cumplimiento de su objeto. $Y, 13$. Asumir la representación judicial y extrajudicial de la Nación en los asuntos de su competencia, y Las demás funciones que le asigne la ley. (Colombia, Departamento Administrativo de la Función Pública, 2011)

Continuando como vector de la presente investigación y realizando el estudio de las funciones adscrita a la Autoridad Nacional de Licencias Ambientales -ANLA-, nos es pertinente afirmar que la función constitucional asignada al Estado de planificar el manejo y aprovechamiento de los recursos naturales, no es del resorte del ANLA; de igual forma, frente al contexto de la responsabilidad social ambiental no se vislumbra una función específica frente a éste tema. En este orden de ideas, la ANLA tiene su esencia como autoridad ambiental nacional 
la de iniciar, tramitar y expedir licencias ambientales y sus permisos conexos y aplicar el régimen sancionatorio administrativo a las personas naturales o jurídicas que incumplan las normas ambientales y/o quienes realicen afectaciones a los recursos naturales renovables.

A diferencia del Ministerio de Ambiente y Desarrollo Sostenible, le corresponde a la Autoridad Nacional de Licencias Ambientales la facultad de imponer medidas preventivas, iniciar procesos administrativos sancionatorios, imponer multas y sanciones de conformidad con la ley 1333 de 2009 y presentar las denuncias penales por los delitos ambientales.

Por último, hacer una apreciación general frente al ANLA, ya que por tener su domicilio en Bogotá, se evidencia que falta mayor control y seguimiento de estas obra u proyectos licenciados ambientalmente, ya que esta función es netamente de la autoridad ambiental que expide el permiso ambiental y es quien cobra el estudio y evaluación y seguimiento, no correspondiéndole a la autoridad ambiental regional o CAR; bajo este contexto, la falta o escaso seguimiento periódico y constate por el ANLA permite que los titulares de los permisos realicen las afectaciones ambientales y deterioro de los recursos naturales renovables. Sin obviar, que en diferentes oportunidades, cuando el personal de la Autoridad Nacional de Licencias Ambientales se dispone a realizar una visita de seguimiento y control al proyecto u obra, da aviso con anticipación y claro está, que cuando se hace la visita, todo se encuentra en orden y adecuado de conformidad.

\subsection{De la Unidad Administrativa Especial de Parques Nacionales Naturales}

Los Parques Nacionales Naturales son áreas protegidas del orden nacional, son terrenos delimitados donde se encuentran las grandes riquezas ambientales de nuestro país, son los sitios que tiene mayor grado de conservación y brilla en abundancia la biodiversidad, son paraísos naturales, son los grandes jardines de Colombia, describirlos en palabras no existe tal definición por su belleza indescriptible, es verlos y olerlos, tocarlos para poder sentir las maravillas naturales existentes en Colombia.

Y en este contexto mágico natural, ingresamos al campo histórico jurídico, y, fue la ley $2^{\mathrm{a}}$ de 1959 quien puso su primer punto sobre el tema de los parques nacionales naturales, en especial su artículo 13 que precisa: 
Con el objeto de conservar la flora y la fauna nacionales, declárese "Parques Nacionales Naturales" aquellas zonas que el Gobierno Nacional, por intermedio del Ministerio de Agricultura, previo concepto favorable de la Academia Colombiana de Ciencias Exactas, físicas y Naturales, delimite y reserve de manera especial, por medio de Decretos, en las distintas zonas del país y en sus distintos pisos térmicos, y en las cuales, quedará prohibida la adjudicación de baldíos, las ventas de tierras, la caza la pesca, y toda actividad industrial, ganadera o agrícola, distinta a la del turismo o a aquellas que el Gobierno Nacional considera convenientes para la conservación o embellecimiento de la zona.

Posteriormente, se formalizó la definición de parques nacionales naturales, los tipos de áreas, las actividades permitidas y prohibidas al interior de éstas áreas protegidas, específicamente en los artículos 327 al 336 del decreto ley 2811 de 1974 (Código Nacional de los Recursos Naturales); entendiéndose como:

Se denomina sistema de parques nacionales el conjunto de áreas con valores excepcionales para el patrimonio nacional que, en beneficio de los habitantes de la Nación y debido a sus características naturales, culturales o históricas, se reserva y declara comprendida en cualquiera de las categorías que adelante se enumeran.

Tres años después se profiere la reglamentación para el Sistema de Parques Nacionales Naturales, mediante el decreto 622 de 1977, y en la actualidad con el decreto 3572 de 2011 se crea como una Unidad Administrativa Especial denominada Parques Nacionales Naturales de Colombia, se determinan sus objetivos, estructura y se asignan funciones, así:

1. Administrar y manejar el Sistema de Parques Nacionales Naturales, así como reglamentar el uso y el funcionamiento de las áreas que lo conforman, según lo dispuesto en el Decreto-Ley 2811 de 1974, Ley 99 de 1993 y sus decretos reglamentarios. 2. Proponer e implementar las políticas y normas relacionadas con el Sistema de Parques Nacionales Naturales. 3. Formular los instrumentos de planificación, programas y proyectos relacionados con el Sistema de Parques Nacionales Naturales.

4. Adelantar los estudios para la reserva, alinderación, delimitación, declaración y ampliación de las áreas del Sistema de Parques Nacionales Naturales. 5. Proponer al Ministerio de Ambiente y Desarrollo Sostenible las políticas, planes, programas, proyectos y normas en materia del Sistema Nacional de Áreas Protegidas. 6. Coordinar la conformación, funcionamiento y consolidación del Sistema Nacional de Áreas Protegidas, 
de acuerdo con las políticas, planes, programas, proyectos y la normativa que rige dicho Sistema.

7. Otorgar permisos, concesiones y demás autorizaciones ambientales para el uso y aprovechamiento de los recursos naturales renovables en las áreas del Sistema de Parques Nacionales Naturales y emitir concepto en el marco del proceso de licenciamiento ambiental de proyectos, obras o actividades que afecten o puedan afectar las áreas del Sistema de Parques Nacionales Naturales. 8. Adquirir por negociación directa o expropiación los bienes de propiedad privada, los patrimoniales de las entidades de derecho público y demás derechos constituidos en predios ubicados al interior del Sistema de Parques Nacionales Naturales e imponer las servidumbres a que haya lugar sobre tales predios.

9. Liquidar, cobrar y recaudar conforme a la ley, los derechos, tasas, multas, contribuciones y tarifas por el uso y aprovechamiento de los recursos naturales renovables de las áreas del Sistema de Parques Nacionales Naturales y de los demás bienes y servicios ambientales suministrados por dichas áreas. 10. Recaudar, conforme a la ley, los recursos por concepto de los servicios de evaluación y seguimiento de los permisos, las concesiones, las autorizaciones y los demás instrumentos de control y manejo ambiental establecidos por la ley y los reglamentos.

11. Proponer conjuntamente con las dependencias del Ministerio de Ambiente y Desarrollo Sostenible, las políticas, regulaciones y estrategias en materia de zonas amortiguadoras de las áreas del Sistema de Parques Nacionales Naturales. 12. Administrar el registro único nacional de áreas protegidas del SINAP.... Y, 14. Proponer e implementar estrategias de sostenibilidad financiera para la generación de recursos, que apoyen la gestión del organismo. (Colombia, Departamento Administrativo de la Función Pública, 2011)

Previa lectura de las funciones asignadas al Unidad Administrativa Especial de Parques Nacionales Naturales, nos permito precisar que la función consagrada en el artículo 80 de la Constitución Política asignada al Estado en planificar el manejo y aprovechamiento de los recursos naturales, no le fue asignada frente al marco de la responsabilidad social ambiental Estatal.

A diferencia del Ministerio de Ambiente y Desarrollo Sostenible, la Unidad Administrativa Especial de Parques Nacionales Naturales tiene dentro de sus competencias en su jurisdicción territorial la de imponer medidas preventivas, iniciar procesos administrativos 
sancionatorios, colocar multas y sanciones ambientales. En similitud con el Ministerio de Ambiente y Desarrollo Sostenible y el ANLA, su órbita funcional es en todo el territorio nacional; para el caso concreto esta entidad ejerce sus funciones al interior de sus 58 áreas naturales; clasificadas, así: Parques Nacionales Naturales, Santuarios de Fauna y Flora, Vía Parque, Reservas Natural y Área Natural Única, que corresponde aproximadamente el 12\% del territorio, en más de 14`254.000 hectáreas de la superficie nacional (marinas y terrestres).

\subsection{De las Corporaciones Autónomas Regionales - CAR}

Con fundamento Constitucional de acuerdo a lo estipulado en el artículo 150 numeral 7 de la Constitución Política, se facultó al legislador de reglamentar la creación y funcionamiento de las Corporaciones Autónomas Regionales dentro de un régimen de autonomía; posteriormente mediante la ley 99 de 1993, en su artículo 23, se afirma que:

Las Corporaciones Autónomas Regionales son entes corporativos de carácter público, creados por la ley, integrados por las entidades territoriales que por sus características constituyen geográficamente un mismo ecosistema o conforman una unidad geopolítica, biogeográfica o hidrogeográfica, dotados de autonomía administrativa y financiera, patrimonio propio y personería jurídica, encargados por la ley de administrar, dentro del área de su jurisdicción, el medio ambiente y los recursos naturales renovables y propender por su desarrollo sostenible, de conformidad con las disposiciones legales y las políticas del Ministerio del Medio Ambiente; hoy Ministerio de Ambiente y Desarrollo Sostenible.

En la norma en comento puntualmente en el artículo 31 de la ley 99 de 1993, le asignan funciones como autoridad ambiental regional, entre ellas:

1) Ejecutar las políticas, planes y programas nacionales en materia ambiental definidos por la ley aprobatoria del Plan Nacional de Desarrollo y del Plan Nacional de Inversiones o por el Ministerio del Medio Ambiente, así como los del orden regional que le hayan sido confiados conforme a la ley, dentro del ámbito de su jurisdicción; 2) Ejercer la función de máxima autoridad ambiental en el área de su jurisdicción; 3) promover y desarrollar la participación comunitaria en programas de protección ambiental, de desarrollo sostenible y de manejo adecuado de los recursos naturales renovables; 8) ejecutar programas de educación ambiental no formal; 9) otorgar concesiones para el uso de aguas superficiales y subterráneas, permisos, autorizaciones y licencias ambientales para el uso, 
aprovechamiento o movilización de los recursos naturales renovables o para el desarrollo de actividades que afecten o puedan afectar el medio ambiente; establecer vedas para la caza y pesca deportiva.

Fundado en el principio de rigor subsidiario le corresponde a las CAR fijar en el área de su jurisdicción, los límites permisibles de emisión, descarga, transporte o depósito de sustancias, productos, compuestos o cualquier otra materia que puedan afectar el medio ambiente o los recursos naturales renovables y prohibir restringir o regular la fabricación, distribución, uso disposición o vertimiento de sustancias causantes de degradación ambiental; así mismo, ejercer las funciones de evaluación, control y seguimiento ambiental de las actividades de exploración, explotación, beneficio, transporte, uso y depósito de los recursos naturales no renovables, así como de otras actividades, proyectos o factores que generen o puedan generar deterioro.

Ejercer las funciones de evaluación, control y seguimiento ambiental de los usos del agua, el suelo, el aire y los demás recursos naturales renovables, lo cual comprenderá el vertimiento, emisión o incorporación de sustancias o residuos líquidos, sólidos y gaseosos, a las aguas en cualquiera de sus formas, al aire o a los suelos, así como los vertimientos o emisiones que puedan causar daño o poner en peligro el normal desarrollo sostenible de los recursos naturales renovables; imponer y ejecutar las medidas de policía y las sanciones previstas en la ley, en caso de violación a las normas de protección ambiental y de manejo de recursos naturales renovables y exigir la reparación de daños causados.

En igual sentido, las autoridades ambientales pueden otorgar reconocimientos o estímulos a las personas naturales o jurídicas, que con sus acciones o proyectos que contribuyan al mejoramiento ambiental bajo el enfoque de la responsabilidad social ambiental.

La crisis en las Corporaciones Autónomas Regionales, se funda actualmente en la conformación de sus órganos de dirección y administración, hoy contenidos en el artículo 24, 25, 26 y 27 de la ley 99 de 1993, así “Las Corporaciones Autónomas Regionales tendrán tres órganos principales de dirección y administración a saber: a. La Asamblea Corporativa; b. El Consejo Directivo; y c. El Director General".

De la Asamblea Corporativa. Es el principal órgano de dirección de la Corporación y estará integrada por todos los representantes legales de las entidades territoriales de su jurisdicción. Son funciones de la Asamblea Corporativa: a. Elegir el Consejo Directivo. 
Del Consejo Directivo. Es el órgano de administración de la Corporación y estará conformado por: a. El gobernador o los gobernadores de los departamentos sobre cuyo territorio ejerza jurisdicción la Corporación Autónoma Regional. Corresponderá al gobernador o a su delegado presidir el Consejo Directivo; $b$. Un representante del Presidente de la República; c. Un representante del Ministro del Medio Ambiente; d. Hasta cuatro (4) alcaldes de los municipios comprendidos dentro del territorio de la jurisdicción de la Corporación, elegidos por la Asamblea Corporativa; e. Dos (2) representantes del sector privado; $f$. Un (1) representante de las comunidades indígenas o etnias tradicionalmente asentadas en el territorio de jurisdicción de la Corporación, elegido por ellas mismas; g. Dos (2) representantes de las entidades sin ánimo de lucro, que tengan su domicilio en el área de jurisdicción de la Corporación y cuyo objeto principal sean la protección del medio ambiente y los recursos naturales renovables, elegido por ellas mismas.

De las Funciones del Consejo Directivo: a. Proponer a la Asamblea Corporativa la adopción de los Estatutos y de sus reformas; j. Nombrar o remover de conformidad al Director General de la Corporación”.

De la simple lectura precedida se extrae que la composición de los órganos de administración y dirección de las Corporaciones autónomas regionales, tienen un tinte político, es decir, está compuesta por los alcaldes del área de jurisdicción, por el gobernador del departamento, el representante del Presidente de la República y el representante del Ministerio de Ambiente y Desarrollo Sostenible son ellos quienes eligen al director general de las CAR. En casos particulares, los alcaldes son infractores ambientales y son sancionados por los directores generales de las autoridades ambientales regionales; quienes después debe ir y solicitar su voto para ser reelegidos; se convierte de aliados ambientales a opositores institucionales.

De otra parte en el consejo directivo de las CAR se encuentran dos representantes de las ONG ambientalistas y dos representantes del sector privado, siendo una falencia burocrática; por designarse entre ellos mismos, personas que en ocasiones no tienen conocimiento técnico ambiental, simplemente están sentados en la administración por intereses particulares, y descuidan la verdadera esencia de estar en los consejos directivos para direccionar a la autoridad ambiental regional, que debe tener un enfoque de coadyuvar a elevar la calidad de vida de las personas, el bienestar social en armonía con la naturaleza y el desarrollo sostenible moderno. 
Se colige que, de las más de treinta funciones asignadas a las Corporaciones autónomas regionales, frente a nuestra investigación encontramos que las CAR no tiene la obligación de que trata el artículo 80 Constitucional, respecto a la obligación del Estado de planificar el manejo y aprovechamiento de los recursos naturales renovables.

Es también de anotar que las CAR tiene dentro de sus funciones la de participar con los demás organismos y entes competentes en el ámbito de su jurisdicción, en los procesos de planificación y ordenamiento territorial a fin de que el factor ambiental sea tenido en cuenta en las decisiones que se adopten; $y$, seguido corresponde apoyar a los concejos municipales, a las asambleas departamentales y a los consejos de las entidades territoriales indígenas en las funciones de planificación que les otorga la Constitución Nacional.

\subsection{De los Departamentos y Asamblea Departamental}

La Constitución Política en el artículo 298 establece que los “departamentos tienen autonomía para la administración de asuntos seccionales y la planificación y promoción del desarrollo económico y social dentro de su territorio en los términos establecidos en la Constitución" lo cual involucra también el ambiente.

El artículo 299 y 300 de la Constitución Nacional, determinan que cada departamento tendrá una corporación político administrativa que se denominará Asamblea Departamental y esta institución tendrá su manifestación mediante ordenanzas, entre ellos, los siguientes temas:

Expedir las disposiciones relacionadas con la planeación, el desarrollo económico y social, el apoyo financiero y crediticio a los municipios, el turismo, el transporte, el ambiente, las obras públicas, las vías de comunicación y el desarrollo de sus zonas de frontera y Dictar normas de policía en todo aquello que no sea materia de disposición legal.

La ley 99 de 1993, en el artículo 64, numeral 1, determina que corresponde a los departamentos en materia ambiental, sin ser autoridad ambiental, las siguientes atribuciones especiales:

Promover y ejecutar programas y políticas nacionales, regionales y sectoriales en relación con el medio ambiente y los recursos naturales renovables. Expedir, con sujeción a las normas superiores, las disposiciones departamentales especiales relacionadas con el medio 
ambiente. Dar apoyo presupuestal, técnico, financiero y administrativo a las corporaciones autónomas regionales, a los municipios y a las demás entidades territoriales que se creen en el ámbito departamental, en la ejecución de programas y proyectos y en las tareas necesarias para la conservación del medio ambiente y los recursos naturales renovables.

Ejercer, en coordinación con las demás entidades del Sistema Nacional Ambiental, SINA, y con sujeción a la distribución legal de competencias, funciones de control y vigilancia del medio ambiente y los recursos naturales renovables, con el fin de velar por el cumplimiento de los deberes del Estado y de los particulares en materia ambiental y de proteger el derecho a un ambiente sano. Coordinar y dirigir, con la asesoría de las corporaciones autónomas regionales, las actividades de control y vigilancia ambientales intermunicipales, que se realicen en el territorio del departamento con el apoyo de la fuerza pública, en relación con la movilización, procesamiento, uso, aprovechamiento y comercialización de los recursos naturales renovables.

Respecto al tema y en armonía con la responsabilidad ambiental del Estado en realizar la planificación de los recursos naturales renovables, la ley 99 de 1993 en su artículo 111, modificado por el artículo 210 de la ley 1450 de 2011 (vigencia extendida por la ley 1753 de 2015), enuncia que "Los departamentos y municipios dedicarán un porcentaje no inferior al $1 \%$ de sus ingresos corrientes para la adquisición y mantenimiento de áreas de interés para acueductos municipales o para financiar esquemas de pago por servicios ambientales" y reglamentado por el decreto 953 de mayo 17 de 2013. Aunado a lo precedente y en armonía con el tema se expidió la ley 373 de 1997, sobre protección del recurso hídrico.

\subsection{De los Distritos Especiales}

Importante precisar que la Constitución Política en su artículo 328, modificado por el artículo $2^{\circ}$ del acto legislativo 2 de 2007, señaló que “El Distrito Turístico y Cultural de Cartagena de Indias, el Distrito Turístico, Cultural e histórico de Santa Marta y Barranquilla conservarán su régimen y carácter, y se organiza a Buenaventura y Tumaco como Distrito Especial, Industrial, Portuario, Biodiverso y Ecoturismo”.

Resáltese el contenido del artículo 13 de la ley 768 de 2002, el cual precisó las competencias ambientales, así "Los Distritos de Cartagena, Santa Marta y Barranquilla ejercerán, 
dentro del perímetro urbano, las mismas funciones atribuidas a las Corporaciones Autónomas Regionales en lo que fuere aplicable al medio ambiente urbano".

Y es la ley 1617 de 2013, que modificó el tema y definió a los distritos como "entidades territoriales sujetos a un régimen especial, en virtud del cual sus órganos y autoridades gozan de facultades especiales" (art. $2^{\circ}$ ) y anteriormente el Plan Nacional de Desarrollo proferido mediante la ley 1450 de 2011, en su artículo 214 (vigencia extendida por la ley 1753 de 2015), había precisado que:

Competencias de los grandes centros urbanos y los establecimientos públicos ambientales. Los Grandes Centros Urbanos previstos en el artículo 66 de la Ley 99 de 1993 y los establecimientos públicos que desempeñan funciones ambientales en los Distritos de Barranquilla, Santa Marta y Cartagena, ejercerán dentro del perímetro urbano las mismas funciones atribuidas a las Corporaciones Autónomas Regionales y de Desarrollo Sostenible en lo que respecta a la protección y conservación del medio ambiente, con excepción de la elaboración de los planes de ordenación y manejo de cuencas hidrográficas. En relación con la gestión integral del recurso hídrico, los grandes centros urbanos y los establecimientos públicos ambientales a que hace referencia el presente artículo, ejercerán sus competencias sobre los cuerpos de agua que sean afluentes de los ríos principales de las subzonas hidrográficas que atraviesan el perímetro urbano y/o desemboquen en el medio marino, así como en los humedales y acuíferos ubicados en su jurisdicción.

La ley 1617 de 2013 "Por la cual se expide el Régimen para los Distritos Especiales”, en su artículo 124, otorga facultades para que los Distritos especiales de Barranquilla, Cartagena, Santa Marta y Buenaventura creen sus propios establecimientos públicos y serán los que ejercerán en su jurisdicción las mismas funciones de autoridad ambiental que a las asignadas a las Corporaciones autónomas ambientales; al respecto la norma aludida precisa:

La competencia ambiental deberá .ceñirse a lo consagrado en los artículos 79 y 80 de la Constitución. El concejo distrital, a iniciativa del alcalde, de acuerdo con lo establecido en el artículo 313 de la Constitución Política creará un Establecimiento Público, que desempeñará las funciones de autoridad ambiental en la jurisdicción del distrito. Parágrafo $4^{\circ}$. Las funciones de la autoridad ambiental que se crea en el marco de esta ley, son las establecidas en el artículo 66 de la Ley 99 de 1993. (Colombia, Congreso Nacional de la República, 2013) 


\subsection{De los Grandes Centros Urbanos y Áreas Metropolitanas}

Los Departamento Administrativo del Medio Ambiente - DAMA o Grandes Centros Urbanos - GCU, son creados mediante acuerdos, para cumplir con las funciones de autoridad ambiental exclusivamente en el perímetro urbano, previo cumplimiento de los requisitos contemplados en la ley 99 de 1993 en su artículo 66 modificado por la ley 1450 de 2011, artículo 214 -Plan Nacional de Desarrollo- (vigencia extendida por la ley 1753 de 2015), así:

Los municipios, distritos o áreas metropolitanas cuya población urbana fuere igual o superior a un millón de habitantes (1.000.000) ejercerán dentro del perímetro urbano las mismas funciones atribuidas a las Corporaciones Autónomas Regionales, en lo que fuere aplicable al medio ambiente urbano. Además de las licencias ambientales, concesiones, permisos y autorizaciones que les corresponda otorgar para el ejercicio de actividades o la ejecución de obras dentro del territorio de su jurisdicción, las autoridades municipales, distritales o metropolitanas tendrán la responsabilidad de efectuar el control de vertimientos y emisiones contaminantes, disposición de desechos sólidos y de residuos tóxicos y peligrosos, dictar las medidas de corrección o mitigación de daños ambientales y adelantar proyectos de saneamiento y descontaminación.

Los municipios, distritos o áreas metropolitanas de que trata el presente artículo asumirán ante las Corporaciones Autónomas Regionales la obligación de transferir el $50 \%$ del recaudo de las tasas retributivas o compensatorias causadas dentro del perímetro urbano y de servicios, por el vertimiento de afluentes contaminantes conducidos por la red de servicios públicos y arrojados fuera de dicho perímetro, según el grado de materias contaminantes no eliminadas con que se haga el vertimiento.

En igual sentido, el marco legal de las áreas metropolitanas fue actualizado mediante la ley 1625 de 2013, la cual precisa en su artículo $7^{\circ}$ las funciones de las Áreas Metropolitanas en armonía con lo establecido en el artículo 319 de la Constitución Política, que precisa: Son funciones "Ejercer las funciones y competencias de autoridad ambiental en el perímetro Urbano de conformidad a lo dispuesto en la ley 99 de 1993". En este mismo orden de ideas y en la norma enunciada, precisa que:

Artículo $9^{\circ}$. Parágrafo. En aras de asegurar la planificación ambiental del territorio metropolitano, las Áreas Metropolitanas que ejerzan la competencia de autoridad 
ambiental, podrán establecer comisiones conjuntas para la regulación y administración de los ecosistemas o cuencas compartidas con otras autoridades ambientales. Artículo 20. Atribuciones Básicas de la Junta Metropolitana. La Junta Metropolitana tendrá las siguientes atribuciones básicas: d) Recursos naturales, manejo y conservación del ambiente. Adoptar en el centro urbano de los municipios de su jurisdicción, un plan metropolitano para la protección de los recursos naturales y defensa del ambiente, de conformidad con las disposiciones legales y reglamentarias sobre la materia; entre otros artículos con esencia ambiental. (Colombia, Congreso Nacional de la República, 2013)

Se concluye que en relación con las áreas metropolitana y los grandes centros urbanos, solo pueden ejercer la función de autoridad ambiental si cumplen con el requisito poblacional de igual o superior de un millón de habitantes ubicados en el área urbana del municipio o del área metropolitana; ya revisando la realidad ejercen autoridad ambiental urbana con las mismas funciones asignadas a las corporaciones autónomas regionales con fundamento en esta normativa Bogotá (Secretaría de ambiente), Medellín (área metropolitana), Bucaramanga (área metropolitana), entre otras.

El artículo 66 de la ley 99 de 1993, ha sido demandado ante la Corte Constitucional por afirmarse que está en contra de la Carta mayor, ya que la ley 99 de 1993, es una ley ordinaria y la Constitución Política afirma que para asignarle funciones a los municipios, como el caso concreto funciones de autoridad ambiental, debe ser bajo el techo de una ley orgánica; a diferencia de la reciente ley 1625 de 2013 sobre las áreas metropolitanas que si tiene la categoría de ley orgánica, pero en ésta se desperdició la oportunidad de haber absorbido el contenido del artículo 66 de la ley 99 de 1993.

La Constitución Política, en sus artículos 151 y 288, establece que las leyes relativas a la distribución de competencias entre la Nación y las entidades territoriales, ostentan la categoría de leyes orgánicas. Sin embargo, como lo ha dicho la Corte Constitucional, cada una de las leyes orgánicas de que trata el artículo 151 Superior, debe ser objeto de una detallada y cuidadosa limitación, en el entendido de que una interpretación muy amplia del ámbito que se reserva a las leyes orgánicas, podría vaciar la competencia del legislador ordinario y, en esa medida, restringir el principio democrático que orienta el Estado Social de Derecho que nos rige. Mientras no 
exista sentencia de inexequibilidad, seguirá gozando de legalidad y continuaran ejerciendo como autoridades ambientales los grandes centros urbanos.

\subsection{De los Municipios y Concejos Municipales}

Los municipios no ejercen funciones de autoridad ambiental, salvo si cumple con los requisitos del artículo 66 de la ley 99 de 1993 y los distritos especiales como ya se explicó anteriormente. Los municipios como entidad fundamental de la división político-administrativa del Estado, si les corresponde ejercer funciones ambientales en los casos señalados de nuestra Carta política, puntualmente en lo definido en el artículo 313 numeral 9 "Dictar las normas necesarias para el control, la preservación y defensa del patrimonio ecológico y cultural del municipio" y de igual forma, de conformidad con lo establecido en el artículo 65 de la ley 99 de 1993, le corresponde en materia ambiental, las siguientes atribuciones especiales:

Promover y ejecutar programas y políticas nacionales, regionales y sectoriales en relación con el medio ambiente y los recursos naturales renovables; elaborar los planes programas y proyectos regionales, departamentales y nacionales. Dictar las normas necesarias para el control, la preservación y la defensa del patrimonio ecológico del municipio. Adoptar los planes, programas y proyectos de desarrollo ambiental y de los recursos naturales renovables, que hayan sido discutidos y aprobados a nivel regional, conforme a las normas de planificación ambiental. Participar en la elaboración de planes, programas y proyectos de desarrollo ambiental y de los recursos naturales renovables a nivel departamental. Colaborar con las Corporaciones Autónomas Regionales, en la elaboración de los planes regionales y en la ejecución de programas, proyectos y tareas necesarios para la conservación del medio ambiente y los recursos naturales renovables.

Ejercer, a través del alcalde como primera autoridad de policía con el apoyo de la Policía Nacional y en coordinación con las demás entidades del Sistema Nacional Ambiental (SINA), funciones de control y vigilancia del medio ambiente y los recursos naturales renovables. Coordinar y dirigir, con la asesoría de las Corporaciones Autónomas Regionales, las actividades de control y vigilancia ambientales que se realicen en el territorio del municipio con el apoyo de la fuerza pública, en relación con la movilización, procesamiento, uso, aprovechamiento y comercialización de los recursos naturales renovables o con actividades contaminantes y degradantes de las aguas, el aire o el suelo. 
Dictar las normas de ordenamiento territorial del municipio y las regulaciones sobre usos del suelo. Ejecutar obras o proyectos de descontaminación de corrientes o depósitos de agua afectados por vertimiento del municipio, así como programas de disposición, eliminación y reciclaje de residuos líquidos y sólidos y de control a las emisiones contaminantes del aire. Promover, cofinanciar o ejecutar, en coordinación con los entes directores y organismos ejecutores del Sistema Nacional de Adecuación de Tierras y con las Corporaciones Autónomas Regionales, obras y proyectos de irrigación, drenaje, recuperación de tierras, defensa contra las inundaciones y regulación de cauces o corrientes de agua, para el adecuado manejo y aprovechamiento de cuencas y micro-cuencas hidrográficas.

En desarrollo normativo sobre el tema la ley 388 de 1997, determinó la responsabilidad en los municipios de realizar los planes de ordenamiento territorial.

De otra parte, la ley 136 de 1994 por medio de la cual se dictan normas tendientes a modernizar la organización y el funcionamiento de los municipios, consagra en el artículo $3^{\circ}$, como funciones de los municipios:

Planificar el desarrollo económico, social y ambiental de su territorio, y en coordinación con otras entidades. Solucionar las necesidades insatisfechas de salud, educación, saneamiento ambiental, agua potable, y Velar por el adecuado manejo de los recursos naturales y del medio ambiente.

Y entrado al campo de derecho penal, la ley 906 de 2004 "Nuevo Código de Procedimiento Penal", en su artículo 202, consagra que ejercen permanentemente funciones especializadas de policía judicial dentro del proceso penal y en el ámbito de su competencia, los alcaldes municipales. Facultad que es desconocidas para ciertos administradores municipales.

Es así, como se deduce que los municipios debe estar en permanente coordinación con las autoridades ambientales regionales, primero por ser el alcalde municipal integrante del consejo directivo de las CAR, y segundo por tener funciones conexas y articuladas, entre ellas, la destinación y usos del suelo (concertación con la autoridad ambiental, excepto lo dispuesto en el artículo 91 de la ley 1753 de 2015 -PND-), la delimitación y declaración de áreas protegidas del orden local, la gestión del riesgo, entre otras. Y como propuesta de la presente investigación, desarrollar la función de los entes territoriales de realizar la planificación en el manejo y aprovechamiento de los recursos naturales ubicados en el municipio respectivo. 


\subsection{Otras Entidades que Ejercen Funciones Ambientales}

No todas las entidades que tienen funciones ambientales asignadas por la Constitución Política, las leyes, los decretos y los acuerdos distritales o municipales son autoridades ambientales; definiendo el concepto de Autoridad Ambiental para Colombia, así: son entidades públicas que tienen la facultad de realizar la planificación ambiental, expedir permisos, licencias y autorizaciones ambientales, realizar el respectivo seguimiento, vigilancia, control y ser titular de la potestad sancionatoria en materia ambiental enfocado al desarrollo sostenible moderno en su jurisdicción.

\subsubsection{De la Procuraduría General de la Nación}

Una situación diferente se observa frente a las funciones ambientales asignadas a los entes territoriales disímiles a la de los órganos de control; pues es predicable su función preventiva, control de gestión, de protección y defensa de los derechos humanos, y disciplinaria. Y, es como la Constitución Política ha preceptuado en el artículo 277, que el Procurador General de la Nación, por sí o por medio de sus delegados y agentes, tendrá entre otras, las siguientes funciones $\mathrm{N}^{\circ} 4$ "Defender los intereses colectivos, en especial el ambiente" y de forma adyacente podrá "Intervenir en los procesos y ante las autoridades judiciales o administrativas, cuando sea necesario en defensa del orden jurídico, del patrimonio público, o de los derechos y garantías fundamentales".

Con fundamento en lo señalado en el decreto ley 262 de 2000, se le asignaron funciones preventivas, de control y protección a las Procuradurías Delegadas y Judiciales, entre ellas, la de intervenir ante las autoridades públicas, cuando sea necesario para defender el orden jurídico, el patrimonio público, las garantías y los derechos fundamentales, sociales, económicos, culturales, colectivos o del ambiente, así como los derechos de las minorías étnicas (artículo 24). De igual forma, le corresponde a las Procuradurías delegadas:

Interponer acciones populares, de tutela, de cumplimiento y las demás que resulten conducentes para asegurar la defensa del orden jurídico, en especial las garantías y los derechos fundamentales, sociales, económicos, culturales, colectivos o del ambiente, así como los derechos de las minorías étnicas. (Artículo 26 y 38 Ibídem); Intervenir, como Ministerio Público, en las actuaciones y ante las autoridades administrativas y de policía, 
cuando sea necesario para defender el orden jurídico, el patrimonio público, las garantías y los derechos fundamentales, sociales, económicos, culturales, colectivos o del ambiente, así como los derechos de las minorías étnicas (Artículo 27); Intervenir en el trámite especial de tutela ante cualquier autoridad judicial, cuando sea necesario en defensa del orden jurídico, del patrimonio público o de los derechos y garantías fundamentales, sociales, económicos, culturales, colectivos o del ambiente (Parágrafo - Artículo 28), Intervención judicial en procesos civiles y agrarios. (Artículo 31)

Los procuradores judiciales con funciones de intervención en los procesos civiles actuarán ante las salas civiles de los Tribunales Superiores de Distrito Judicial, los juzgados civiles de circuito y municipales, los tribunales de arbitramento que conozcan procesos civiles y demás autoridades que señale la ley, cuando sea necesario para defender el orden jurídico, el patrimonio público, las garantías y derechos fundamentales, individuales, colectivos o del ambiente. (Artículo 45 Ibídem), entre otras.

De otra parte, la ley 906 de 2004 “Nuevo Código de Procedimiento Penal”, en su artículo 202, consagra que ejercen permanentemente funciones especializadas de policía judicial dentro del proceso penal y en el ámbito de su competencia la Procuraduría General de la Nación.

\subsubsection{De la Defensoría del Pueblo - Personero Municipal}

La Defensoría del Pueblo y las Personerías Municipales son organismos que forma parte del Ministerio Público; ejerce sus funciones bajo la dirección del Procurador General de la Nación y le corresponde esencialmente velar por la promoción, el ejercicio y la divulgación de los derechos humanos.

Tomando como base lo expuesto en el artículo 282, numerales $1^{\circ}$ y $5^{\circ}$ Constitucionales, se afirma que es función del Defensor del Pueblo, Orientar e instruir a los habitantes del territorio nacional y a los Colombianos en el exterior en el ejercicio y defensa de sus derechos ante las autoridades competentes o entidades de carácter privado e Interponer acciones populares en asuntos relacionados con los derechos colectivos, como el derecho a un ambiente sano.

El decreto ley 25 de 2014, señala en su artículo $5^{\circ}$, las atribuciones de la Defensoría del Pueblo, entre otras, Difundir el conocimiento de la Constitución Política de Colombia, especialmente los derechos fundamentales, sociales, económicos, culturales, colectivos y del 
ambiente (numeral 6); y ser mediador de las peticiones colectivas formuladas por organizaciones cívicas o populares frente a la administración pública, cuando aquéllas lo demanden (numeral 11).

El Defensor del Pueblo podrá delegar sus funciones, en los Directores Nacionales, en los Defensores Delegados, en los Defensores Regionales, en los Personeros Municipales (parágrafo 1, artículo 5 Ibídem).

\subsubsection{De la Contraloría General de la Republica}

El artículo 267 de la Constitución Política de Colombia, determina que la Contraloría General tiene como función pública ejercer la vigilancia de la gestión fiscal de la administración y de los particulares o entidades que manejen fondos o bienes de la Nación.

De otra parte, el artículo 268 (Ibídem) determina que son atribuciones del Contralor General de la Republica, entre otras: "Presentar al Congreso de la República un informe anual sobre el Estado de los recursos naturales y del ambiente" (numeral $7^{\circ}$ ) y Promover ante las autoridades competentes, aportando las pruebas respectivas, investigaciones penales 0 disciplinarias contra quienes hayan causado perjuicio a los intereses patrimoniales del Estado (Numeral $8^{\circ}$ ).

En sentido estricto, es significativo enunciar que la ley 906 de 2004 "Nuevo Código de Procedimiento Penal", en su artículo 202, consagra que ejercen permanentemente funciones especializadas de policía judicial dentro del proceso penal y en el ámbito de su competencia la Contraloría General de la República.

\subsubsection{De la Fiscalía General de la Nación - CTI}

La Fiscalía General de la Nación emerge e inicia en 1991, con la promulgación de la nueva Constitución Política y empezó a operar el primero (01) de julio de 1992; como una entidad de la Rama Judicial del poder público, cuya función está orientada a brindar a los ciudadanos una cumplida y eficaz administración de justicia.

De conformidad con el artículo 114 de la ley 906 de 2004 (Código de Procedimiento Penal), enmarca Atribuciones de la Fiscalía General de la Nación, entre otras: Investigar y acusar 
a los presuntos responsables de haber cometido un delito; ordenar registros, allanamientos, incautaciones e interceptaciones de comunicaciones, y poner a disposición del juez de control de garantías los elementos recogidos, para su control de legalidad dentro de las treinta y seis (36) horas siguientes; asegurar los elementos materiales probatorios y evidencia física, garantizando su cadena de custodia.

En este mismo sentido, la ley 906 de 2004 "Nuevo Código de Procedimiento Penal” en su artículo 201, constriñe que ejercen permanentemente las funciones de policía judicial los servidores investidos de esa función, pertenecientes al Cuerpo Técnico de Investigación de la Fiscalía General de la Nación, a la Policía Nacional, por intermedio de sus dependencias especializadas.

Teniendo en cuenta la configuración legal anteriormente precedida, es aquí donde inicia la importancia de los delitos penales ambientales (ley 1453 de 2011, artículo 29 - 39); entre

ellos, la contaminación ambiental, el punible de daño a los recursos naturales, violación de fronteras para la explotación de recursos naturales, ilícito aprovechamiento de los recursos naturales renovables, invasión de áreas protegidas, pesca y caza ilegal, entre otros.

A hoy ya corren con la fuerza probatoria por parte de las autoridades ambientales para que con el acompañamiento de la Fiscalía y Policía ambiental, conforme grupos elites (GEA, GIRA, UIGA, etc.) para adelantar operativos de reacción inmediata y realicen la captura a delincuentes ambientales, y con abogados que representan a las autoridades ambientales, deban realizar la defensa judicial de los recursos naturales renovables, y se constituyen como partes en los procesos penales desde la legalización de la captura hasta que se profieran las sentencias condenatorias y el resarcimiento de los daños y perjuicios ambientales.

\subsubsection{De las Entidades Adscritas y Vinculadas al Ministerio de Ambiente - MADS}

El Sector administrativo de ambiente y desarrollo sostenible está integrado por el Ministerio de Ambiente y Desarrollo Sostenible - MADS y las siguientes entidades adscritas y vinculadas:

Las entidades adscritas son: 
- Instituto de Hidrología, Meteorología y Estudios Ambientales (Ideam). Estando definido su naturaleza jurídica como un establecimiento público, y dentro de sus funciones, se encuentra las mediciones del clima y el análisis de los diferentes fenómenos climáticos.

- Fondo Nacional Ambiental, Fonam. Fondo con personería jurídica.

Las entidades vinculadas son:

- El Instituto de Investigaciones Marinas y Costeras "José Benito Vives de Andreis", Invemar.

- El Instituto de Investigación de Recursos Biológicos “Alexander von Humboldt”.

- El Instituto de Investigaciones Ambientales del Pacífico. “John von Neumann”.

- El Instituto Amazónico de Investigaciones Científicas, Sinchi.

Las entidades vinculadas están definidas como instituciones científicas y tecnológicas de acuerdo al tenor del decreto 3570 de 2011, su finalidad primordial es adelantar actividades de investigación, emisión de conceptos técnicos y elaboración de estudios como base para la toma de decisiones al Ministerio de Ambiente y Desarrollo Sostenible; entre ellos está el acompañamiento del Instituto de Investigación Von Humboldt a la delimitación de los ecosistemas de páramos en todo el país.

\subsubsection{De las Fuerzas Militares}

Las Fuerzas Militares están constituidas por el Ejército Nacional, la Armada Nacional y la Fuerza Aérea, que tienen como finalidad primordial la defensa de la soberanía, la independencia, la integridad del territorio nacional y del orden Constitucional. (Artículo 217 de la Constitución Nacional).

El artículo 103 de la ley 99 de 1993, determina que "Las Fuerzas Armadas velarán en todo el territorio nacional por la protección y defensa del medio ambiente y los recursos naturales renovables y por el cumplimiento de las normas dictadas con el fin de proteger el patrimonio natural de la Nación, como elemento integrante de la soberanía nacional. La Armada Nacional tendrá a su cargo el ejercicio de las funciones de control y vigilancia en materia ambiental y de los recursos naturales, en los mares y zonas costeras, así como la vigilancia, seguimiento y evaluación de los fenómenos de contaminación o alteración del medio marino. 
En atención a lo estipulado en el artículo 102 ibídem, un 20\% de los bachilleres seleccionados para prestar el servicio militar obligatorio, prestarán servicio ambiental. El servicio ambiental tiene por objeto prestar apoyó a las autoridades ambientales, a las entidades territoriales y a la comunidad, en la defensa y protección del medio ambiente y los recursos naturales renovables. Tendrá las funciones de: Educación ambiental, organización comunitaria para la gestión ambiental, prevención control y vigilancia sobre el uso del ambiente y los recursos naturales renovables. El servicio ambiental está dirigido por el Ministerio de Defensa en coordinación con el Ministerio de Ambiente, será administrado por las entidades territoriales y se validará como prestación del servicio militar obligatorio.

\subsubsection{De la Policía Nacional}

La Policía Nacional es un cuerpo armado, permanente, de naturaleza civil; cuyo fin primordial es el mantenimiento de las condiciones necesarias para el ejercicio de los derechos y libertades públicas, y para asegurar que los habitantes de nuestro país "Colombia" convivan en paz; contribuyendo a las necesidades de seguridad y tranquilidad pública, mediante un efectivo servicio, fundamentado en la prevención, investigación y control de los delitos y contravenciones, generando una cultura de solidaridad pública (artículo 218 de la Constitución Nacional y artículo 33 del decreto 1512 de 2000).

De igual manera y de conformidad con el artículo 101 de la ley 99 de 1993, la Policía Nacional tendrá un cuerpo especializado de policía ambiental y de los recursos naturales, encargado de apoyar a las autoridades ambientales, a los entes territoriales y a la comunidad, en $\underline{\text { la defensa y protección del ambiente y los recursos naturales renovables, }}$ y en las funciones y acciones de control y vigilancia previstas por la ley.

Este Cuerpo Especializado prestará su servicio con prioridad en las zonas de reserva, Parques Nacionales Naturales y en las áreas de especial importancia ecosistémica, y colaborará en las tareas educativas, promociónales y de prevención para el buen cuidado y respeto de la naturaleza. 


\subsection{Conclusiones del Capítulo}

Se observa una variedad de autoridades ambientales en nuestro país, cada una ejerciendo sus funciones en los respectivos territorios o jurisdicción de acuerdo a sus competencias; en este sentido la Corte Constitucional mediante sentencia C- 813 2009, afirmó que:

Al respecto, debe tenerse en cuenta que las autoridades ambientales son en el nivel nacional el Ministerio de Ambiente, en el nivel regional las Corporaciones Autónomas Regionales y el nivel local las autoridades ambientales de los grandes centros urbanos y distritos especiales Estos organismos, deben ejercer las funciones de evaluación, control y seguimiento ambiental de las actividades de exploración de los recursos naturales no renovables, así como de otras actividades, proyectos o factores que generen o puedan generar deterioro ambiental. Además, de los usos del agua, el suelo, el aire y los demás recursos naturales renovables. Estas funciones también comprenden la expedición de las respectivas licencias ambientales, permisos, concesiones, autorizaciones y salvoconductos. (Colombia, Sentencia, 2009)

Bajo el mismo enfoque encontramos unas entidades del orden nacional, regional y local que tienen funciones ambientales y otras que ejercen funciones de autoridad ambiental; es decir no todas las instituciones que tiene asignadas funciones ambientales ejercen autoridad ambiental; verbi gracia: el Ministerio de Ambiente y Desarrollo Sostenible para el concepto del autor es el rector de la gestión del ambiente y de los recursos naturales renovables, pero no es una autoridad ambiental, ya que después del año 2011 no tiene funciones sancionatorias, ni facultad de realizar seguimiento, trámites, ni otorgar permisos y licencias ambientales, pues estas funciones fueron asumidas por el ANLA.

Repítase una vez más, las entidades que tienen funciones ambientales, en los diferentes órdenes, así: NIVEL NACIONAL: Ministerio de Ambiente y Desarrollo Sostenible, Autoridad Nacional de Licencias Ambientales (Autoridad ambiental), Parques Nacionales Naturales (Autoridad ambiental), Procuraduría General de la Nación, Contraloría General de la República, Fiscalía General de la Nación, Armada y Policía Nacional. NIVEL REGIONAL: Corporaciones Autónomas Regionales (Autoridad ambiental), Departamentos y Asambleas departamentales. NIVEL LOCAL. Grandes Centros Urbanos y Áreas metropolitanas (Autoridad ambiental, siempre y cuando superen un millón de habitantes urbanos), Establecimientos Públicos de los 
Distritos Especiales de Cartagena, Barranquilla, Santa Marta y Buenaventura (Autoridad ambiental), Entes territoriales y Concejos municipales.

La Constitución Política precisa que los diferentes órganos del Estado tienen funciones separadas pero colaboran armónicamente para la realización de sus fines (art. $113 \mathrm{CP}$ ), y en materia ambiental, en general las competencias ambientales entre los distintos niveles territoriales son concurrentes y no exclusivas, así ha sido definido por la Corte Constitucional, mediante la sentencia C-221 de 1997, que precisa:

Así las cosas, para la Corte es claro que cuando el artículo 80 se refiere al deber del Estado de planificar el manejo de los recursos naturales a fin de garantizar su desarrollo sostenible, la norma Constitucional hace referencia no sólo a la Nación sino al conjunto de autoridades públicas, no sólo por cuanto es un deber que naturalmente se predica de todas ellas sino, además, porque específicamente la Carta consagra obligaciones ecológicas de otras entidades territoriales.

Por ejemplo, el artículo 313 señala que los concejos deben dictar las normas necesarias para la protección del patrimonio ecológico municipal, y el artículo 300 atribuye a las asambleas competencia para dictar normas ambientales. Por ello esta Corporación ya había establecido que en materia ambiental en general las competencias ambientales entre los distintos niveles territoriales son en general concurrentes y no exclusivas. (Colombia, Sentencia, 1997)

Tomando como base lo anteriormente expuesto en el presente capítulo, se afirma que existen diversas autoridades ambientales en Colombia, y al realizar la lectura de las funciones enunciadas a su cargo, se observa cierta omisión en el desarrollo efectivo de las funciones como autoridades ambientales; entre ellas, la obligación de planificar el manejo y aprovechamiento de los recursos naturales.

De igual forma, la estructura de las asambleas corporativas o consejos directivos al interior de las autoridades ambientales - Corporaciones Autónomas Regionales, tiene la posibilidad que determinados representantes no sean las personas más idóneas frente al tema ambiental, por no existir requisitos mínimos técnicos reglamentados para postularse a estos cargos, que conllevan la gran responsabilidad de velar por el cumplimiento de los deberes del 
Estado y de los particulares en materia ambiental y de proteger el derecho Constitucional a un ambiente sano de las personas; sin dejar a un lado, que a hoy, existe politización en ciertos órganos directivos, ya que en él tienen asiento un número de alcaldes y en algunas CAR es precedido por el gobernador de su jurisdicción.

Pero el tema se enfoca más a profundidad con la crisis de legitimidad de las autoridades ambientales, las cuales hoy es básico afirmar, que en su mayoría las corporaciones autónomas regionales el tema técnico viene desapareciendo y el tema ambiental pierde su importancia y está en un contexto secundario; la planificación estratégica ambiental debe ser el soporte de los planes de acción, la Carta de navegación de las autoridades ambientales en armonía con una reforma legislativa frente a esta materia.

Sin perjuicio de lo precedente, se puntualiza que "las normas ambientales son de orden público y no podrán ser objeto de transacción o de renuncia a su aplicación por las autoridades o por los particulares" (ley 99 de 1993, art. 107). En este sentido, y como vector de la presente investigación podemos determinar que existen cinco (5) entidades que ejercen funciones como autoridad ambiental en nombre del Estado y más de diez (10) instituciones que tiene asignadas líneas ambientales en diferentes aspectos, diferentes a la de ejercer autoridad ambiental.

Después de la lectura de casi doscientas funciones ambientales legales y en armonía con los pronunciamientos jurisprudenciales, se precisa que es obligación de la Nación y del conjunto de autoridades públicas dar cumplimiento a lo dispuesto en el artículo 80 de la Constitución Política, frente a la planificación en el manejo y aprovechamiento de los recursos naturales, para garantizar su desarrollo sostenible, empero no existe un sujeto activo directo; es decir en medio de tantas funciones "la planificación ambiental" no se vislumbra en el actuar de las entidades que ejercen la autoridad ambiental, no se encuentra una entidad o dependencia que asuma esta obligación Constitucional nacional, y como precedente, es la inexistencia de reglamentación legal vigente sobre el tema. El vació jurídico es visible. 


\section{CAPITULO TERCERO}

\section{LA PLANIFICACION AMBIENTAL}

Observado lo anterior, en este capítulo de estudio se planteará un modelo conceptual que sirve como referente para el marco legal reglamentario, permitiendo establecer el cumplimiento y aplicación de la planificación en el manejo y aprovechamiento de los recursos naturales como precepto Constitucional dentro de la responsabilidad ambiental Estatal.

Para llegar a tal fin, partiremos de los antecedentes y espíritu del artículo 80 Constitucional consignados en la Asamblea Nacional Constituyente, seguido la individualización de ciertas leyes, decretos, jurisprudencias y proyectos de ley radicados o en curso sobre la planificación ambiental, su utilidad, alcance o finalidad, y temas afines a la investigación (contexto interno), para continuar con la identificación del pensamiento de ciertas organizaciones del mundo (contexto externo), a fin de plantear una solución, que sirve de propuesta estructural fundada sobre una problemática ambiental presente y el cumplimiento de un mandato Constitucional, orientado a alcanzar el desarrollo sostenible moderno.

\subsection{Contexto Interno sobre la Planificación Ambiental}

Después de haber recorrido cada uno de los axiomas ambientales, quedó comprobada la obligación Constitucional por parte de la Nación y del conjunto de autoridades públicas de realizar la planificación en el manejo y aprovechamiento de los recursos naturales; así mismo, la función ecológica que tiene como carga la propiedad privada y la función social y ambiental que deben cumplir las personas jurídicas y naturales.

Es por ello, que se realizó la identificación legal de las autoridades ambientales y de sus funciones, quedando indicado que la "planificación ambiental" propiamente dicha, no tiene un marco legal reglamentario y no coexiste como titular institucional una autoridad pública exclusiva, que responda por el cumplimiento estricto a lo dispuesto en el artículo 80 de la Constitución Política de Colombia. 


\subsubsection{Nacimiento de la Planificación Ambiental en Colombia.}

Inicia la presente historia de cómo emergió lo consignado en el artículo 80 de la Constitución Política de Colombia, la cual quedo publicada en los siguientes términos:

El Estado planificará el manejo y aprovechamiento de los recursos naturales, para garantizar su desarrollo sostenible, su conservación, restauración o sustitución. Además, deberá prevenir y controlar los factores de deterioro ambiental, imponer las sanciones legales y exigir la reparación de los daños causados. Así mismo, cooperará con otras naciones en la protección de los ecosistemas situados en las zonas fronterizas. (Constitución Política, 1991)

Tiene su partida el día lunes 15 de abril de 1991 en el marco de la Asamblea Nacional Constituyente, liderada por sus tres Presidentes (Antonio Navarro Wolff, Horacio Serpa y Álvaro Gómez Hurtado), en la cual se radica el "Informe de Ponencia Medio Ambiente y Recursos Naturales", siendo designados los señores: Marulanda Iván, Perry Guillermo, Benítez Jaime, Garzón Angelino, Cuevas Tulio y Guerrero Guillermo. Consignado lo anterior en la Gaceta Constitucional $\mathrm{N}^{\circ} 46$.

En este informe de ponencia se expusieron (I) Los antecedentes, (II) El medio ambiente en los proyectos y propuestas de reforma Constitucional que fueron presentados ante la Asamblea Nacional Constituyente y (III) El articulado especifico propuesto sobre medio ambiente; dentro de los antecedentes, centra su importancia las siguientes afirmaciones:

La preocupación por los impactos de la actividad humana sobre el medio se inició durante el siglo pasado y la primera mitad del presente con los movimientos conservacionistas... Después de la Segunda Guerra Mundial se incrementó la precepción de la crisis ambiental, enfocada desde las diferentes disciplinas cientificas... la preocupación llegó hasta el seno de las Naciones Unidas que convocó la Conferencia Internacional de Estocolmo sobre el Medio Ambiente Humano en 1972.

Dos años más tarde se creó el Programa de Naciones Unidas para el Medio Ambiente (PNUMA) y se empezaron a establecer administraciones ambientales a nivel nacional. Hoy en día la mayor parte de los países industrializados cuentan con ministerios ambientales y con estrictas leyes que regulan todas las actividades relacionadas con la trasformación del medio. Los países que han dictado constituciones en los últimos años, como el Brasil, han 
incorporado en ellas la dimensión ambiental. El planeta se prepara para celebrar en 1992 la Conferencia Internacional sobre Medio Ambiente y Desarrollo, que posiblemente cambiará en muchos aspectos el rumbo actual del crecimiento.

Colombia no ha permanecido aislada de este contexto. A imitación del TVA establecido en Estados Unidos..., se creó la CVC en 1954. El Instituto de Recursos Naturales se estableció a nivel nacional antes de la Conferencia de Estocolmo y dos años después de ella se aprobó el Código de Recursos Naturales (Decreto 2811 de 1974). Con anterioridad se habían promulgado el Estatuto Forestal (Acuerdo 3 de 1969) y el Acuerdo 42 de 1971, sobre Parques Nacionales. En 1979 se promulgó la ley Sanitaria Nacional (ley 9 de 1979) y el nuevo Código Penal, promulgado en 1980, sancionó por primera vez los delitos contra el Medio Ambiente. En 1987, la Procuraduría General de la Nación adscribe la vigilancia de los aspectos ambientales a la Procuraduría Delegada para los Asuntos Agrarios.

Durante los últimos dos años se han venido proponiendo diversos proyectos para la restructuración del Sector Ambiental en la Administración Pública.... La unificación tecnológica y cultural del mundo ha engendrado la conciencia de la unidad de los procesos vivos. El problema ambiental es posiblemente uno de los mayores movilizadores de la conciencia pública en este final de siglo.... Gran parte de los problemas ambientales del país son generados por la carencia de oportunidades productivas... La deforestación ha superado durante los últimos decenios el medio millón de hectáreas por año. Los mejores bosques del área andina han sido talados.

El desarrollo de la agricultura no ha logrado la autosuficiencia alimentaria.... Ha venido afectando gravemente el medio ambiente y la salud.... En la perspectiva del futuro desarrollo, la mayor riqueza que pueden presentar los países del trópico es su alta diversidad genética.... Es urgente establecer las medidas necesarias a nivel nacional e internacional para preservar las cuencas de los bosques tropicales de una temprana y fatal desaparición.... El problema ambiental no impone tanto un límite al desarrollo como una reorientación del mismo.... Como lo expresan las conclusiones del Seminario Latinoamericano sobre Universidad y Medio Ambiente (Bogotá, 1985): "El ambiente de nuestros países debe entenderse como un potencial para un desarrollo alternativo a partir de la movilización de los recursos humanos, ecológicos, y culturales de la región para dar sentido y fuerza productiva a una racionalidad ambiental de desarrollo igualitario, más productivo y sostenible a largo plazo". 
Es su deber promover el manejo y aprovechamiento de los recursos naturales para conseguir el desarrollo y mejorar la calidad de vida de las generaciones presentes, pero al mismo tiempo, su manejo y aprovechamiento deben ser racionales.... Esta formulación corresponde hoy en día generalizado de desarrollo sostenible o sustentable: el desarrollo económico y social debe hacerse compatible con la preservación del medio ambiente, para asegurar el sostenimiento del progreso a largo plazo.... Se pretende, entonces, sentar el principio de que le aprovechamiento económico de los recursos naturales ha de generar los recursos financieros necesarios para desarrollar la gestión ambiental, para garantizar la renovabilidad de los recursos potencialmente renovables y para que se puedan desarrollar sustitutos de aquellos que son agotables.

Varios de los proyectos y propuestas sugieren que las normas sobre planeación económica hagan expreso que los planes tanto nacionales como regionales y locales, deben contener un componente de la planeación de la gestión ambiental y del aprovechamiento de los recursos naturales. Los ponentes acogen esta recomendación y así lo sugieren a la Comisión para que se tenga en cuenta al momento de discutir el tema de la planeación. (Asamblea Nacional Constituyente, 1991)

Lo expresado, evidentemente deja al descubierto la debilidad o ausencia de preceptos constitucionales ambientales antes de 1991; y es en este sentido, posterior a la presentación del informe de ponencia sobre el medio ambiente y los recursos naturales, la continuidad con el trámite una vez acogida la planificación ambiental por parte de la Comisión a fin de consolidarse como artículo Constitucional. Devino en la sesión plenaria de mayo 20 de 1991 y quedando en el orden del día la votación del articulado de medio ambiente, siendo consignado en la Gaceta Constitucional $\mathrm{N}^{\circ} 103$ del 20 de junio de 1991, página 14 y 15 sustitutiva $\mathrm{N}^{\circ} 5$, artículo $2^{\circ}$ quedando aprobada la obligación del Estado de realizar la planificación en el manejo y aprovechamiento de los recursos naturales.

En tal virtud, el articulado ambiental tuvo trámite por parte de la Comisión Quinta en mayo 24 de 1991, quedando aprobado y consignado en la Gaceta Constitucional № 83 de mayo 27 de 1991, página 34; y mantuvo su vigencia el postulado de la planificación ambiental. Artículo $2^{\circ}$ aprobado con pequeñas modificaciones en su redacción.

Es necesario precisar, que en la Gaceta constitucional $N^{\circ} 109$ de 27 de junio de 1991 página 8 , capítulo $6^{\circ}$ "Ecología y medio ambiente", quedó consignado un artículo sin 
numeración, respecto a la planificación ambiental por parte del Estado. Y en este mismo sentido se entró a considerar en sesión plenaria - segundo debate, el capítulo sobre los derechos colectivos y del ambiente consignado en la Gaceta Constitucional $\mathrm{N}^{\circ} 142$ de fecha 28 de junio de 1991 en su página 18, quedando numerado como artículo 81, así: "El Estado planificará el manejo y aprovechamiento de los recursos naturales....", fue aprobado con resultado de cincuenta (50) votos afirmativos al interior de la Asamblea Nacional Constituyente.

Al igual, que en la Gaceta Constitucional No 113 de julio 05 de 1991, se estipuló el artículo 81 sobre el tema de investigación "La planificación ambiental"; y en la Gaceta Constitucional del 10 de octubre de 1991, en su artículo 80 se enunció el tema aludido. En este ejercicio de la identificación de la génesis y los antecedentes del artículo 80 Constitucional, se evidenció la necesidad sentida por parte del Estado de llevar a la ratio Constitucional el precepto de la planificación ambiental, como obligación de la Nación y de las autoridades públicas.

\subsubsection{Definición, Utilidad y Finalidad de la Planificación Ambiental}

En gracia de análisis, y después de dos años de publicado el Estatuto Constitucional (1991), se profiere la ley 99 de 1993, la cual dio origen al Ministerio del Medio Ambiente (Hoy, Ministerio de Ambiente y Desarrollo Sostenible) y para el manejo ambiental de Colombia, se estableció y organizó el Sistema Nacional Ambiental - SINA, definido como "el conjunto de orientaciones, normas, actividades, recursos, programas e instituciones que permiten la puesta en marcha de los principios generales ambientales".

El SINA se encuentra orientado intrínsecamente a la planificación ambiental; lo precedente, se deduce de la lectura de la interrelación de sus componentes que "definen los mecanismos de actuación del Estado y la sociedad civil” (art. $1^{\circ} \mathrm{N}^{\circ} 13 \mathrm{y} 4^{\circ}$ ).

De igual forma, la ley en comento, en su artículo $1^{\circ}$ precisó que la política ambiental Colombiana seguirá unos principios generales, entre ellos:

12. El manejo ambiental del país, conforme a la Constitución Nacional, será descentralizado, democrático, y participativo. Y, 14. Las instituciones ambientales del Estado se estructurarán teniendo como base criterios de manejo integral del medio ambiente y su interrelación con los procesos de planificación económica, social y física. 
Continuando con la línea de la investigación, previa lectura de los objetivos y las funciones asignadas al Ministerio de Ambiente y Desarrollo Sostenible - MADS fijadas en el decreto 3570 de 2011, en cotejo con la función consagrada en el artículo 80 de la Constitución Política asignada al Estado en planificar el manejo y aprovechamiento de los recursos naturales; podemos afirmar que se observan aproximaciones en las funciones y objetivos del Ministerio de Ambiente, pero no se vislumbra una función específica frente al tema Constitucional de realizar un diagnóstico e inventario de los recursos naturales renovables de la Nación como fase previa de la planificación ambiental; y es aquí donde surgen unos interrogantes: Que se entiende por planificación ambiental, como la ha definido la Corte Constitucional, cuál es su alcance, enfoque y finalidad. Al respecto ampliaremos el tema, así:

\subsubsection{1 ¿En qué consiste la Planificación ambiental? Definición}

De acuerdo a lo dispuesto en el artículo $7^{\circ}$ del decreto 1768 de 1994, define la planificación ambiental como:

La herramienta prioritaria y fundamental para el cumplimiento de los objetivos de las corporaciones y para garantizar la continuidad de las acciones. Deberá realizarse de manera armónica y coherente con los planes regionales y locales. Para tal fin, las corporaciones elaborarán planes y programas a corto, mediano y largo plazo y en los estatutos respectivos se establecerán los mecanismos de planificación y los que permitan evaluar su cumplimiento.

Nótese, que la presente norma define la planificación ambiental exclusivamente para las Corporaciones Autónomas Regionales, es decir, nos estamos centrando en una planificación ambiental regional, lo precedente en armonía con lo dispuesto en el decreto 1200 de 2004 sobre el plan de gestión ambiental regional - PGAR y el plan de acción trienal - PAT, hoy vigentes; en un sentido más amplio, el autor se permite definir la planificación ambiental, así:

Es un instrumento de gestión de las autoridades públicas con funciones ambientales, que lleva implícito la obligación de realizar un inventario de la existencia de los recursos naturales renovables, su manejo integral y utilización sostenible prolongado en el tiempo, manteniendo su equilibrio ecológico. 
Lo anterior en armonía con la interrelación de los procesos de planificación económica y social, y lo dispuesto en la sentencia C-495 de 1996, donde la Corte Constitucional sostuvo:

La planificación ambiental debe responder a los dictados de una política nacional, la cual se adoptará con la participación activa de la comunidad y del ciudadano, y la misma debe ser coordinada y articulada entre la Nación y las entidades territoriales correspondientes. El derecho a gozar de un ambiente sano les asiste a todas las personas, de modo que su preservación, al repercutir dentro de todo el ámbito nacional -e incluso el internacional-, va más allá de cualquier limitación territorial de orden municipal o departamental. (Colombia, Sentencia, 1996)

En efecto, el Estado es quien tiene la obligación de proteger los recursos naturales renovables, la vida, y por su parte la Corte Constitucional, mediante sentencia C-535 de 1996, se pronunció en términos similares, afirmando:

En principio, su carácter global e integrado y la interdependencia de los distintos ecosistemas hacen del medio ambiente un asunto de interés nacional, y por lo tanto la responsabilidad en esta materia está radicada prima facie en el Estado central (CP. arts. 79 inc. 2 y 8). (Colombia, Sentencia, 1996)

No sobra mencionar en la presente investigación que la planificación ambiental definida como obligación Estatal en el artículo 80 de la Constitución Política tuvo resorte de análisis en la Corte Constitucional; y es el caso contemplado en la sentencia C-423 del 29 de septiembre de 1994, quedado evidenciado que su desarrollo legislativo y real en el contexto ambiental ha sido mínimo, por ende las constantes afectaciones de los recursos naturales renovables en todo el territorio nacional, así:

La planificación ambiental debe responder a los dictados de una política nacional, la cual se adoptará con la participación activa de la comunidad y del ciudadano, y la misma debe ser coordinada y articulada entre la Nación y las entidades territoriales correspondientes.

La Carta Política le otorga al Estado la responsabilidad de planificar y aprovechar los recursos naturales de forma tal que se logre un desarrollo sostenible, garantizando así la conservación y la preservación del entorno ecológico. Al respecto, cabe recordar que el derecho a gozar de un ambiente sano les asiste a todas las personas, de modo que su preservación, al repercutir dentro de todo el ámbito nacional -e incluso el internacional-, va 
más allá de cualquier limitación territorial de orden municipal o departamental. (Colombia, Sentencia, 1994)

Dentro de este orden de ideas, y siguiendo la línea jurisprudencial de la honorable Corte Constitucional y con la finalidad de explorar respecto de la planificación en el manejo y aprovechamiento de los recursos naturales renovables desde la órbita Nacional, a través de la sentencia C-894 de 2003, se precisó:

De lo anterior se tiene entonces, que el sistema constitucional de protección del medio ambiente tiene dos características orgánicas principales. En primer lugar, tiene un diseño abierto funcionalmente, lo cual permite la concurrencia de competencias entre la Nación, las Corporaciones autónomas regionales, las entidades territoriales, y las autoridades indígenas. En segundo lugar, teniendo en cuenta el carácter unitario del Estado colombiano, y una característica importante del bien jurídico objeto de protección (interdependencia de los ecosistemas), califican la protección del medio ambiente como un asunto de interés nacional. En esa medida, la responsabilidad por su protección está en cabeza de las autoridades nacionales. Sin embargo, también a las entidades regionales y territoriales les corresponde un papel importante en el sistema de protección del ambiente.

En algunos artículos la Carta atribuye responsabilidades al Estado, sin especificar a qué órgano o en qué orden le corresponde cumplirlas, mientras en otros establece funciones a entidades determinadas. De tal modo, por ejemplo, el artículo $8^{\circ}$ establece la obligación del Estado de proteger las riquezas naturales, sin especificar a qué órgano le corresponde tal función. Por su parte, el artículo 80 dispone que el Estado debe planificar el manejo y aprovechamiento de los recursos naturales para garantizar su desarrollo sostenible, su conservación, restauración o sustitución, que debe prevenir y controlar los factores de deterioro ambiental, imponer las sanciones legales y exigir la reparación de los daños. Sin embargo, en dicho artículo tampoco se radican competencias en cabeza de una autoridad específica. (Colombia, Sentencia, 2003)

De igual manera, en el mismo fallo (C-894 de 2003) la Corte Constitucional dejó plasmado respecto del artículo $80 \mathrm{CP}$, que "un adecuado manejo y aprovechamiento de los recursos naturales requiere que el Estado cuente con instrumentos que le permitan prevenir y controlar los factores de deterioro ambiental. Uno de tales mecanismos lo constituye la facultad del Estado (...), exigiendo licencias ambientales". 
Diferente a referirnos sobre la planificación del territorio u ordenamiento territorial; el Estatuto Constitucional precisa es sobre la planificación en el manejo y aprovechamiento de los recursos naturales y no sobre la planificación territorial, que puede ser una parte, pero no el todo.

Tanto el ordenamiento territorial como el Sistema Nacional de Cambio Climático están intimamente relacionados con el sistema ambiental, siendo los ecosistemas la base del desarrollo sostenible y entendiendo que los servicios ecosistémicos soportan y protegen todas las actividades humanas. (Quijano, Henry. Konrad Adenauer Stiftung, 2012, p. 61)

En este sentido, se observa que se desvía la atención y pierde su origen esencial respeto a la función asignada al Ministerio de Ambiente y Desarrollo Sostenible - MADS, en comparación con la planificación ambiental Constitucional, así: la función asignada mediante el decreto $\mathrm{N}^{\circ}$ 3570 de 2011 al Ministerio (MADS) es “diseñar y formular la política nacional en relación con el ambiente y los recursos naturales renovables, y establecer las reglas y criterios de ordenamiento ambiental de uso del territorio y de los mares adyacentes, para asegurar su conservación y el aprovechamiento sostenible de los recursos naturales renovables y del ambiente"; se vislumbra que es una aproximación, pero no es la reglamentación a lo estipulado en la Constitución Política (art. 80), en cuanto a que "el Estado planificará el manejo y aprovechamiento de los recursos naturales, para garantizar su desarrollo sostenible, su conservación, restauración o sustitución".

Si analizamos el párrafo precedente y realizamos la comparación normativa, encontramos que coexiste la similitud respecto a la finalidad de los dos preceptos (el legal y el Constitucional), así: "para asegurar su conservación y el aprovechamiento sostenible de los recursos naturales renovables y del ambiente" y "para garantizar su desarrollo sostenible, su conservación, restauración o sustitución”. Lo anterior, no tiene otro sentido diferente, que asegurar la vida humana.

Continuando con el estudio de la relación normativa enunciada anteriormente, se vislumbra que su base es diferente, y es aquí donde emerge la desviación de lo esencial, en este sentido: Por decreto se precisa que corresponde al Ministerio de Ambiente "establecer las reglas y criterios de ordenamiento ambiental de uso del territorio y de los mares adyacentes", y por precepto Constitucional corresponde al Estado la obligación de "planificar el manejo y 
aprovechamiento de los recursos naturales". Es así, que la obligación de la responsabilidad ambiental del Estado de planificar el manejo y aprovechamiento de los recursos naturales es el todo, y la función de ordenar el uso del territorio y los mares, es una parte de la planificación ambiental.

El ordenamiento del territorio atiende los procesos de cambio en el uso del suelo y de su adecuación al interés común; y no debemos olvidar que los recursos naturales renovables, incluyen el territorio (el suelo), pero además aglomeran el recurso agua (ordenamiento del recurso hídrico), los ecosistemas de protección (planificación para el manejo de los páramos), la fauna, flora (plan de ordenación forestal), recurso aire y paisaje; los cuales deben ser planificados, partiendo de un diagnóstico e inventario de lo que tenemos en cada uno de los recursos naturales renovables; para posteriormente, trazar políticas y regulaciones ambientales de ordenamiento, recuperación, conservación, protección, procurando su manejo, uso y aprovechamiento racional - sostenible.

Y es así, que del análisis legal realizado en los capítulos anteriores, se infiere que la planificación ambiental no es tenida en cuenta al momento de proferirse los permisos, licencias, concesión y autorizaciones ambientales, ya que los estudios de impacto ambiental o los diferentes documentos aportados dentro del trámite son evaluados sin norte ambiental definido.

Dentro de los trámites ambientales, se encuentran: Los permisos de emisiones atmosféricas, autorizaciones de poda, tala y reubicación, tenencia autorizada para fauna silvestre, salvoconductos de movilización para fauna y flora, concesiones de agua superficial y subterráneas, permisos de ocupación de cause, la obligatoriedad para ciertas empresas industriales de constituir o contar con los departamentos de gestión ambiental, licencias ambientales o plan de manejo ambiental para obras o proyectos, guías minero ambientales, permisos de vertimientos, lineamientos ambientales, permiso de investigación con fines científicos, programas de uso eficiente del agua, entre otros, y un régimen sancionatorio administrativo por incumplimientos a las normas ambientales y/o por las afectaciones a los recursos naturales renovables, incluso están tipificados los delitos ambientales en el Estatuto penal Colombiano. Lo precedente, sin desconocer que hoy contamos con el comparendo ambiental. 
Pertinente precisar que después de la Constitución Política de 1991, se han expedido un sin número de leyes y decretos en materia ambiental; día a día se profieren normas sobre el componente ambiental; es incalculable poder contarlas, parecería que estamos frente a un mar sin horizonte; entre las normas, expedidas se encuentran la ley 99 de 1993, ley 388 de 1997, ley 373 de 1997, ley 685 de 2001, ley 1333 de 2009, ley 1523 de 2012, ley 1638 de 2013 (Prohíbe exhibición de animales en los circos), ley 1753 de 2015 (Plan Nacional de Desarrollo 2014 2018); y así mismo, los decretos decreto 1768 de 1994, decreto 948 de 1995, decreto 1791 de 1996, decreto 883 de 1997, decreto 155 de 2004, decreto 1200 de 2004, decreto 3440 de 2004, decreto 3930 de 2010, decreto 1640 de 2012, decreto 2667 de 2012, decreto 2981 de 2013, decreto 2041 de 2014, decreto 783 de abril 21 de 2015, decreto 1076 de 2015 (Por el cual se compiló parte de la normativa ambiental); sin enunciar las resoluciones frente al tema.

Así mismo, no se debe obviar la normatividad vigente proferida con antelación a la Constitución Política de 1991, entre otras: Decreto ley 2811 de 1974, decreto 1541 de 1978, decreto 1608 de 1978, y decreto 1449 de 1979, entre otros.

Incoado el decreto - ley 2811 de 1974, por el cual se dicta el Código Nacional de Recursos Naturales Renovables y de Protección al Medio Ambiente, nos remitimos al artículo 316 que enuncia "Se entiende por ordenación de una cuenca la planeación del uso coordinado del suelo, de las aguas, de la flora y la fauna, y por manejo de la cuenca, la ejecución de obras y tratamientos".

Frente algunos instrumentos de planificación, ejecución y control en el marco normativo para las autoridades ambiental regionales, es trascendental identificarlos y de acuerdo a lo consagrado en el decreto 1200 de 2004 y ley 1263 de 2008, se enuncian: El presupuesto anual de rentas y gastos, el plan de acción por cuatro años (PAC), plan de gestión ambiental (PGAR) que tiene dentro de sus componentes un diagnóstico ambiental, la visión regional, líneas estratégicas y los instrumentos de seguimiento y evaluación; ahínco en afirmar, que los mencionados instrumentos aplica al plano de las autoridades ambientales regional (CAR) y no bajo un enfoque nacional.

En igual sentido, el decreto 1640 de 2012 "Por medio del cual se reglamentan los instrumentos para la planificación, ordenación y manejo de las cuencas hidrográficas y 
acuíferos" reguló la estructura y los instrumentos de planificación en la materia específica de las cuencas y temas asociados al recurso hídrico, y son:

\section{Planes Estratégicos en las Áreas Hidrográficas o Macrocuencas. 2. Programa Nacional} de Monitoreo del Recurso Hídrico, en las Zonas Hidrográficas. 3. Planes de Ordenación y Manejo de Cuencas Hidrográficas, en Subzonas Hidrográficas o su nivel subsiguiente. 4. Planes de Manejo Ambiental de Microcuencas, en las cuencas de nivel inferior al del nivel subsiguiente de la Subzona Hidrográfica, y 5. Planes de Manejo Ambiental de Acuíferos.

Otros instrumentos de manejo de los recursos naturales renovables, territorial y de gestión del riesgo en lo local y regional, son: Los planes de manejo de humedales, plan de manejo de páramos, planes de manejo integral de manglares, planificación, ordenación y manejo de cuencas hidrográficas y acuíferos, planes estratégicos de las áreas hidrográficas o macrocuencas, planes de ordenamiento del recurso hídrico - PORH y planes estratégicos, planes de saneamiento y manejo de vertimientos - PSMV, plan municipal o distrital para la gestión integral de residuos o desechos sólidos - PGIRS, planes de ordenamiento, manejo y aprovechamiento forestal, POT, PBOT, EOT, planes de gestión del riesgo de desastres, entre otros.

Se evidencia de no existir una planeación legislativa en materia ambiental, cada norma se profiere de acuerdo al tema de moda y ciertas son derogadas, modificadas, reglamentadas o declaradas inexequibles por ser contraria a la Constitución Política. Frente a este tema, si existiese una verdadera planificación en el manejo y aprovechamiento de los recursos naturales, tendríamos norte y brújula a nivel nacional; es al respecto, que nos permitimos recomendar la unificación, normativa ambiental, en armonía con la actualización y modernización del decreto ley 2811 de 1974, actual y vigente Código Nacional de los Recursos Naturales, que a hoy lleva cumplido cuarenta años de vigencia con una serie de modificaciones y el cual fue expedido antes de la Constitución verde de Colombia de 1991.

Frente a lo precedente y partiendo del contenido y avance logrado con el decreto 1056 de 2015, se recomienda elaborar y proferir el CUNA - CODIGO UNICO NACIONAL AMBIENTAL; resultado de la compilación y codificación de la normativa ambiental enunciada en cuerpo de la presente investigación, la política nacional ambiental para el desarrollo sostenible de los espacios oceánicos y las zonas costeras e insulares, la políticas de biodiversidad (1995), la política de Bosques (1996), la política de gestión integral de residuos sólidos (1997), la política 
de producción más limpia (1997), los lineamientos de política para la participación ciudadana en la gestión ambiental (1998), los lineamientos para la política nacional de ordenamiento ambiental del territorio (1998), la política nacional para la gestión integral del recurso hídrico (2010), la actualización normativa ambiental respectiva y la nueva reglamentación a proferirse enmarcada en la planificación del manejo y aprovechamiento de los recursos naturales (art. $80 \mathrm{CP}$ ), y enfocada al desarrollo sostenible moderno "la vida humana presente, como bien ecológico esencial".

De otra parte, resulta claro enunciar, que algunos funcionarios o contratistas investidos de autoridad ambiental en Colombia, no son efectivos para realizar evaluación, control y seguimiento en cumplimiento de sus funciones y actividades ambientales, otorgar permisos y aplicar el régimen sancionatorio a cada una de las empresas e industrias existentes; sin obviar que una sola factoría puede llegar a tener un sinnúmero de permisos o autorizaciones ambientales enunciados en anterior oportunidad.

Dentro de los principales protagonistas de la gestión del riesgo y del cambio climático se encuentran los funcionarios... Y estos actores tienen una gran responsabilidad que enfrentan, a menudo, en contextos de deficiencia o insuficiencia de información y capacidades, poca articulación institucional y escasez de recursos. (Konrad Adenauer Stifung, 2012, p. 9)

En segundo término, debe decirse que los tiempos en que puede durar un trámite ambiental, entre ellos, proferir una licencia ambiental y/o la duración de un proceso sancionatorio ambiental, desde el informe en que se evidencia la afectación ambiental, su apertura, formulación de cargos, pruebas y la resolución que profiere la sanción; pueden durar los anteriores procedimientos más de 24 o 36 meses, siendo contrario a los términos de ley. Sin desconocer, la falta de reacción inmediata de la autoridad ambiental frente a las quejas recibidas por daño en los recursos naturales, entre otras actividades. Surge una propuesta, y es suprimir algunas funciones a las autoridades ambientales nacionales, regionales y locales, y en este sentido, crear los JUECES AMBIENTALES y asignarles funciones judiciales en materia ambiental.

Bajo la anterior línea, serían las autoridades ambientales quienes realizaran los estudios técnicos de evaluación, seguimiento y control y los Jueces Ambientales, tendría la función de 
proferir sentencias para otorgar los permisos y autorizaciones ambientales y manejar el proceso administrativo sancionatorio; lo precedente, a fin de no repetir situaciones que atentan con nuestra vida, como la siguiente:

El anterior informe junto con el de la Procuraduría General de la Nación permite establecer criterios preliminares de que hay un alto impacto negativo ambiental en la zona de influencia de la explotación carbonífera de la Drummond Ltda. Así, en el informe de este organismos de control se señala los severos daños medioambientales que se han generado en 20 años de explotación de la zona, en los cuales se resalta la denuncia al cambio o desvío de importantes fuente hídricas, filtraciones, botadores de estériles y residuos sólidos de las áreas, los perjuicios al suelo, la tala masiva de árboles que llevan al deterioro del medio ambiente y la afectación de la salud. (Ostau, 2012, p. 92)

\subsubsection{2 ¿Para qué sirve la Planificación Ambiental? Utilidad}

La planificación ambiental sirve para manejar y aprovechar los recursos naturales renovables sin afectar el equilibrio ecológico (ambiental), ni alterar los ecosistemas.

Teniendo en cuenta lo anterior, sobre el tema de investigación y a manera de reflexión frente a las causas de lograr la evolución empresarial e industrial sin afectar el equilibrio ecológico, surgen unos interrogantes: Falta de conciencia en el tema ambiental?, faltará darle un valor económico a nuestros recursos naturales?, ayudará el endurecimiento de las leyes ambientales?, o se refleja la inexistencia de un sistema de planificación ambiental nacional?; claro, todo es trascendental, pero debemos enfocar nuestros actos y actuaciones en que el primer objeto de conservación es el hombre, y que el problema es actual, no un problema de futuro.

Debemos trabajar para nosotros mismos "la valoración humana" y dejar en segundo plano las generaciones futuras, es pensar que no queremos continuar viviendo dentro de un ambiente contaminado y que la calidad de vida cada día se agota; sellando la idea en afirmar que el ser humano es el bien ecológico $\mathrm{N}^{\circ}$ 1; en este sentido, me permito definir el desarrollo sostenible moderno - DSM, así: 
Son las actividades que satisfacen las necesidades de las generaciones presentes, respetando el límite del equilibrio ecológico previa planificación ambiental fijada por el Estado, enfocado al respeto de la vida humana presente, como bien ecológico esencial.

Seguido, connotar el concepto de desarrollo sostenible inmerso en el Informe de la Comisión Mundial sobre el Medio Ambiente y el Desarrollo (Brundtland):

El concepto de desarrollo sostenible ha buscado superar una perspectiva puramente conservacionista en la protección del medio ambiente, al intentar armonizar el derecho al desarrollo -indispensable para la satisfacción de las necesidades humanas- con las restricciones derivadas de la protección al medio ambiente. El desarrollo sostenible debe permitir elevar la calidad de vida de las personas y el bienestar social pero sin sobrepasar la capacidad de carga de los ecosistemas que sirven de base biológica y material a la actividad productiva. (ONU, 1987, p. 46)

Por su parte la legislación nacional Colombiana, mediante la ley 99 de 1993, puntualmente en su artículo $3^{\circ}$, precisó que:

Se entiende por desarrollo sostenible el que conduzca al crecimiento económico, a la elevación de la calidad de la vida y al bienestar social, sin agotar la base de recursos naturales renovables en que se sustenta, ni deteriorar el medio ambiente o el derecho de las generaciones futuras a utilizarlo para la satisfacción de sus propias necesidades. (Colombia, Sentencia, 1994)

La solidaridad entre generaciones humanas definidas por la doctrina y la jurisprudencia, viene siendo una motivación para la conservación y preservación de los recursos naturales renovables; al respecto, se propone renovar este concepto, con el entorno vital del hombre "su vida actual" (desarrollo sostenible moderno). Indispensable pensar en el ser humano del presente; en su defecto, sería letra muerta cualquier beneficio de la planificación ambiental.

\subsubsection{3 ¿Qué busca la Planificación Ambiental? Finalidad}

En este orden de ideas, realizado el diagnóstico y evidenciado que falta el marco o fundamento legal, que incide en la deficiencia del deterioro de los recursos naturales, frente a la ausencia de la "Planificación Ambiental" por parte de las autoridades públicas, y en busca de dar un gran salto para poder proponer una posible solución jurídica enfocado a que las entidades se 
vinculen de forma directa a planificar ambientalmente con la finalidad de garantizar el desarrollo sostenible moderno, su conservación, restauración o sustitución, minimizar los impactos ambientales, prevenir, controlar y disminuir los factores de deterioro ambiental, las afectaciones e infracciones ambientales, adoptar medidas eficaces para impedir la degradación del ambiente la recuperación de las áreas intervenidas, adquirir predios para destinarlos a la conservación, imponer sanciones, y exigir la reparación de los daños ambientales.

De otra parte, la ley 1437 de 2011 por la cual se expide el Código de Procedimiento Administrativo y de lo Contencioso Administrativo - CPACA (Entro en vigencia a partir del año 2012, en determinados distritos judiciales), consagró la protección del ambiente como un derecho e interés colectivo, y fue en su artículo 144, que precisó:

Cualquier persona puede demandar la protección de los derechos e intereses colectivos para lo cual podrá pedir que se adopten las medidas necesarias con el fin de evitar el daño contingente, hacer cesar el peligro, la amenaza, la vulneración o agravio sobre los mismos, o restituir las cosas a su Estado anterior cuando fuere posible. Cuando la vulneración de los derechos e intereses colectivos provenga de la actividad de una entidad pública, podrá demandarse su protección.

\subsubsection{Reseña Legislativa sobre temas similares}

De la revisión normativa en Colombia, se observa que han existido varios proyectos de ley radicados sobre la planificación ambiental dentro de la responsabilidad social ambiental empresarial, los cuales no han logrado convertirse en norma vigente, es decir se han archivado por diferentes causas dentro del Congreso de la República, así: Proyecto de ley № 153 de 2006, proyecto de ley $\mathrm{N}^{\mathrm{o}} 031$ de 2007, proyectos de ley No 058 de 2009 y No 070 de 2010.

Ahora bien, es pertinente enunciar que los proyectos de ley 153 de 2006, 031 de 2007, 058 de 2009 y 070 de 2010, fueron versiones muy similares radicadas por el movimiento político independiente de renovación absoluta - MIRA. El proyecto 031 de 2007 estuvo vigente por dos legislaturas, ya que se le dio trámite en Senado y Cámara de representantes. 


\subsubsection{Proyecto de ley $N^{\circ} 153$ de 2006}

En este sentido, el día 24 del mes de octubre del año 2006 se radicó en la plenaria del Senado el proyecto de ley $\mathrm{N}^{\circ} 153$ titulado "por la cual se reglamenta la responsabilidad social de las empresas, y se dictan otras disposiciones". Por la materia de qué trataba el mencionado proyecto de ley se asignó por competencia a la comisión tercera Constitucional permanente y se envió copia del mismo a la imprenta nacional con el fin de que fuera publicado en la gaceta del congreso y posteriormente dentro de su trámite, el proyecto de ley fue archivado por votación unánime el 24 de abril de 2007.

Importante enunciar que dentro del articulado propuesto se encontraba la obligación para las empresas de realizar una planificación ambiental, y era la obligación de preparar y publicar un informe anual donde se especificaran los impactos significativos de índole medioambiental, social, económica o financiero y una valoración de los impactos en materia ambiental programada para el año inmediatamente siguiente. Así mismo, se fijaba la obligación de las empresas de tener en cuenta en el giro de sus negocios una valoración del impacto ambiental, social, económico y financiero en cada una de sus actividades.

Seguido, otorgaba facultades al Gobierno para que expidiera un reglamento para la puesta en marcha de un Consejo de responsabilidad social empresarial que profiriera normas y evaluará el estado actual de la responsabilidad empresarial en Colombia; y de igual manera, se fijaba la carga para las empresas y los directores de las mismas quienes podrán ser sancionados por el consejo de responsabilidad social empresarial, según la gravedad de la falta, entre otros preceptos contenidos en este proyecto.

El espíritu y esencia del presente proyecto de ley muy bien planteados, con ligeras dudas en su alcance y ambicioso su autor en abordar la planificación ambiental, concatenado a lo social, lo económico o financiero; se resalta la importancia en el sentido de que figuraba como obligación la valoración de los impactos ambientales en cada una de las actividades empresariales; y es aquí donde se encuentra la armonía Constitucional con la planificación en el manejo y aprovechamiento de los recursos naturales renovables y la obligación pública y privada al respecto. 
Tiene su motivación el presente proyecto de ley en ser una regulación sobre la responsabilidad social de las empresas, para desarrollar la función social de la propiedad, la primacía del interés general sobre el particular y la responsabilidad empresarial enfocado a la preservación de un ambiente sano, prevista en la Carta Política de 1991 (artículos 58, 333 y 334).

\subsubsection{Proyecto de ley $\mathrm{N}^{\circ} 031$ de 2007}

Al continuar con el análisis del tema, nos encontramos con el proyecto de ley 031 de 2007 radicado en la secretaria general del Senado de la República el día 24 de julio de 2007 titulado "por la cual se definen normas sobre la responsabilidad social y medioambiental de las empresas y se dictan otras disposiciones". El Senado de la República cumplidos los requisitos legales de publicación y anuncio de esta iniciativa, aprobó el proyecto de ley en primer debate el 04 de diciembre de 2007 y en plenaria en segundo debate el 28 de mayo del 2008. Luego de ser aprobada por el Senado pasó a aprobatoria en la Cámara de representantes bajo el número P.L. 326 de 2008 y por lo dispuesto en la ley $5^{\text {a }}$ de 1992 en su artículo 157, el proyecto fue archivado el 14 de octubre de 2008 (Comisión quinta).

El presente proyecto de ley tenía por objeto establecer un conjunto de lineamientos que promovían la planificación ambiental, la responsabilidad social empresarial - RSE con comportamientos y actividades voluntarias, socialmente responsables, por parte de las factorías a partir del diseño, desarrollo e inicio de políticas, planes, programas, proyectos y operaciones, enfocados al logro en el campo social y ambiental, fundados en la prevención y reparación de los daños ambientales.

Dentro de los argumentos de la comisión frente al proyecto de ley, se rindió ponencia negativa para primer debate en Cámara de representantes y en consecuencia se presentó la proposición de archivarse el proyecto de ley $\mathrm{N}^{\circ} 326$ de 2008, motivado en que se desconfigura la filosofía al establecer por un lado, la obligatoriedad de rendir informes anuales de responsabilidad social de las empresas, la cual no se no se enmarcaría dentro de la naturaleza voluntaria de su concepto. Por otro lado, la obligación de consultar a los socios, por parte de las empresas en las decisiones ambientales (planificación), se afirmó que rompe el esquema de funcionamiento de las sociedades. 
$\mathrm{Al}$ respecto encontramos parcialmente fundado los motivos del archivo del proyecto de ley, pero de otra parte, estamos en desacuerdo al afirmar que la naturaleza de la responsabilidad social empresarial debe ser voluntaria, y que no se construye a partir de reglamentaciones, que se cimenta a partir de convencimientos éticos y beneficios tangibles; se afirmó que la RSE se basa en el comportamiento ético de las organizaciones, por lo que no es dable a la ley intervenir; es en sentido estricto nuestra oposición, ya que este precepto es subjetivo, no tiene asidero ni reglamentación legal, y es una oportunidad de darle piso jurídico para convertir la responsabilidad social ambiental como una obligación de planificación ambiental empresarial.

Se recomienda no dejar el tema a la libre voluntad empresarial, ya que los recursos naturales renovables no pueden negociarse, estamos hablando de la vida como derecho fundamental, y si es legislar para que los empresarios tengan beneficios tangibles como reciprocidad y dejar un rango de acción para la creatividad y el carácter innovador de las empresas en beneficio ambiental, enfocado al equilibrio entre las expectativas económicas empresarial y su impacto social y ambiental, en el marco de la planificación ambiental enfocada al desarrollo sostenible moderno.

\subsubsection{Proyecto de ley $\mathrm{N}^{\circ} 058$ de 2009}

En coherencia con el tema, nos referimos a un tercer proyecto de ley denominado "por la cual se definen normas sobre la responsabilidad social empresarial, la protección infantil y se dictan otras disposiciones", el cual recibió informe de ponencia negativa para primer debate en la comisión séptima Constitucional permanente del Senado de la República de Colombia y seguido, se ordenó el archivo del trámite legislativo.

El objeto del proyecto de ley en mención, era la promoción de comportamientos voluntarios, socialmente responsables, por parte de las empresas, a partir del diseño, desarrollo y puesta en servicio de políticas, programas y proyectos en busca del logro de objetivos sociales,

focalizando en aspectos como la protección de la niñez, la erradicación del trabajo infantil, la erradicación de la pobreza, el respeto de los derechos humanos y los comportamiento responsables ambientales basados en la prevención y la reparación de los daños ambientales, dentro de la planificación ambiental. 
Además, se fijaba que las empresas tendrían incentivos, entre los cuales, se otorgarían puntajes adicionales en licitaciones públicas, facilidades de acceso a créditos superiores a determinado monto, acceso a programas de fomento micro y pequeñas empresas, fomento de innovación tecnológica. Así mismo, se fijaba como obligación para cada empresa de publicar un informe anual especificando cualquier impacto significativo de índole medio ambiental (planificación), social, económico o financiero de sus actividades durante el año que termina y una valoración de los impactos significativos para el año inmediatamente siguiente, entre otras.

El proyecto tuvo su análisis y se emitió ponencia negativa con argumentos que no se comparten, como se manifestó anteriormente, entre ellos: se afirma que el marco jurídico, político y económico en el que se construye la lógica voluntaria del cumplimiento de las obligaciones de las empresas, se contrapone con la lógica normativa, imperativa, coercitiva y con efectos vinculantes de los derechos que poseen; al respecto reiterar que todas las leyes se emiten porque existen un vacío legal. En el derecho natural no existía legislación vinculante, todo era voluntario y a hoy, después de tantos soles y lunas, existen temas como la planificación en el manejo y aprovechamiento de los recursos naturales como obligación Estatal que amerita ser regulada con pautas obligatorias a favor del ambiente.

Dejando a un lado el tema de investigación en las presentes líneas, se refuta la afirmación dentro del trámite legislativo en mención que la responsabilidad social ambiental es una herramienta publicitaria, es una estrategia de posicionamiento de marca y de mercado, de fidelización de clientes, de mejoramiento de la imagen corporativa, y es aquí, donde amerita reglamentarse este tema; que no brille la discrecionalidad con la presentación de informes periódicos en la materia y que los sellos verdes o certificados socialmente responsables, más que añadir un "plus", debe ser el resultado del cumplimiento normativo vigente y de la garantía de proteger y conservar los recursos naturales renovables y de producir productos verdes o elaborados con técnicas sostenibles y su respectiva comercialización (mercados verde).

Se puntualiza en el informe de ponencia negativo de la comisión séptima Constitucional permanente, frente al proyecto de ley $N^{\circ} 058$ de 2009, que:

En gracia de discusión, aun aceptando posibles efectos positivos a partir de la creación del consejo de responsabilidad social empresarial y el reconocimiento a las empresas 
"Socialmente Responsables", considero que lo primero, es finalmente potestativo del Ejecutivo y lo segundo, reviste más un carácter publicitario dirigido al mercado, con lo cual no se encuentra la necesidad de desarrollo por la vía legislativa, es decir, a mi juicio el proyecto de ley no cumple claramente con el principio de utilidad normativa, toda vez que el cumplimiento de su objeto depende finalmente de la voluntad del Gobierno y de las empresas a las que va dirigido, y bien pueden hacerlo sin que medie norma ad hoc.

Al respecto, se comparte la precedente apreciación, las leyes deben cumplir con unos fines generales y no es viable dar trámite a una ley donde se va a dejar a la libertad su cumplimiento, sería una ley decorativa; por ende se recomienda que el alcance de la planificación ambiental empresarial sea vinculante y de obligatorio cumplimiento.

\subsubsection{Proyecto de ley $N^{\circ} 070$ de 2009}

El día 4 de agosto del año 2010 se radicó el proyecto de ley $\mathrm{N}^{\circ}$ 70, titulado "por la cual se definen normas sobre la responsabilidad social empresarial, la protección infantil y se dictan otras disposiciones", por competencia fue repartido y radicado el 09 de agosto de 2010 a la comisión séptima Constitucional permanente del Senado de la República, posterior a su trámite, el proyecto de ley fue retirado por solicitud de su autor el 15 de junio de 2011.

El texto del proyecto afirmaba que se buscaba la promoción de comportamientos voluntarios, socialmente responsables, por parte de las factorías basados en la prevención y la reparación de los daños ambientales; incluyó determinados incentivos para las empresas que voluntariamente se vincularan con la responsabilidad social ambiental; de igual manera, precisaba la opción de que las grandes empresas podrán apadrinar a las micro y pequeñas empresas, con el fin de acompañarlas durante el proceso de incorporación de la responsabilidad social empresarial, se conformaba el consejo de responsabilidad social empresarial y se estipulaba que las empresas deberán tener en cuenta una valoración del impacto ambiental en cada una de sus actividades dentro de la planificación ambiental.

Además se puso de presente dentro del proyecto de ley, la facultad otorgada al gobierno nacional para promover entre las empresas que se acogieran de manera voluntaria a la RSA para obtener la certificación socialmente responsable, que sería un medio de promoción, difusión y calidad sobre la gestión en la materia de cada empresa. 
$\mathrm{Al}$ respecto, se observa que este proyecto de ley fue muy similar a los enunciados con anterioridad; y cobra sentido al visualizar los informes frente al proyecto de ley por parte de los Ministros de Ambiente y de Hacienda allegados a la comisión séptima Constitucional del Senado de la República, donde marcaron sus opiniones sobre el tema de la responsabilidad social empresarial, no estando de acuerdo con el contenido del proyecto de ley en mención; observándose un desinterés por parte del gobierno nacional de aprobar y apoyar la presente iniciativa legislativa que lleva implícita parte de la planificación ambiental.

De todo lo anteriormente expuesto se desprende con mediana claridad que los cuatro proyectos de ley radicados tiene un común denominador que es la responsabilidad social ambiental empresarial conllevando a la planificación ambiental, pero cada uno tuvo temas diversos; en este sentido, el estudio les correspondió a comisiones diferentes y en un punto intermedio todas concibieron en afirmar que la responsabilidad social empresarial debe ser voluntaria, por lo que hacerla obligatoria mediante una ley es ir en contra de su propia esencia, precepto subjetivo de los ponentes no compartido en esta investigación.

\begin{tabular}{|c|l|c|c|}
\hline $\begin{array}{c}\text { Número del } \\
\text { Proyecto ley }\end{array}$ & \multicolumn{1}{|c|}{ Tema } & $\begin{array}{c}\text { Comisión } \\
\text { Constitucional }\end{array}$ & Estado \\
\hline PL 153 de 2006 & $\begin{array}{l}\text { Responsabilidad social empresarial } \\
\text { Comisión 3 }\end{array}$ & Archivado \\
\hline PL 031 de 2007 & $\begin{array}{l}\text { Responsabilidad social y medioambiental } \\
\text { de las empresas }\end{array}$ & Comisión 5 & Archivado \\
\hline PL 058 de 2009 & $\begin{array}{l}\text { Responsabilidad social empresarial y la } \\
\text { protección infantil }\end{array}$ & Comisión 7 & Archivado \\
\hline PL 070 de 2010 & $\begin{array}{l}\text { Responsabilidad social empresarial y la } \\
\text { protección infantil }\end{array}$ & Comisión 7 & Archivado \\
\hline
\end{tabular}

La suerte de los proyectos de ley ya fueron enunciadas, todos fueron archivados. Los dos primeros por inconveniencias, el tercero por tránsito en su legislatura y el último retirado por su autor. De los cuatro, el único que alcanzó a recibir un guiño por parte de los legisladores fue el PL 031 de 2007, el cual llegó a ser aprobado por la plenaria del Senado, pero se cayó tras su debate en comisión realizada en la Cámara de Representantes. Esto significa, que a pesar de los intentos de los autores para regular la obligatoriedad de la responsabilidad social ambiental 
empresarial como desarrollo de la planificación ambiental, tal iniciativa no logró el consenso de los distintos actores involucrados, para alcanzar su aprobación por parte del sector privado y del Gobierno nacional.

De todo lo anteriormente expuesto y continuando con la dirección de la investigación, se desprende con claridad que las diferentes funciones Constitucionales y legales enunciadas en los capítulos precedentes y de los proyectos de ley analizados, queda ratificado que dentro del ordenamiento jurídico vigente, no existe norma que regule la planificación ambiental, donde se precise unas pautas serias y vinculantes para la Nación, las autoridades públicas y privadas; que sea la oportunidad de pensar con criterio ambientalista, proyectados en actuar de forma sostenible a nivel local, regional y nacional para asegurar nuestro presente con calidad de vida sostenible. En este sentido, es nuestro deber de plantear una solución al problema de la presente investigación.

\subsection{Contexto Externo sobre la Planificación Ambiental}

Recientemente se registró en los medios de comunicación que por la influencia humana hay cambios en la atmosfera, en océanos y en la reducción de la nieve y el hielo, (EFE, Nueva York, 2014), así:

Alerta informe de la ONU. El aumento en la emisión de gases de efecto invernadero desataría un "irreversible y generalizado impacto" en las próximas décadas, si no se acuerdan políticas para evitarlo, según el borrador de un informe de la ONU conocido ayer. El informe es preparado por el Panel Intergubernamental sobre el Cambio Climático de la ONU, la mayor red científica dedicada al estudio de este fenómeno. Las emisiones de gases de efectos invernaderos crecieron a un nivel de 1,3\% de cada año desde 1970 al 2000, pero a partir de entonces el aumento anual fue del $2.2 \%$.

Realizando una breve revisión en el contexto internacional encontramos una realidad no desconocida, un problema ambiental actual de mundo, la falta de planificación es evidente, diagnosticado en los diferentes informes de evaluación e informes especiales, entre ellos los publicados por la (ONU, 2012), donde se ha precisado lo siguiente:

El mundo de hoy tiene 7 mil millones de personas, para el año 2050, habrá 9 mil millones. Una de cada cinco personas, es decir 1.400 millones, actualmente vive con 1,25 dólares 
diarios o menos. Mil quinientos millones de personas no tienen acceso a la electricidad. Dos y medio millones de personas no tienen un cuarto de baño. Casi 1.000 millones de personas pasan hambre todos los días. Las emisiones de gases de efecto invernadero continúan aumentando, y más de un tercio de todas las especies conocidas podrían extinguirse si el cambio climático continúa sin control. Actualmente 25 países prácticamente carecen de cubierta forestal, en otros 29 países solo queda menos del 10\% de la cubierta forestal y el $20 \%$ de todos los arrecifes de coral ha desaparecido, perturbando gravemente la pesca y exponiendo a las zonas costeras, las islas y las personas que dependen de ellos a mayor erosión e inundaciones.

Precedente al tema y al detectar el problema del cambio climático mundial, la Organización meteorológica mundial (OMM) y el Programa de las naciones unidas para el medio ambiente (PNUMA) crearon el Grupo intergubernamental de expertos sobre el cambio climático - IPCC. (Intergovernmental Panel on Climate Change, 1988)

En esta misma línea y en busca de una solución a la problemática global y como un compromiso previo, se llevó a cabo la Conferencia de las naciones unidas sobre el desarrollo sostenible, conocida ésta conferencia como Rio +20 , en la cual como resultado se redactó un documento final denominado "El Futuro que Queremos" con un total de 283 ítems con exhortaciones ambientales y bajo un contexto de la planificación ambiental; dentro de los cuales se precisaron:

Nosotros, los Jefes de Estado y de Gobierno y los representantes de alto nivel, habiéndonos reunido en Río de Janeiro (Brasil) del 20 al 22 de junio de 2012, con la plena participación de la sociedad civil, renovamos nuestro compromiso en favor del desarrollo sostenible y de la promoción de un futuro sostenible desde el punto de vista económico, social y ambiental para nuestro planeta y para las generaciones presentes y futuras.

Reconocemos que las personas son el elemento central del desarrollo sostenible y, a este respecto, nos esforzamos por lograr un mundo que sea justo, equitativo e inclusivo, y nos comprometemos a trabajar juntos para promover el crecimiento económico sostenido e inclusivo, el desarrollo social y la protección del medio ambiente, lo cual redundará en beneficio de todos. Reafirmamos la necesidad de fortalecer la gobernanza ambiental internacional en el contexto del marco institucional para el desarrollo sostenible a fin de 
promover la integración equilibrada de las dimensiones económica, social y ambiental del desarrollo sostenible, así como la coordinación en el sistema de las Naciones Unidas.

Nos comprometemos a fortalecer la función del Programa de las Naciones Unidas para el Medio Ambiente como principal autoridad ambiental mundial que establece la agenda mundial en favor del medio ambiente, promueve la ejecución coherente de los aspectos ambientales del desarrollo sostenible en el sistema de las Naciones Unidas y actúa como defensor autorizado del medio ambiente mundial.

Acogemos con beneplácito los compromisos asumidos voluntariamente en la Conferencia de las Naciones Unidas sobre el Desarrollo Sostenible y a lo largo de 2012 por todos los interesados y sus redes para poner en práctica políticas, planes, programas, medidas y proyectos concretos encaminados a promover el desarrollo sostenible y la erradicación de la pobreza. Invitamos al Secretario General a que recopile esos compromisos y facilite el acceso a otros registros similares en un registro en Internet. La información de ese registro relativa a los compromisos debe ser plenamente transparente y accesible al público y actualizarse periódicamente.

En el documento referido se abordaron lineamientos y se fijaron compromisos voluntarios para los países del mundo, entre ellos temas como la erradicación de la pobreza, seguridad alimentaria y agricultura sostenible, agua y saneamiento, energías limpias, turismo sostenibles, transporte sostenibles, ciudades y asentamientos humanos sostenibles, salud y población, promoción del empleo, reducción del riesgo de desastres, planificación ambiental, cambio climático, bosques, diversidad biológica, desertificación, degradación de la tierra y sequía, montañas, productos químicos, consumos y desechos, producción sostenible y minería; lo anteriormente enunciado en armonía con el desarrollo sostenible como resultado de la planificación ambiental. No sobra afirmar que se fijaron retos voluntarios y no vinculante para las partes.

De otra parte, la Constitución de la Ciudad de Buenos Aires (Argentina), el capítulo en referencia al ambiente es el cuarto (IV), puntualmente los artículos del 26 al 30, entre ellos se ordena:

Redactar un Plan Urbano Ambiental y también hacer Códigos de Planeamiento Urbano y Medio Ambiente. La idea es reunir en un solo lugar todas las normas que tengan que ver con 
el ambiente humano...., protección de los recursos naturales, definiciones técnicas, herramientas de la política ambiental, junto con el manejo de los recursos urbanos (peligrosos o no peligrosos), la contaminación del agua y del aire, los ruidos y el ordenamiento de las fuentes de energía. La Constitución ordena establecer un proceso de ordenamiento ambiental participativo.... Pero también se indica qué, cosas cuidar cuando se haga ese ordenamiento ambiental. (Brailovsky, 1997, Pp. 140 y 141)

Se observa que las organizaciones mundiales y sus países vienen haciendo un esfuerzo de crear conciencia, emitir políticas, realizar acuerdos, tratados, cumbres, convenciones, y fue en este sentido que hace más de cuarenta años se realizó la declaración de la Conferencia de las naciones unidas sobre el medio humano, en Estocolmo - Suecia, como respuesta a la evidente necesidad de definir unos principios comunes que requerían los pueblos del mundo como guía para preservar y mejorar el medio humano, fundado en la planificación y ordenación de los recursos naturales.

La Agencia Europea de Medio Ambiente, es un organismo de la Unión Europea. Su labor es ofrecer información sólida e independiente sobre el medio ambiente. Es la fuente principal de información para los responsables del desarrollo, la aprobación, la ejecución y la evaluación de las políticas medioambientales, y también para el gran público. En la actualidad, la AEMA tiene 32 países miembros. (EEA, 2013)

De otra parte, la comunidad europea ha venido trabajado sobre temas de planificación ambiental en simbiosis con la responsabilidad ambiental y ha recomendado que "en los países que carecen de tales reglamentaciones, los esfuerzos se deberían centrar en la instauración del marco legislativo o reglamentario adecuado", presentado en el Libro Verde de la Unión Europea, en el cual se redactó lo siguiente:

Ser socialmente responsable no significa solamente cumplir plenamente las obligaciones jurídicas, sino también ir más allá de su cumplimiento invirtiendo «más» en el capital humano, el entorno y las relaciones con los interlocutores..... Incluyen, además, las prácticas respetuosas con el medio ambiente relacionadas con la gestión de los recursos naturales empleados en la producción. (Comisión de las Comunidades Europeas, 2001, pp. 8 у 9) 
Pues bien aterrizando este marco conceptual, al caso que nos ocupa, lo primero que debe reiterarse es que es un hecho cierto la obligación del Estado de planificar el manejo y aprovechamiento de los recursos naturales, seguido que en Colombia las autoridades públicas viene haciendo su labor frente al tema sin un norte definido y sin una ruta de ordenamiento ambiental. En un contexto universal, se observa igual tendencia, y un mundo cada vez más degradado por la ausencia de planificación ambiental, y las consecuencias se tipifican, así:

Las personas sumidas en la pobreza se ven afectadas de forma desproporcionada por el deterioro del medio ambiente y la falta de acceso a servicios energéticos limpios y asequibles. Estos problemas abarcan a todo el globo, ya que el cambio climático, la disminución de la diversidad biológica y el agotamiento de la capa de ozono no pueden ser resueltos por las naciones individualmente. Si la tendencia actual de crecimiento económico y de población continúan y sin nuevas tecnologías ni cambios drásticos sobre cómo se utilizan los recursos, nuestro planeta no podrá sostener la economía mundial. Para el PNUD el cambio climático no es sólo un problema ambiental crítico, sino también un serio desafio para el desarrollo de todos los países. La capacidad de las personas y las sociedades de gestionar los riesgos potenciales del cambio climático y de adaptarse y responder a estos, varía considerablemente en todo el mundo. (PNUD, 2014)

Por lo anterior y con los argumentos planteados, se recomienda para el mundo crear la

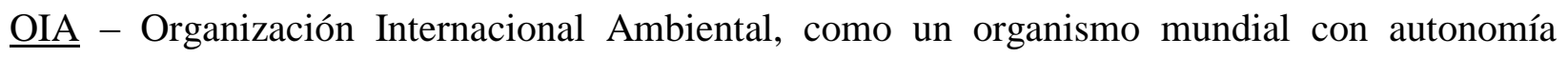
administrativa y financiera, con su propia reglamentación, enfocado a unificar las diferentes legislaciones inter-nacionales ambientales, realizar el seguimiento a los tratados, convenciones y compromisos de los países del mundo bajo pautas y alternativas para alinear los intereses individuales con el general, bajo un enfoque de planificación ambiental universal, y ser el protector de "La vida del planeta".

El Programa de las naciones unidas para el desarrollo - PNUD ayuda a los países a fortalecer sus capacidad para enfrentar los desafíos medioambientales a nivel mundial, nacional y de la comunidad, buscando y compartiendo las mejores prácticas y proporcionando una política de asesoría innovadora, relacionando a los socios mediante proyectos que ayuden a las personas en los países en vías de desarrollo a construir modos de vida sostenibles. (PNUD, 2014) 
Otros esfuerzos de programas y entidades internacionales con enfoque a favor del ambiente, son: El Banco mundial, el Programa de la ONU para el medio ambiente (PNUMA), el cual se estableció mediante la resolución 2997 (XXVII) de la asamblea general celebrada el 15 de diciembre de 1972, el Fondo para el medio ambiente mundial (FMAM) - Banco interamericano de desarrollo (BID), el mayor fondo a nivel mundial para proteger el medio ambiente, la Unión internacional para la conservación de la naturaleza (UICN), el Consenso de Monterrey (México, 2002) y la Declaración de Doha (Qatar, 2001) sobre la financiación para el desarrollo; todos con un enfoque para que los Estados integren la protección ambiental en sus estrategias de reducción de la pobreza y el desarrollo sostenible se traduzcan de manera plena y efectiva en resultados tangibles para la conservación y protección ambiental.

De igual manera, la división de legislación y convenciones ambientales - DELC (por sus siglas en inglés) tiene como tarea: la implementación del derecho y las políticas ambientales, liderando las siguientes funciones del PNUMA en:

Promover el desarrollo progresivo y la implementación del derecho ambiental como respuesta a los desafíos ambientales; en particular, apoyando a los Estados y a la Comunidad Internacional a fortalecer su capacidad para desarrollar e implementar marcos legales. (PNUMA, 2014)

Pero como tal, son solo programas y su fuerza no es vinculante para todos los países del mundo, como sí lo son los problemas ambientales que abarcan a todo el globo, y lo afirmó el PNUD, así "estos problemas ambientales no pueden ser resueltos por las naciones individualmente", de ahí la gran necesidad de la creación de la Organización Internacional Ambiental - $\underline{\text { OIA }}$, como una entidad mundial ambiental y no como un programa más de la simple voluntad de protección ambiental, el deber ser, es convertir las voluntades en norma de normas con aplicación y estándares internos de cumplimiento para cada uno de los países del mundo.

Se recomienda que la nueva reglamentación de la Organización Internacional Ambiental - $\underline{\text { OIA }}$ se fundamente en la "planificación ambiental" y enfocado a la "valoración humana", es saber que nuestra vida es la mayor riqueza ambiental sobre el planeta, y en el marco del concepto de desarrollo sostenible moderno; es darle un giro al pensamiento, ya no cuidar el ambiente para las generaciones del futuro, es pensar en un problema ambiental del presente, del hoy. 
Siendo una necesidad, debemos manifestarlo desde ya, que refiere de una solución tan oportuna e inaplazable, que obviamente no puede esperar el agotamiento finito de los recursos naturales renovables; visto lo anterior, es nuestro deber de plantear una propuesta para la solución al problema de la presente investigación, estructurada a continuación:

\subsection{Sistema de Planificación Ambiental Nacional - SISPAN}

En este orden de ideas, se avizoró la existencia de un soporte Constitucional ambiental fundado en un sinnúmero de axiomas y postulados que dan piso jurídico, reflejando su reglamentación ambiental, mediante leyes o decretos vigentes sin un norte, ni planificación ambiental definida.

Es así como nos permitiremos presentar la siguiente estructura de lo que a bien podría ser la propuesta de reglamentación para cumplir con la obligación contenida en el artículo 80 de la Constitución Política, que precisa "El Estado planificará el manejo y aprovechamiento de los recursos naturales, para garantizar su desarrollo sostenible".

Tomando como base lo anteriormente manifestado, presentaremos los cinco (5) componentes de la estructura propuesta para incorporar "La Planificación Ambiental" como un sistema de gestión gerencial, incorporada como una política pública; al respecto lo graficaremos cada ítem con una pregunta frente a los recursos naturales renovables y su posible respuesta, así:
A. Que tenemos? Elaboración de un diagnóstico de los recursos naturales renovables
B. Cuánto valen? Contabilidad ambiental
C. Como lo vamos a utilizar? Ordenamiento ambiental y minimizando los factores de deterioro
D. Con que lo vamos a recuperar? Políticas previas Estatales

E. Que vamos a entregar a cambio? La responsabilidad social ambiental - RSA

Precisamos en estructurar una planificación en el manejo y aprovechamiento de los recursos naturales renovables, entre ellos: la flora, el agua, la fauna, el aire, el suelo - territorio, y la fauna. Como insumos utilizaremos la legislación ambiental existente y vigente, en forma básica lo expuesto en el decreto 3570 de 2011 que le asignó funciones al Ministerio de Ambiente 
y Desarrollo Sostenible como rector de la gestión del ambiente y de los recursos naturales renovables, entre otros referentes; así:

\subsubsection{Que tenemos? Diagnóstico de los recursos naturales renovables}

Para poder dar respuesta a la pregunta de cuáles son los recursos naturales renovables que se tienen en Colombia y en qué cantidad y el estados o condiciones de los mismos; es acertado en afirmar que de la revisión normativa ambiental de la investigación, ninguna entidad tiene asignada la función de realizar un inventario físico de los recursos naturales renovables a nivel nacional, conexo al diagnóstico de sus condiciones; ya que al Ministerio de Ambiente le corresponde como ente rector organizar el inventario de la biodiversidad nacional, pero organizar es diferente a realizar o elaborar este inventario, siendo el punto de partida de la presente propuesta de reglamentación.

Si sabemos que tenemos, y el estado actual de los recursos naturales renovables, podemos realizar una planificación en el manejo y aprovechamiento de los recursos naturales renovables y así dar cumplimiento a lo dispuesto en el artículo 80 Constitucional.

En armonía frente al tema, de conformidad con lo determinado en el artículo $2^{\circ}$ del decreto 3570 de 2011, donde se fijaron las funciones del Ministerio de Ambiente y Desarrollo Sostenible, numerales 9 y 12, precisa que le corresponde:

9. Dirigir y coordinar el proceso de planificación y la ejecución armónica de las actividades en materia ambiental de las entidades integrantes del Sistema Nacional Ambiental (SINA). 12. Establecer el Sistema de Información Ambiental, organizar el inventario de la biodiversidad y de los recursos genéticos nacionales; y administrar el Fondo Nacional Ambiental (Fonam).

En este orden de ideas, se recomienda que el Ministerio de Ambiente y Desarrollo Sostenible profiera un decreto reglamentario con la firma del Presidente de la República, por el cual exijan a las diferentes autoridades ambientales locales, regionales y nacionales la obligatoriedad de realizar un inventario o diagnóstico físico ambiental; para determinar los recursos naturales renovables existentes, su cantidad y condiciones de forma individual (aire, agua, flora, fauna, etc.) y una aproximación de su disponibilidad para el aprovechamiento sin afectar el equilibrio ecológico y la subsistencia de los mismos. 
En este sentido, se puede logar la organización del inventario de la biodiversidad nacional, y es el Ministerio de Ambiente y Desarrollo Sostenible - MADS, quien consolidará toda la información y con base en la misma, realizará una verdadera planificación en el manejo y aprovechamiento de los recursos naturales renovables y expedirá la reglamentación que amerite al respecto, soportada en los principios ambientales, entre ellos: principio de precaución, principio el que contamina paga, armonía regional, gradación normativa y rigor subsidiario (ley 99 de 1993, art 63).

Si la reglamentación propuesta existiese en Colombia y se cumpliera con la obligación por parte del Estado de realizar la planificación ambiental, se hubiese podido minimizar las consecuencias del fenómeno del "Niño" que se vivió en Colombia (Julio a Septiembre de 2014), caso especial en los departamentos de la Guajira, Santander y los Llanos orientales, donde la sequía y/o escasez de agua fue el día a día con consecuencias de pérdida de vidas humanas, perdida de cultivos, afectaciones en la ganadería, entre otras afectaciones ambientales y sociales; situación reiterada en la ciudad de Santa marta, donde el preciado líquido no está llegando a las familias como consecuencia de la sequía en el lugar, convirtiéndose lo anterior, en una problemática pública, ambiental y social de la ciudad (Marzo de 2015).

Frente a la presente situación crítica ambiental, se profirió directriz por parte del gobierno nacional de realizar inversiones económicas para minimizar la problemática y proponer la realización de estudios de las aguas subterráneas (hidrogeológicos), para así poder extraerlas y llevar una solución transitoria de oferta hídrica a los habitantes de los departamentos y municipios afectados; quedando evidenciado una falta de planificación ambiental, una omisión de las obligaciones Constitucionales por parte de las entidades Estatales; queda demostrado una responsabilidad extracontractual del Estado quien debe responder patrimonialmente por los daños antijurídicos imputables por la omisión de las funciones como autoridades públicas frente al tema; pudiéndose prever esta situaciones de presente y el futuro.

En fin, una tercera posición, recientemente acogida en sede jurisprudencial, sostiene que la responsabilidad por las afectaciones del ambiente constituye una responsabilidad especial o singular que, en su condición de tal, no debe remitirse ni subsumirse en otro sistema específico... En concreto, el artículo16 de la Ley 23 de 1973, incorpora una disposición que, a las claras, edifica un sistema especial o singular de responsabilidad por afectaciones al 
ambiente, al preceptuar que "El Estado será civilmente responsable por los daños ocasionado al hombre o a los recursos naturales de propiedad privada como consecuencia de acciones que generan contaminación o detrimento del ambiente. Los particulares lo serán por las mismas razones y por el daño o uso inadecuado de los recursos naturales de propiedad del Estado”. (Rojas, 2012, Pp. 40 y 41)

Ahora bien, siguiendo nuestra línea argumentativa sobre la falta de planificación ambiental por parte del Estado, son las evidencias plasmadas en los recientes reportes en los medios de comunicación, televisivos, radiales y documentales, así: Acuerdo por la sequía pide la Federación Colombiana de municipios (Fedemunicipios).

Un gran pacto por el medio ambiente para prevenir los efectos del cambio climático a futuro es el que le pediría la Federación Colombiana de municipios al Presidente de la República de Colombia a propósito de la fuerte sequía que azota actualmente al país, la sequía es importante mirar la con inmediatez, para ver qué planes podemos hacer de mitigación, pero hay que hacer un gran acuerdo nacional por la prevención, porque esto siempre pasa y siempre estamos con urgencias atacando los efectos climáticos como la sequía. Se debe analizar una estrategia de reforestación de todo el país, para no padecer la escasez de agua. "Nos va a dar muy duro este fenómeno del niño porque recién está comenzando y ya tenemos un problema nacional”. (ADN, 2014)

Así lo manifestó el Presidente de ésta organización que agrupa a todos los municipios de Santander, no teniendo presentación que en pleno año 2014 y 2015 se esté hablando de un acuerdo nacional para la prevención con el Presidente de la República y se éste reconociendo que las afectaciones ambientales son reiterativas como consecuencia del cambio climático; lo que asombra es que no se solicite por parte de los representantes de los entes territoriales el cumplimiento del mandato Constitucional en materia de planificación ambiental.

Otro anuncio publicado en un periódico nacional donde se registra la falta de planificación ambiental como responsabilidad social ambiental por parte del Estado, es el siguiente:

Suspenden trámites de concesiones de agua en 74 municipios de Santander. Teniendo en cuenta que tanto los ríos como las quebradas de Santander presentan una gran disminución de sus caudales, la corporación autónoma regional de Santander, CAS, suspendido 
temporalmente el trámite de concesión de aguas en los 74 municipios de su territorio. La razón: controlar de esta forma el desabastecimiento del preciado líquido entre las comunidades. (Vanguardia Liberal, 2014)

En el presente caso, si se hubiese realizado la totalidad de ordenación de las cuencas hidrográficas en el departamento de Santander, aunado a los estudios hidrogeológicos e hídricos para determinar el caudal y cantidades aproximadas de las fuentes hídricas y con base en una modelación se podría prever estas situaciones consecuencias del calentamiento global y así se tendría una real planificación ambiental por parte del Estado en cumplimiento de su obligación Constitucional.

Un fuerte llamado les hizo la procuraduría a los alcaldes de 452 municipios de Colombia, por no reportar ni actualizar sus planes a la unidad nacional de gestión del riesgo; sobre todo, en un momento tan crítico como el de la inminente llegada del fenómeno del niño. En el marco de la cumbre nacional de alcaldes realizada en Bucaramanga, se cuestionó seriamente a los mandatarios, "por no haber adoptado medidas concretas ante la grave situación que vive el país tras las pocas lluvias y las altas temperaturas, ocasionadas por el citado fenómeno natural." Resulta inadmisible que sus autoridades municipales no hayan actuado con la diligencia y la prontitud que el clima lo amerita. (Vanguardia Liberal, 2014)

La anterior propuesta de realizar un inventario y/o diagnóstico nacional es para cada uno de los recursos naturales renovables (aire, fauna, flora, agua, suelo, etc.); para el caso concreto del recurso hídrico, se recomienda dar aplicación a las diferentes metodologías del cálculo del índice de escasez de agua y la estimación de caudales ambientales, la política nacional y lo incluido en el artículo $8^{\circ}$ del decreto 1640 de agosto 02 de 2012, el cual obliga, a:

Las autoridades ambientales competentes elaborarán las evaluaciones Regionales del Agua, que comprenden el análisis integrado de la oferta, demanda, calidad y análisis de los riesgos asociados al recurso hídrico en su jurisdicción para la zonificación hidrográfica de la autoridad ambiental, teniendo como base las subzonas hidrográficas.

Cerrando con la evidente necesidad de realizar un diagnóstico e inventario físico de los recursos naturales renovables como fase previa de la planificación y fijación de políticas 
ambientales Nacional, se participa lo dispuesto por la Corte Constitucional en la sentencia C-423 del 29 de septiembre de 1994, así:

La protección del ambiente, es asunto que le compete en primer lugar al Estado, aunque para ello debe contar siempre con la participación ciudadana a través del cumplimiento de sus deberes Constitucionales, en especial, de los consagrados en el artículo 80. superior: "proteger las riquezas culturales y naturales de la Nación", así como el numeral 8o. del artículo 95, que prescribe entre los deberes de la persona y del ciudadano el de "velar por la conservación de un ambiente sano".

Ahora bien, el cumplimiento del deber de procurar la protección del ambiente se logra, principalmente, a través de dos vías: la planificación y fijación de políticas Estatales, por una parte; y, por la otra, la consagración de acciones judiciales encaminadas a la preservación del ambiente y a la sanción penal, civil o administrativa cuando se atente contra él, las cuales pueden ser impetradas por el mismo Estado o por cualquier ciudadano.

(Colombia, Sentencia, 1994)

Para tal efecto, se recomienda que el gobierno nacional se apoye técnica y económicamente con fuentes de cooperación internacional, entre ellas: USAID, Banco Mundial, WWF, Embajada de los países bajos y el Programa de las naciones unidas para el desarrollo (PNUD) quien “está a la vanguardia en la prestación de ayuda a los países para la gestión de su respuesta al cambio climático en varios sectores, incluidas la lucha contra la pobreza, la reducción de los riesgos de desastre, la eficiencia energética y la ordenación de los recursos naturales"; encontrando diferentes componentes de apoyo a la planificación ambiental, con el fin de mitigar los daños irreversibles en los recursos naturales renovables del país.

\subsubsection{Cuánto valen? Contabilidad ambiental}

En este aspecto debemos enunciar sine qua non el concepto de la contabilidad ambiental, las externalidades y los instrumentos económicos ambientales.

. Cuánto vale económicamente un árbol? Quien asume éste valor al momento de talar un árbol? será el propietario del predio donde ésta ubicado el árbol o el Estado por afirmarse que es el propietario de los recursos naturales y que el árbol presta un servicio ambiental de interés general. Quien es el propietario de la flora o debe pagar el valor del árbol la persona que recibe 
una contraprestación por la madera? O si el árbol se derriba para hacer un proyecto de viviendas, quien compre el apartamento asumirá el valor del árbol a prorrata (cuota parte) o los propietarios del proyecto que se beneficiaran económicamente? Y la tasa por su utilización (tala) está reglamentada y se hace efectivo su cobro?

Es trascendental socializar que en la Gaceta Constitucional N ${ }^{\circ} 46$ de abril 15 de 1991, en el informe de ponencia del Medio Ambiente y los Recursos Naturales en desarrollo de la Asamblea Nacional Constituyente, quedo contemplado $N^{\circ}$ 5. Cuentas Nacionales, que:

Varios proyectos y propuestas sugieren establecer por Constitución la obligación que la contabilidad nacional incorpore el criterio de enriquecimiento o agotamiento de los recursos naturales. Si bien los ponentes concuerdan con la importancia de que se proceda de esta manera, consideran que se trata de una norma de carácter legal o reglamentario.

Respecto a la contabilidad ambiental, la contabilidad financiera y las cuentas nacionales, nos enmarcamos en la propuesta de implementar un sistema contable ambiental para Colombia en armonía con la planificación ambiental de acuerdo a los sostenido en el artículo $80 \mathrm{CP}$; en este orden de ideas, podemos afirmar según (Mantilla P. E., 2013, p. 19), que:

La contabilidad ambiental es el sistema que permite el reconocimiento, la organización, la valorización y el registro de las condiciones y los cambios en los recursos naturales y del ambiente, y hace posible articular indicadores de evaluación de sostenibilidad del ecosistema en el contexto del desarrollo, y vincular sistemas de información que faciliten el control de las acciones que afectan la condición de la naturaleza y el desarrollo nacional.

En consecuencia, queda por resolver la valorización ambiental en cifras monetarias, como alternativa eficiente en la comparación cruzada de los efectos de la actividad económica en la condición ambiental. No es esta una tarea fácil, pues el bienestar del hombre por la calidad de su entorno no corresponde a los beneficios directos derivados del usufructo de la naturaleza, ni exclusivamente a la disponibilidad y utilización del dinero para darle trato tanto a los bienes ambientales como los privados, en donde su valor se tasa en un mercado, en razón de que el valor de los recursos ambientales no corresponde a valores inducidos por la individualización o privatización de sus beneficios, sino al equilibrio de vida en el planeta." (p. 20) 
Un sistema contable integral. En virtud de las circunstancias que rodean el desarrollo de una nación y el papel que en este representan los recursos de la naturaleza como fuente de suministro de los elementos fundamentales de todo proceso productivo, es imprescindible contar con herramientas que faciliten el control y la evaluación del manejo ambiental, de los impactos provocados por acciones humanas o por la misma naturaleza, y del registro contable de los recursos y costos ambientales para que sean comparables periódicamente con los hechos económicos, con el fin de definir los avances hacia la sostenibilidad." (p. 13)

La contabilidad financiera y las cuentas nacionales son los instrumentos creados para la medición y evaluación del comportamiento económico, a partir de las cuales se define si los procesos son sostenibles o no. Un ejemplo claro lo constituye el hecho de que un árbol no debe ser valorado por su capacidad leñosa, maderable, o solo por sus frutos, sino por la recuperación atmosférica, la protección del suelo y por servir de hábitat a diferentes especies, -entre otros beneficios- resultado, en consecuencia, menor el valor de los bienes con el producidos. Entonces lo ideal es estructurar un subsistema de contabilidad ambiental, como elemento constitutivo de un sistema integral de contabilidad nacional, como unidad sistemática independiente en si operación, valoración y registro, interrelacionado con las cuentas nacionales y con la contabilidad o balance social, por medio de indicadores definidos y diseñados de manera objetiva, en cumplimiento de los propósitos de la evaluación, "el desarrollo sostenible”. (p. 14)

Importantes apreciaciones que se vislumbran en el libro de la medición de la sostenibilidad ambiental elaborado por la Universidad Cooperativa de Colombia - UCC (Sede Bucaramanga), y aún más allá, han propuesto un modelo o sistema de información de cuentas de control y balanza ambiental planteado entre otros profesionales por el Ing. Crisanto Vergel.

Es así como entramos a precisar la existencia de otras propuestas de valorización ambiental que se centran en el quehacer económico y que se han utilizado para definir el valor de escenarios de interés para determinadas naciones, como lo enseña (Azqueta, 1997) en los diferentes métodos, entre ellos: costos inducidos o evitados, el método del coste de viaje, método hedónico, método de valorización contingente.

Para determinar o establecer el valor de los recursos de la naturaleza en términos monetarios es quizás el tema más complejo dentro del análisis del desempeño de una economía, cuando se pretenden evaluar sus avances en el desarrollo con sostenibilidad. Si el 
dinamismo económico se mide por el flujo de dinero, todos sus efectos, sociales y ambientales, se deben comparar y evaluar con los mismos patrones; de lo contrario, las expresiones que resulten de los análisis serian subjetivas e incomparables, y carecerían de una importancia relativa para redireccionar la política de sostenibilidad. (Mantilla P. E., 2013, p. 19)

La valorización o determinación de costos ambientales envuelve el reconocimiento de las condiciones y características de los recursos naturales, porque de ello depende su valor relativo, en correlación con los beneficios y efectos sobre el ser humano, puesto que las cosas tienen precio en la medida en que reportan algún bien o servicio al hombre; y es en este orden de ideas, se recomienda aplicar la contabilidad ambiental y realizar la valoración de los recursos suelo, flora, fauna, aire, agua, paisaje, en fin la valoración de todos los recursos naturales renovables y sus ecosistemas integrales.

Y aunado a lo precedente, y de acuerdo a la norma de calidad ISO 14001 - 14001, la cual no tiene un carácter vinculante, se afirma que:

La auditoría ambiental se puede definir como el instrumento de gestión que comprende una evaluación sistemática, documentada, periódica y objetiva de la eficacia de la organización, del sistema de gestión y procedimientos destinados a la protección del medio ambiente, y tiene por objeto facilitar el control de las practicas que puedan tener efectos sobre el medio ambiente y evaluar sus adecuación a las políticas ambientales.” (ICONTEC NC ISO 14001 - 14009)

Es en este sentido, se puede definir que los instrumentos de regulación ambiental, son un mecanismo Estatal de intervención en la economía, buscando incidir en la estructura de precios y por lo tanto en la competitividad; pretendiendo modificar sus conductas negativas con el entorno, y las externalidades ambientales, así:

Las externalidades ambientales son sólo una clase particular de externalidades (o efectos externos). No son más importantes que cualquier otro tipo de externalidad económica pero no sería posible encontrar argumentos racionales para justificar que lo son menos. Si se desea adoptar decisiones más complejas y, por lo tanto, mejores, estas externalidades deberían ser debidamente cuantificadas e incorporadas en el marco de un análisis coste- 
beneficio de las decisiones públicas o privadas de la sociedad. (German Agency for Technical Cooperation, NU. CEPAL, 2008, p. 82)

Al revisar lo definido para las externalidades se debe diferenciar entre valoraciones sociales y valoraciones privadas, y son los efectos externos que se deben reflejar en los precios del mercado, precisaría que las externalidades negativas, son sinónimos de contaminación aunado a un valor económico cuantificable. Max-Neef señala:

En la contabilidad macroeconómica no se incluyen los servicios ambientales por la naturaleza, es decir, la absorción gratuita de contaminantes, su capacidad de proporcionar agua, energía, elementos y compuestos químicos, riqueza genética. Esas condiciones naturales de la producción permanecen invisibles para los economistas. Sólo si son destruidas, sólo al surgir una percepción social de que la economía ha entrado en colisión con la ecología, sólo entonces algún que otro economista empieza a musitar algo acerca de las "externalidades" y la atribución de "derechos de propiedad" sobre la naturaleza.

Se evidencia que la contabilidad ambiental en Colombia no es vinculante para las personas públicas y privadas, y consecuencia de lo precedido, es la complejidad de incorporar el valor de los bienes y servicios ambientales, el costo económicos de los daños, degradación y deterioro ambiental y el valor económico de los recursos naturales renovables como activos propios; bajo este enfoque se recomienda por parte del Congreso de la República de Colombia, presentar, tramitar y aprobar una ley para convertir la contabilidad ambiental en una realidad legal al interior de las entidades.

De igual manera, otra estrategia para ayudar a resolver el problema de contaminación ambiental como consecuencia de la falta de planificación ambiental, es gravar mediante una ley a todas las empresas a pagar por la contaminación que generen en todos los recursos, exactamente igual que pagan por la mano de obra de sus trabajadores, las materias primas y los servicios públicos que utilizan; incluir el valor del pago de los instrumentos económicos ambientales en sus costos fijos.

Esto en desarrollo del principio 16 de la Declaración de Río de Janeiro sobre Medio Ambiente y Desarrollo de junio de 1992 que expresa que los Estados deben procurar internalizar los costos ambientales y el uso de instrumentos económicos, sobre el criterio de 
que el que contamina debe, en principio, cargar con los costos de la contaminación.

(Cardena, 2001)

Los proyectos de ley que se proponen, tienen como finalidad disminuir los impactos de las externalidades negativas que generan las instituciones en el desarrollo de los procesos de producción, es decir enfocar nuestro actuar en la responsabilidad social ambiental.

En estas circunstancias (Mochón, 2005) afirma que "El Estado puede internalizar la externalidad gravando los bienes y servicios que generan externalidad negativa", debiendo realizar la valoración de los recursos naturales renovales (agua, fauna, flora, suelo, aire, etc.) por la utilización y/o alteración de los mismos, teniendo en cuenta los factores sociales, ambientales y económicos, soportado en la aplicación del principio universal "el que contamina paga"; siendo una forma de lograr cambiar el comportamiento respecto al medio ambiente, siendo consecuencia de alterar la relación costo/beneficio asociada a la actividad de contaminar y/o utilizar los recursos naturales renovables. Caso concreto para Colombia, fijar instrumentos económicos ambientales para la utilización y afectación a los recursos naturales aire y suelo.

Es en este sentido, se recomienda proferir una ley de la república para estipular que la intervención de cada recurso natural renovable, se haya fijado y cancelado el pago por el deterioro ambiental; es decir fijar instrumentos económicos ambientales a todos los recursos naturales y mayor valor a los existentes que desestimule su intervención o aprovechamiento. Verbi gracia: Para los permisos de emisiones atmosféricas, no existe norma que cobre una tasa por el uso de la atmosfera, no vale nada afectar ni contaminar el aire con emisiones de material particulado; en este sentido es importante reglamentar la tasa por uso del aire.

La ley 1753 de 2015 - Plan Nacional de Desarrollo- en su artículo 33, inciso tercero creó el peaje por congestión o contaminación, así:

Los municipios o distritos mayores a 300.000 habitantes, en concordancia con las competencias de los concejos municipales o distritales, podrán establecer tasas, diferentes a los peajes establecidos en la Ley 105 de 1993, por acceso a áreas de alta congestión, de infraestructura construida para evitar congestión urbana, así como por contaminación, con base en la reglamentación que el Gobierno Nacional expida para el efecto. Los recursos obtenidos por concepto de las tasas adoptadas por las mencionadas entidades territoriales, 
se destinarán a financiar proyectos y programas de infraestructura vial, transporte público y programas de mitigación de contaminación ambiental vehicular.

De otra parte, se excluye de la recomendación planteada la tasa al recurso hídrico, el cual cuenta con su reglamentación propia para el cobro económico a favor del Estado frente a su uso y disposición de vertimientos, así: tasa retributiva, valor económico que el usuario cancela ante la autoridad ambiental por vertimientos líquidos y sólidos a las fuentes hídricas o al suelo; y la tasa por uso del agua, valor económico que se cancela por la captación del recurso hídrico dentro de una concesión de agua superficial o subterráneas otorgada por parte de la autoridad ambiental; al respecto se recomienda por parte del Ministerio de Ambiente y Desarrollo Sostenible realizar una revisión técnica y jurídica a la reglamentación legal existente sobre el tema y actualizar los conceptos, formulas y valores a cancelar por los usuarios.

A hoy el cobro de la tasa por uso del agua en ocasiones son valores irrisorios a cobrarse por parte de la autoridad ambiental, no existiendo punto de equilibrio entre la generación de la factura, su expedición, entrega y trámite de notificaciones frente al valor muy mínimo a pagar por el usuario por concepto del uso del agua; de ahí la necesidad de aumentarse el valor a pagar por concepto de tasa por usa el agua.

Por otro lado, el recurso flora tiene su fundamento legal en el Acuerdo proferido por el Inderena, para poder cobrar la tasa por los aprovechamientos forestales por parte de las autoridades ambientales; a diferencias, que en muchas entidades ambientales no realicen el cobro ordenado. En este sentido, se recomienda al Ministerio de Ambiente y Desarrollo Sostenible expida un decreto por el cual se actualice el cobro de la tasa por uso de la fauna y la flora y se deje sin efecto la reglamentación del Inderena sobre el tema a hoy existente.

En este orden de ideas y de acuerdo a lo trascrito, puede afirmarse que se busca que las empresas siempre tengan un incentivo económico para disminuir emisiones o disminuir la utilización de los recursos naturales renovables y lograr alcanzar resultados empresariales y ambientales al menor costo posible.

En este sentido y aunado a lo precedente, es deber del Ministerio de Ambiente y Desarrollo Sostenible cumplir sus funciones como rector de la gestión del ambiente y de los recursos naturales renovables, en concordancia con la planificación ambiental contemplada en el 
artículo 80 de la Constitución Política y lo dispuesto en el artículo $2^{\circ}$, numerales $7^{\circ}$ y $8^{\circ}$ del decreto 3570 de 2011, en coherencia con el tema, así:

7. Evaluar los alcances y efectos económicos de los factores ambientales, su incorporación al valor de mercado de bienes y servicios y su impacto sobre el desarrollo de la economía nacional y su sector externo; su costo en los proyectos de mediana y grande infraestructura, así como el costo económico del deterioro y de la conservación del medio ambiente y de los recursos naturales renovables. $Y$, 8. Realizar investigaciones, análisis y estudios económicos y fiscales en relación con los recursos presupuestales y financieros del sector de gestión ambiental, tales como, impuestos, tasas, contribuciones, derechos, multas e incentivos con él relacionados; y fijar el monto tarifario mínimo de las tasas por el uso y el aprovechamiento de los recursos naturales renovables, de conformidad con la ley.

\subsubsection{Como lo vamos a utilizar? Ordenamiento Ambiental}

Dando cumplimiento a la estructura planteada como solución al problema de la investigación, y en busca de dar contestación al interrogante de cómo vamos a gastar los recursos naturales renovables existentes en nuestro país y en avenencia con lo examinado en el Decretoley 2811 de 1974 en el literal c) del artículo 45, el cual señala:

Cuando se trate de utilizar uno o más recursos naturales renovables o de realizar actividades que puedan ocasionar el deterioro de otros recursos o la alteración de un ecosistema, para su aplicación prevalente de acuerdo con las prioridades señaladas en este Código o en los planes de desarrollo, deberán justipreciarse las diversas formas de uso o de medios para alcanzar este último, que produzcan el mayor beneficio en comparación con el daño que puedan causar en lo ecológico, económico y social.

Precisamos que la propuesta recomendada consiste en que el Ministerio de Ambiente y Desarrollo Sostenible - MADS realice un estudio integral y un mapa de riesgos ambiental nacional (M.RAN) donde se identifiquen los posibles factores de deterioro, afectaciones ambientales y pasivos ambientales (ley 1753 de 2015, art. 251), por cada uno de los recursos naturales renovables y analizar las causas e intervenciones a los componentes ambientales; precisando finalmente las alternativas para evitar o minimizar estos factores de deterioro ambiental y la recuperación o restauración de las áreas intervenidas o afectadas, sin ser un 
obstáculo para el desarrollo de las obras o proyectos en armonía con el desarrollo sostenible moderno.

Lo anteriormente planteado, debe ser coordinado por el Ministerio de Ambiente y Desarrollo Sostenible y articulado con los otros ministerios afines, la autoridad nacional de licencias ambientales, parques nacionales naturales, procuraduría y fiscalía general de la Nación, policía nacional, corporaciones autónomas regionales, departamentos y asambleas departamentales, grandes centros urbanos y áreas metropolitanas (autoridad ambiental, siempre y cuando superen un millón de habitantes urbanos), establecimientos públicos de los distritos especiales de Cartagena, Barranquilla, Santa Marta y Buenaventura y los entes territoriales municipales.

El mapa de riesgos ambiental nacional (M.RAN), inicia con la colecta de información en todo el país y su posterior análisis en dos líneas; la primera: La tabulación de las causas ambientales que dieron origen a todos los procesos administrativos sancionatorios y los cargos formulados dentro de estos procesos iniciados por las autoridades ambientales en todo el territorio nacional Colombiano, y la segunda: La tabulación de las causas que dieron origen a los procesos penales por delitos ambientales en todas las fiscalías del país.

Se recomienda apoyarse con un formato único o un sistema operativo que elabore el Ministerio de Ambiente (MADS), donde las entidades en todos los órdenes diligencien lo solicitado, y posteriormente el análisis de la información por recursos naturales renovables de forma individual y las conclusiones respectivas sea diligenciadas por el Ministerio de Ambiente y Desarrollo Sostenible siendo parte del resultado del cumplimiento de las funciones asignadas, en especial lo contemplado en el decreto 3570 de 2011, artículo $2^{\circ}$, numerales 2, 3, y 6 que enseñan:

1. Diseñar y formular la política nacional en relación con el ambiente y los recursos naturales renovables, y establecer las reglas y criterios de ordenamiento ambiental, para asegurar su conservación y el aprovechamiento sostenible de los recursos naturales renovables y del ambiente. $Y$, 2. Diseñar y regular las políticas públicas y las condiciones generales para el saneamiento del ambiente, y el uso, manejo, aprovechamiento, conservación, restauración y recuperación de los recursos naturales, a fin de impedir, reprimir, eliminar o mitigar el impacto de actividades contaminantes, deteriorantes o 
destructivas del entorno o del patrimonio natural, en todos los sectores económicos y productivos.

3. Apoyar a los demás Ministerios y entidades Estatales, en la formulación de las políticas públicas, de competencia de los mismos, que tengan implicaciones de carácter ambiental y desarrollo sostenible, y establecer los criterios ambientales que deben ser incorporados en esta formulación de las políticas sectoriales. Y, 6. Preparar, con la asesoría del Departamento Nacional de Planeación, los planes, programas y proyectos que en materia ambiental, o en relación con los recursos naturales renovables y el ordenamiento ambiental del territorio, deban incorporarse a los proyectos del Plan Nacional de Desarrollo y del Plan Nacional de Inversiones que el Gobierno someta a consideración del Congreso de la República.

En aproximaciones al tema es lo contemplado en el decreto 1200 de 2004 en lo referente al componente del diagnóstico ambiental del PGAR en lo regional, y lo acordado en la ley 1253 de 2008, la cual precisó en su artículo $2^{\circ}$ que "El Gobierno Nacional velará porque la formulación y ejecución de políticas y programas que tengan impacto en la productividad y competitividad se desarrolle mediante la adecuada coordinación de las entidades del sector privado, la academia y el sector público". Importante el tema por fijar una sinergia de coordinación entre el sectores público y las empresas privadas, para orientar la productividad y competitividad, retomando lo dispuesto del decreto 2828 de 2006 hoy derogado por el decreto 1500 de 2012.

Si bien no se menciona en el texto de esta ley, el componente del crecimiento sostenible, se prevé que debe ir implícito las obligaciones de planificación y proteccionistas ambientales del Estado; en su defecto, se recomienda reformar la presente ley como fuente del derecho e incluir un párrafo, que puntualice que: La productividad y competitividad se desarrollará garantizando la responsabilidad social, ambiental y económica del país, fundado en el desarrollo sostenible moderno.

Analizada la legislación ambiental expuesta en los capítulos anteriores, y revisando que instrumentos ambientales existen para las empresas, es ahí donde nos encontramos con la obligatoriedad de la conformación de los departamento de gestión ambiental - DGA, definido como una área especializada, dentro de la estructura organizacional de determinadas empresas a 
nivel industrial responsable de garantizar el cumplimiento ambiental de conformidad con lo establecido en el decreto 1299 de 2008.

Lo postulados normativos precedentes en comparación con la realidad del actuar empresarial no son los ideales; se precisa que el autocontrol ambiental por parte de las empresas es débil y $\sin$ desconocer los efímeros programas de responsabilidad social ambiental, las sanciones administrativas impuestas por afectaciones ambientales al entorno sensible y los incumplimientos normativos son reiterativos por parte de las empresas, todo focalizado al desmejoramiento continuo de la calidad de vida de los habitantes; lo anterior justifica identificar el porqué de este actuar por parte de las empresas e industrias en Colombia? aspecto que debe ser analizado dentro del mapa de riesgos ambiental nacional (M.RAN).

Así mismo, se recomienda realizar una modificación al decreto 1299 de 2008, para ampliar la obligatoriedad de los departamentos de gestión ambiental - DGA a diferentes sectores empresariales como instrumento de auto control y auto gestión ambiental y que se cumplan funciones de control interno ambiental al interior de las instituciones.

De otra parte, en el contexto internacional se han planteado propuestas de cómo gastar los recursos naturales renovables, y una de ellas es la economía verde en el contexto del desarrollo sostenible, como resultado de la conferencia de las naciones unidas sobre el desarrollo sostenible «Rio+20» 2012, y consagrado en el documento final denominado "el futuro que queremos", puntualmente en el numeral 56, así:

Cada país dispone de diferentes enfoques, visiones, modelos e instrumentos, en función de sus circunstancias y prioridades nacionales, para lograr el desarrollo sostenible en sus tres dimensiones, que es nuestro objetivo general. A este respecto, consideramos que una economía verde en el contexto del desarrollo sostenible y la erradicación de la pobreza es uno de los instrumentos importantes disponibles para lograr el desarrollo sostenible y que podría ofrecer alternativas en la formulación de políticas pero no debe consistir en un conjunto de normas rígidas. Ponemos de relieve que una economía verde debe contribuir a la erradicación de la pobreza y al crecimiento económico sostenido, aumentando la inclusión social, mejorando el bienestar humano y creando oportunidades de empleo y trabajo decente para todos, manteniendo al mismo tiempo el funcionamiento saludable de los ecosistemas de la Tierra. 
De lo anteriormente dicho, se desprende que debemos implementar las recomendaciones internacionales en materia ambiental, caso concreto aplicar la economía verde en armonía con la contabilidad ambiental y enfocada a la planificación en el manejo y aprovechamiento de los recursos naturales renovables. Así mimo, se recomienda incentivar procesos productivos y de consumo que tiendan a evitar la disipación energética y de recursos e incentivar el desarrollo de nuevas técnicas y procesos de fabricación y productos más limpios, fomentando los mercados verdes.

Por último, se recomienda realizar la ordenación de la totalidad de las cuencas hidrográficas del país, el ordenamiento ambiental de uso del territorio y de los mares contiguos en toda Colombia, realizar el plan de ordenación forestal nacional, el ordenamiento de los páramos, y en fin, la ordenación de cada uno de los recursos naturales renovables, bajo el enfoque de la planificación en el manejo y aprovechamiento sostenible de los recursos naturales renovables y del ambiente.

\subsection{4 ¿Con qué lo vamos a recuperar? Política Ambiental Preventiva}

Con toda atención debemos dar respuesta al interrogante como vamos a recuperar los recursos naturales renovables intervenidos bajo el soporte de la planificación ambiental; empero antes debemos referirnos a lo dispuesto en el decreto 3570 de 2011, que consagra las funciones sobre el tema aludido por parte del Ministerio de Ambiente y Desarrollo Sostenible (artículo $2^{\circ}$, numerales $11,13,16,17$ y 18), así:

11. Coordinar, promover y orientar las acciones de investigación sobre el ambiente y los recursos naturales renovables y sobre modelos alternativos de desarrollo sostenible.13. Diseñar y formular la política, planes, programas y proyectos, y establecer los criterios, directrices, orientaciones y lineamientos en materia de áreas protegidas, y formular la política en materia del Sistema de Parques Nacionales Naturales. 16. Expedir los actos administrativos para la delimitación de los páramos.

17. Adquirir, en los casos expresamente definidos en la Ley 99 de 1993, los bienes de propiedad privada y los patrimoniales de las entidades de derecho público; adelantar ante la autoridad competente la expropiación de bienes por razones de utilidad pública o interés social definidas por la ley, e imponer las servidumbres a que hubiese lugar.18. Constituir con otras personas jurídicas de derecho público o privado, asociaciones, fundaciones o 
entidades para la conservación, manejo, administración y gestión de la biodiversidad, promoción y comercialización de bienes y servicios ambientales, velando por la protección del patrimonio natural del país.

$\mathrm{Al}$ respecto vale la pena traer a colación el contenido del artículo $7^{\circ}$ del decreto 3570 de 2011, en el cual se estipularon las funciones de la dirección general de ordenamiento ambiental territorial y coordinación del SINA, entre ellas, las siguientes:

3. Apoyar y coordinar los procesos de planificación de las autoridades ambientales, en coordinación con la Oficina Asesora de Planeación del Ministerio. Y, 7. Aportar los elementos técnicos, en el ámbito de su competencia, para la formulación de la política y planificación del ordenamiento territorial.

De igual manera el artículo $9^{\circ}$ del decreto en mención, estableció las funciones de la Oficina de negocios verdes y sostenibles del MADS, entre ellas, las siguientes:

8. Desarrollar metodologías en conjunto con las dependencias del Ministerio que permitan la valoración económica del deterioro y la conservación del ambiente y de los recursos naturales renovables. 9. Realizar estudios y diseñar instrumentos e incentivos económicos para el control de la contaminación, la restauración, la conservación y el manejo sostenible de los recursos naturales renovables. 10. Preparar los estudios para la fijación del monto tarifario mínimo de las tasas retributivas y compensatorias, de acuerdo con las normas legales vigentes. 11. Proponer los cálculos económicos para el pago o reconocimiento de los derechos o regalías que se causen a favor de la Nación por el uso de recursos genéticos. $Y$, 12. Promover el uso sostenible.

Bajo esa lluvia de funciones, es en este espacio donde nos corresponde precisar que de las anteriores funciones asignadas al Ministerio de Ambiente y Desarrollo Sostenible MADS deben tener un hilo conductor dirigido a la planificación ambiental nacional; y es en este sentir que damos respuesta al interrogante ¿cómo vamos a recuperar los recursos naturales renovables afectados e intervenidos?.

$\mathrm{Al}$ respecto, se propone crear una política ambiental preventiva (PAP) establecida frente a la intervención de cada uno de los recursos naturales renovables, para cumplirse antes de la 
expedición de cualquier permiso, autorización o licencia ambiental; entre los lineamientos ambientales propuestos, presentamos los siguientes:

Suspender cualquier trámite de concesión de aguas superficial o subterráneas, permisos de vertimientos, permiso de ocupación de cause o cualquier trámite o autorización referente al recurso hídrico hasta que la respectiva cuenca hidrográfica este ordenada y reglamentada ambientalmente.

$\checkmark$ Prohibir las talas en el recurso flora en todo el territorio nacional; salvo excepciones, entre ellas: cuando se encuentren árboles caídos o muertos por causas naturales, o que por razones de orden sanitario debidamente comprobadas requieren ser talados o estén causando perjuicio a la estabilidad de los suelos, a canales de agua, andenes, calles, obras de infraestructura o edificaciones. Frente a la prohibición nacional de talar los árboles, la regla general propuesta es la de trasplantar o realizar la reubicación arbórea.

Fijar de forma obligatoria las compensaciones previas; es decir toda compensación ambiental fijada por la intervención de algún recurso natural renovable debe cumplirse de forma anticipada al permiso o licencia ambiental, salvo excepciones.

$\checkmark$ Crear como requisito previo, la obligatoriedad de exigir la certificación previa ambiental favorable emitida por la autoridad ambiental como trámite para la expedición de licencias de construcción, e igual para el otorgamiento de títulos mineros o contratos de concesión minera.

Es decir, debe primar el respeto, cuidado y preservación de los ecosistemas frágiles y estratégicos, áreas protegidas locales, regionales y nacionales, en el entendido de la labor armónica entre las diferentes instituciones del Estado (autoridades ambientales, mineras y oficinas de planeación y/o curadurías urbanas).

Lo precedente como resultado de existir en la realidad muchas licencias de construcción emitidas sin haberse analizado la protección o restricciones ambientales; y caso similar, existen títulos o concesiones mineras otorgados en ecosistemas de páramos y áreas protegidas, que al 
realizarse su exploración o explotación afectarían de forma grave los recursos naturales renovables.

$\checkmark$ Posterior a los resultados de los procesos de planificación ambiental nacional, e identificada la situación actual de la minería en ecosistemas frágiles, es deber de las autoridades ambientales radicar demandas de controversias contractuales contra los contratos de concesión minera o revocatorias directas en contra de los títulos mineros por "objeto ilícito sobreviniente", al estar ubicados en áreas protegidas o ecosistemas de páramos.

$\checkmark$ Crear e implementar el Certificado de Antecedentes Ambientales Nacional (CAAN), como requisito previo para cualquier trámite ambiental y Estatal; es decir, si un usuario tiene pendientes, compensaciones o multas ambientales, debe primero estar a paz y salvo con las autoridades ambientales a nivel nacional, para poder continuar con el trámite ambiental respectivo y poder realizar cualquier procedimiento ante las entidades Estatales de cualquier orden y jurisdicción. Se podrá obtener en línea (página www.minambiente.gov.co) y no tendrá ningún valor económico.

Fomentar el desarrollo de una política fiscal de apoyo a la investigación ambiental, programas ambientales y desarrollo de la responsabilidad social empresarial con una muy fuerte incentivación a la participación del sistema de investigación enfocada al desarrollo sostenible moderno.

$\checkmark$ Entre otras propuestas que busquen mejorar la calidad de vida presente.

\subsubsection{Qué vamos a entregar a cambio? La Responsabilidad Social Ambiental}

Como consecuencia de la inexistencia de un marco legal propio y vinculante frente a la planificación ambiental para que las instituciones realicen actividades dentro de la responsabilidad ambiental y social; pero pretendiendo profundizar de forma sistémica aplicando la hermenéutica jurídica, precisamos que existen vacíos en el conocimiento frente a la planificación en el manejo y aprovechamiento de los recurso naturales como responsabilidad ambiental del Estado, en todos los escenarios públicos y privados, nacionales e internacionales, 
concatenados a las constantes afectaciones y deterioros ambientales de todos nuestros recursos naturales renovables e improvisación de políticas ambientales a nivel nacional y regional.

Lo anteriormente afirmado, se desprende de las respuestas allegadas por diferentes entidades públicas nacionales y regionales que cumplen funciones ambientales, frente a cuestionarios realizados por el suscrito y radicados bajo la figura del derecho de petición sobre el tema objeto de la investigación.

En contexto similar y de la revisión normativa ambiental realizada en los dos primero capítulos, no se evidenció que existan obligaciones vinculantes frente a la planificación ambiental empresarial para el sector privado; coexisten las bases para reglamentar la responsabilidad social ambiental empresarial, que a hoy, solo se da en forma voluntaria por un mínimo de compañías, posiblemente por su imagen corporativa positiva, buen nombre - good will, compromiso interno ambiental, fidelidad de sus clientes, mercadeo, prácticas que generan estímulos financieros, cohesión social, autocontrol, entre otras. En fin, cada empresa tendrá su fundamentación, teoría y práctica propia.

Colombia formó una asociación llamada Consejo Empresarial Colombiano para el Desarrollo Sostenible (CECODES), es el capítulo similar y aplicación del Consejo Empresarial Mundial para el Desarrollo Sostenible (WBCSD) por sus siglas en inglés, que reúne a 200 compañías líderes en el mundo, unidas por el compromiso con el desarrollo sostenible a través de sus tres pilares: crecimiento económico, balance ecológico y progreso social. En Colombia está conformado por un grupo de empresas convencidas que el desarrollo sostenible es una opción para lograr una mayor rentabilidad, mejorar la calidad de vida de las personas y utilizar racionalmente los recursos naturales (CECODES, 2014); importante el tema, a fin de lograr permear en la asociación y aunar esfuerzos para lograr la planificación en el manejo y utilización de los recursos naturales renovables.

En nuestro país, el Centro Colombiano de Responsabilidad Social Empresarial, la define como "la capacidad de respuesta que tiene una empresa o una entidad, frente a sus efectos e implicaciones de sus acciones sobre los diferentes grupos con que se relaciona (stakeholders o socios de valor)". Una empresa es socialmente responsable cuando las actividades que realiza se orientan a la satisfacción de las necesidades y expectativas de sus integrantes, de la sociedad y de 
quienes se benefician de su actividad comercial, así como también, al cuidado y preservación del entorno.

El Instituto Colombiano de Normas técnicas, Icontec, después de un proceso consultivo y técnico al más alto nivel, creó el grupo técnico GT 180 y posteriormente, el documento integrador GTC 180 define la responsabilidad social de la siguiente manera:

Es el compromiso voluntario y explícito que las organizaciones asumen frente a las expectativas y acciones concertadas que se generan con las partes interesadas (stakeholders), en materia de desarrollo humano integral; esta permite a las organizaciones asegurar el crecimiento económico, el desarrollo social y el equilibrio ambiental, partiendo del cumplimiento de las disposiciones legales.

Mentada la problemática ambiental y la ausencia de la planificación en el manejo y aprovechamiento de los recursos naturales renovables registradas día a día en los diferentes medios de comunicación, se hace necesario participar lo publicado en el periódico (Vanguardia Liberal, 2014) sobre el tema, así:

Colombia es el país con más conflictos ambientales del continente: Según la Corte Constitucional, la tala de bosques, los daños a las fuentes hídricas y la minería ilegal entre otros, hicieron que el atlas global de justicia ambiental ubicara a Colombia como el país que más conflictos ambientales enfrenta en el continente.

Frente al interrogante planteado, ¿Qué vamos a entregar a cambio, por la utilización, aprovechamiento, deterioro o afectación de los recursos naturales? se propone implementar la responsabilidad social ambiental empresarial -RSAE- en Colombia; una vez se realice su trámite legislativo y sanción presidencial fundado en la planificación ambiental, se convertiría el tema en una realidad vinculante para todas las empresas que tenga dentro de sus activos recursos naturales renovables (agua, fauna y flora, etc.) o con su labor, actividad y en desarrollo de su objeto social necesite intervenir algún recurso natural y deban realizar trámite ambiental para obtener el permiso, autorización o licencia ambiental respectiva.

En este sentido lineal, se enfocaría la responsabilidad social ambiental empresarial:

$\checkmark$ Aplicación del concepto de desarrollo sostenible moderno por parte de las empresas y del Estado 
$\checkmark$ Crear la obligación empresarial para que inviertan recursos en construir parques públicos, parques lineales, apadrinar los parques ya existentes. Meta: Mayor Espacios verdes públicos para la comunidad que ofrecen servicios ambientales.

$\checkmark$ Implementar la obligación de realizar siembra de compensaciones en franjas de protección, rondas de río, taludes o borde de escarpas, áreas comunes y de uso público, corredores biológicos, áreas protegidas y compra de predios con riquezas naturales (nacimientos hídricos).

$\checkmark$ Adquisición del 100\% de los predios ubicados en todas las áreas protegidas nacionales, regionales y locales y ecosistemas de páramos.

$\checkmark$ Recuperación de áreas intervenidas y pasivos ambientales en busca de tener corredores ecológicos sin fraccionamiento.

$\checkmark$ Good will ambiental empresarial.

$\checkmark$ Implementar los mercados verdes como obligación empresarial.

$\checkmark$ Incentivos económicos y sociales para las empresas que apliquen la RSAE. En armonía con los existentes, entre ellos el incentivo al aprovechamiento viable de residuos sólidos (ley 1753 de 2015 - Plan Nacional de Desarrollo- art. 88)

$\checkmark$ Promover el sello ecológico o certificación verde responsable, que será un medio de promoción, difusión y calidad sobre la gestión en la materia ambiental de cada empresa.

$\checkmark$ Exclusión del pago de impuesto predial a los inmuebles que estén dentro de un área protegida y el predio este cumpliendo un bien o servicio ambiental en su integridad.

$\checkmark$ Incorporación de tecnologías amigables con el entorno y la adopción de mecanismos para una operación limpia

$\checkmark$ Implementar el continuo compromiso ambiental o "constant environmental commitment". Nos encontramos frente a la teoría propuesta del "corazón ambiental empresarial", traducido al sentimiento y compromiso vinculante del empresario para conservar y preservar los recursos naturales renovables.

En relación con lo anterior, precisamos que esta investigación plantea la aplicación de la responsabilidad social ambiental empresarial - RSAE implicando que la relación de las organizaciones con la sociedad, sea un compromiso prioritario con el ambiente, los recursos naturales renovables y el desarrollo sostenible, soportado en la planificación ambiental. 
Finalizando, puntualizamos que la responsabilidad social ambiental en Colombia es un sentimiento, no tiene soporte Constitucional ni legal, es sencillo extraer que las autoridades ambientales no puedan exigir políticas ambientales definidas al interior de las empresas e industrias. En este sentido, se recomienda radicar por parte del Gobierno Nacional o con el acompañamiento activo en su trámite un proyecto de ley denominado "Por el cual se crea la responsabilidad social ambiental empresarial -RSAE- en Colombia”, con soporte de lo planteado en la presente investigación y en desarrollo de la función social y ambiental de la propiedad privada, y sistémicamente relacionado con la libertad de la actividad económica y la iniciativa privada, dentro de los límites del bien común y ecológico como un derecho con sus respectivas responsabilidades, intrínsecamente la ambiental (artículo 333 Constitución Política).

Por ello, se recomienda la designación e implementación al interior de las organizaciones una línea exclusiva para definir la política, los planes estratégicos y programas a trazar transversalmente al interior de la factoría frente al tema de la responsabilidad social empresarial (ciclo PHVA - planear, hacer, verificar y actuar), incluyendo y puesta en funcionamiento fehacientemente del entorno ambiental (Departamento de Gestión Ambiental - DGA), su seguimiento a la gestión y la respectiva evaluación frente al tema, como se expuso anteriormente.

Parte del problema, es que el Gobierno no ha sido capaz de ver la política ambiental más allá de la lógica de la conservación más estricta. "La supervivencia siempre ha sido crear áreas protegidas, con el sentido de que adentro todo queda prohibido. Eso está muy bien para el 15 por ciento [del país protegido como parques nacionales], pero el otro 85 por ciento es imposible aplicarlo y, sin una verdadera planificación y gestión, solo se exacerban los conflictos sociales”.

Aunado a lo anterior, se recomienda eternizar las declaratorias de reservas de los recursos naturales renovables, como expensas de vida para el futuro próximo, con fundamento en el artículo 47 del Código de los Recursos Naturales Renovables (Decreto- Ley 2811 de 1974), así:

Consagra la posibilidad de declarar reservada una porción o la totalidad de los recursos naturales renovables de una región, cuando se presente alguna de las siguientes circunstancias: cuando sea necesario para organizar o facilitar la prestación de un servicio público; cuando se deban adelantar programas de restauración, conservación o preservación de esos recursos y del ambiente, o cuando el Estado resuelve explotarlos directamente. La Corte Constitucional, señalo que la facultad de hacer reservas para el 
manejo, conservación o restauración de los recursos naturales renovables, para satisfacer necesidades de interés público y social, se deriva de la titularidad del Estado sobre tales recursos, y aunque la Carta no se refiere expresamente a las reservas de recursos naturales, estas tienen fundamento constitucional en los artículos 8, 63, 79 y 80 incisos 1 y 2. (Ponce de León, 2005, Pp. 52 y 53)

Sin duda sobre el tema, se adiciona que la responsabilidad social empresarial previene los riesgos sociales que se pueden traducir en demandas, litigios, sanciones, excesiva regulación gubernamental, pérdida de imagen y mercado, conllevando secuencias en el presente y no permitiendo un pronóstico favorable para el futuro. 


\section{REFLEXIONES FINALES}

En conclusión y recordando lo dicho anteriormente, se observó la extensa artillería legal y Constitucional ambiental en Colombia y las funciones de las diferentes autoridades públicas ambientales. El espíritu normativo Constitucional de 1991 es excelente pero su aplicación es parcial; la Carta política trae un piso ambiental sólido compuesto por treinta y cinco (35) artículos que hemos denominado "La Constitución Verde de Colombia", y que representa una dualidad en el sentido de que fue calificado por la Corte Constitucional como un derecho-deber, por cuanto exige de las autoridades y de los particulares obligaciones y acciones encaminadas a su control, protección y conservación.

Entre los postulados Constitucionales, se vislumbra que la educación ambiental es un derecho y busca formar a las personas para la protección del ambiente. En paralelo, se evidencia que en muchos colegios o universidades este tema es irrelevante, en el mejor de los casos la asignatura o catedra denominada ambiental, los docentes la utilizan para que sus alumnos recojan residuos sólidos en los establecimientos educativos y fin al respecto, no existe una planificación al respecto; perdiéndose la esencia que es concienciar y formar al estudiante con criterios de respeto a la protección, conservación, restauración y preservación de la naturaleza; se recomienda realizar una revolución educativa ambiental con énfasis en investigación, propositiva y aplicada obligatoriamente desde la primaria, secundaria y pregrado .

Amplia normativa legal y Constitucional, pero vemos que es un tema ausente de brillo frente a la efectividad de las acciones ambientales; y sin profundizar en el contexto que nos rodea, se evidencian las constantes afectaciones y deterioros ambientales y la escasez de los recursos naturales renovables, hoy de moda, la sequía y ausencia del preciado líquido "agua" en ciertos lugares de la geografía Colombiana.

La problemática actual enunciada es el reflejo del incumplimiento por parte del Estado a ciertos postulados Constitucionales, por la inexistencia de reglamentación legal; refiriéndonos puntualmente a lo dispuesto en el artículo 80, de la obligación que le corresponde al Estado Colombiano de realizar la planificación en el manejo y aprovechamiento de los recursos naturales renovables nacional, enfocado primordialmente a garantizar el desarrollo sostenible moderno, la conservación, protección y la restauración del ambiente. 
En este sentido, se propone dar trámite normativo para reglamentar el cumplimiento obligatorio del postulado Constitucional (art. 80), y se recomienda la creación de un Sistema de Planificación Ambiental Nacional - SPAN para que las autoridades públicas que ejercen funciones ambientales lo implementen a fin de lograr la planificación en el manejo y aprovechamiento de los recursos naturales, iniciando por lo local, regional a llegar al contexto nacional; so pena de acciones disciplinarias por omisión e instauración de acciones de cumplimiento, entre otras.

Bajo esta perspectiva de la protección ambiental, se planteó la necesidad de una estructura legal propuesta sobre la planificación ambiental como un sistema de gestión gerencial, incorporada en la política pública nacional, la cual debe contener: (I) La elaboración de un diagnóstico nacional de los recursos naturales renovables, sus cantidades y estado de los mismos (condición actual), el inventario de los pasivos ambientales, identificación de las causas y factores del deterioro ambiental, lo anterior contenido en la creación del Mapa de Riesgos Ambiental Nacional (M.RAN); seguido, (II) la incorporación de la contabilidad ambiental, (III) el ordenamiento para cada uno de los recursos naturales renovables (agua, suelo, aire, fauna, flora, paisaje), (IV) la incorporación de políticas previas Estatales ambientales y (V) la aplicación de la responsabilidad social ambiental - RSA.

Como punto de partida del desarrollo del Sistema de planificación ambiental, se realizaría por parte de las diferentes autoridades ambientales un diagnóstico local, regional y nacional de los diferentes recursos naturales renovables, y se definiría el límite y niveles que marcan el equilibrio ecológico y la capacidad de carga de los ecosistemas; así, podría proferirse resoluciones por parte del Ministerio de Ambiente y Desarrollo Sostenible (MADS) sobre los recursos naturales renovables, las cantidades y especies permitidas para el manejo y aprovechamiento de los recursos naturales sin afectar el desarrollo sostenible moderno.

La planificación ambiental busca el equilibrio entre el desarrollo económico y el medio natural, de manera que los recursos naturales renovables continúen disponibles para el presente (patrimonio ecológico), en cantidad suficiente, con una buena calidad, de manera que se refleje en el mejoramiento de la calidad de vida y sobre todo que su disponibilidad sea en igualdad de condiciones para toda la sociedad; en este sentido, la definimos: La planificación ambiental, es un instrumento de gestión de las autoridades públicas con funciones ambientales, que lleva implícito la 
obligación de realizar un inventario de la existencia de los recursos naturales renovables, su manejo integral y utilización sostenible prolongado en el tiempo, manteniendo su equilibrio ecológico.

Frente a otro aspecto, se precisa que el ser humano es el bien ecológico $\mathrm{N}^{\circ} 1$, en este sentido, se recomienda expedir la nueva reglamentación o normatividad ambiental en temas sobre la planificación ambiental y la responsabilidad social ambiental, llámese leyes, decretos, resoluciones, circulares, políticas, tratados, fundado en la "Valoración Humana"; es saber, que nuestra vida es la mayor riqueza ambiental sobre el planeta, que debemos respetar nuestra dignidad humana, el verdadero respeto al derecho fundamental de un ambiente sano en conexidad con nuestra vida.

Como exigir cuidar la fauna y la flora, cuando no se quiere, ni se cuida la vida humana? Es promover en positivo la conservación y restauración del ambiente, es enfocar el cuidado y protección de los recursos naturales renovables, como un buen negocio económico, cuidar nuestra casa ambiental vale la pena, todo enfocado para preservar el primer bien ecológico "El Ser Humano"; previa planificación ambiental fijado por el Estado (artículo 80 CP).

Seguido, se recomienda renovar el concepto de desarrollo sostenible abordado por primera vez en (Informe Brundtland ,1987), y ratificado por la Corte Constitucional Colombiana como una "solidaridad intergeneracional", sugiriendo darle un giro al pensamiento de cuidar el ambiente para las generaciones del futuro; debemos pensar en un problema ambiental del presente, del hoy, del ya, del segundo que acaba de pasar, y es aquí donde se enuncia un nuevo concepto planteado y es el desarrollo sostenible moderno - DSM, así:

Son las actividades que satisfacen las necesidades de las generaciones presentes, respetando el límite del equilibrio ecológico previa planificación ambiental fijada por el Estado, enfocado al respeto de la vida humana presente, como bien ecológico esencial.

De otra parte, es evidente que existen diferentes autoridades ambientales y entidades que cumplen funciones ambientales (Nivel nacional, regional y local), olvidándose el concepto de la Corte Constitucional, frente a las funciones concurrentes en materia ambiental; pero no es suficiente, cada día continúan las afectaciones ambientales y la disminución de la calidad de vida. Ya no es un problema de futuro, es un problema del presente, no pensar en las generaciones futuras, es pensar en la sobrevivencia actual. 
Resulta claro en afirmar, que el marco jurídico de las autoridades ambientales, puntualmente las Corporaciones Autónomas Regionales, se recomienda su reforma, respecto a su estructura, administración y funciones, en busca de efectividad en su actuar y la primacía de los recursos naturales renovables fundado en la planificación ambiental del manejo y aprovechamiento de los recursos naturales renovables; al igual que asignar la función Constitucional de la planificación ambiental al Ministerio de Ambiente y Desarrollo Sostenible, como rector de la gestión del ambiente y de los recursos naturales renovables, partiendo de la importancia de realizar un inventario en el país por municipios, departamentos y regiones y por cada recurso natural individual; para reglón seguido, tener un diagnostico nacional, a fin de realizar una verdadera planificación ambiental.

Instar a la conformación del CODIGO UNICO NACIONAL AMBIENTAL - CUNA, con el cumplimiento de los principios Constitucionales ambientales (Planificación ambiental) e incentivos frente al tema; y, goce dentro de su estructura de un capítulo para cada recurso natural renovable; es decir, un capítulo para el recurso hídrico y sus permisos ambientales al respecto, otro capítulo para fauna, otro para flora, otro para suelo, otro para aire, entre otros, y cada uno con sus respectivas reglamentaciones en cuanto a la política nacional, sus trámites y procedimientos, y un capítulo final con la creación y reglamentación de los JUECES AMBIENTALES.

El tema de la creación de los jueces ambientales, es el resultado de la lectura previa a las funciones de las autoridad ambientales contenidas en la Constitución Política y la normatividad al respecto y donde quedaron evidenciadas un sinnúmero de entidades ambientales; y son las mismas instituciones quienes realizan la evaluación y emiten los permisos y autorizaciones ambientales, y quienes realizan los informes de seguimiento y evidencian las afectaciones ambientales e infracciones a las normas, y en determinadas ocasiones los procesos son archivados, es diferenciar la evaluación y seguimiento en cabeza de las autoridades ambientales y el otorgamiento de permisos y sanciones ambientales a cargo de la rama judicial. Lo precedente, en el entendido que los recursos naturales renovables tiene la importancia del derecho fundamental a la vida, soportado en el precepto Constitucional de la planificación del manejo y aprovechamiento de los recursos naturales. 
De otra parte, se puede afirmar que muy pocas empresas han venido desarrollando una gestión voluntaria encaminada en mejorar la calidad de vida de los usuarios, colaboradores, comunidades y habitantes en general. En el aspecto ambiental, las acciones deben estar dirigidas al uso racional de los recursos naturales renovables, mediante la incorporación de tecnologías amigables con el entorno y la adopción de mecanismos para una operación limpia, el reconocimiento y pago e incentivos económico para la actividad de preservación ambiental, el cumplimiento a las compensaciones ambientales y reforestaciones en espacio de interés general, entre otras. Podríamos definirlo como el "continuo compromiso ambiental" o "constant environmental commitment" o el inicio de la teoría del "corazón ambiental empresarial”. Se recomienda radicar por parte del Gobierno Nacional o con el acompañamiento activo en su trámite un proyecto de ley denominado "Por el cual se crea la responsabilidad social ambiental empresarial -RSAE- en Colombia”, con soporte de lo planteado en la presente investigación.

Así mismo, buscar voluntariamente amigos de la conservación y protección de los recursos naturales renovables, no es tan fácil; pero si logramos construir instrumentos legales vinculantes para que las factorías se conviertan en aliados de nuestras riquezas naturales, sería conveniente y tiene una alta relevancia social, estamos hablando de miles de empresas e industrias en Colombia, todas con un enfoque ambiental, todas coadyuvando a la recuperación del ambiente, todas con su "corazón ambiental empresarial”, esto implicaría un cambio de lo voluntario a lo vinculante para las empresas, de lo efímero a lo trascendental para nuestros ecosistemas, de lo insignificante a lo transversal para nuestra comunidad; todo redundaría en el mejoramiento y preservación de la calidad de vida del hoy, para garantizar la vida del mañana.

Aplicar el ciclo PHVA al sector público y privado bajo la órbita ambiental, es decir: PLANEAR (Identificación y línea base de sus prácticas y caracterización de la responsabilidad social empresarial, diseño e implementación de un plan estratégico de responsabilidad social empresarial), HACER (Configuración de la gestión de responsabilidad social empresarial, definición de ejes de trabajo y ejecutar por fases lo planificado), VERIFICAR (Construcción de un programa de seguimiento y control a la gestión y medición cuantitativa y cualitativa de la ejecución de la responsabilidad social empresarial) y ACTUAR (Evaluación - revisión de los resultados obtenidos - y Auditoría interna en responsabilidad social empresarial). 
De lo evidenciado sobre el tema en Colombia, se observa que han existido cuatro (4) proyectos de ley radicados sobre la responsabilidad social y ambiental, los cuales no han logrado convertirse en norma vigente, es decir se han archivado por diferentes causas dentro del Congreso de la República, entre ellas: debilidad argumentativa, falta de voluntad y gestión política y gubernamental.

Se recomienda al Gobierno Nacional estimule por conservar, preservar, proteger los recursos naturales renovables, creando incentivos económicos u alternativos, entre ellos: • Exoneración del impuesto predial a predios dedicados a la conservación y Puntajes adicionales en Licitaciones públicas. • Facilidades de acceso a créditos superiores para determinado monto. • Acceso a programas de fomento para micro y pequeñas empresas. • Fomento de Innovación Tecnológica y prioridad para la educación superior, entre otros; todos enfocados a fortalecer el actuar por parte de las empresas e industrias en la preservación, conservación o recuperación de nuestros recursos naturales renovables, sinónimos de vida y no de sobrevivencia.

Incentivo económico, expresado en dispositivos tales como subsidios, impuestos, donaciones, tasas retributivas, préstamos, y otros similares, mediante los cuales la administración pública descarga en el libre juego de las fuerzas económicas y del mercado, una parte de la responsabilidad estatal para prevenir y controlar la contaminación. (Borrero, 1994, p. 64)

Los instrumentos económicos son, de acuerdo a lo expuesto, una alternativa de gestión ambiental, que puede ser aplicable para el país (adopción de medidas costo-eficaces), pues apuntan a soluciones reales, a los problemas crecientes que han causado el deterioro ambiental, ya que la flexibilidad que ofrecen permite a los agentes minimizar el costo de cumplimiento con el marco legal ambiental, minimizando así el costo total en que la sociedad debe incurrir para lograr reducir la contaminación.

Y por último, en busca de lograr una planificación ambiental mundial, se recomienda que el Gobierno Nacional, gestione ante la Organización de las Naciones Unidas - ONU la creación de la Organización Internacional Ambiental - OIA, orientados a trazar políticas ambientales internacionales, seguimiento al respecto, y líneas de unificación de la legislación ambiental del mundo, enfocado a proteger "La vida de la Tierra".

Gracias:. 


\section{ESTRUCTURA}

\section{SISTEMA DE PLANIFICACION AMBIENTAL - SPAN}






\section{LISTA DE REFERENCIAS}

Textos nacionales e internacionales, jurisprudencia, normativa, documentos electrónicos y reportes de medios de comunicación sobre el tema de investigación.

Bibliografía

Colombia, Sentencia, T-444 (Corte Constitucional, 12 de Octubre de 1993).

Colombia, Sentencia, C-243 (Corte Constitucional, 17 de Febrero de 1994).

Colombia, Sentencia, C-058 (Corte Constitucional, 17 de Febrero de 1994).

Colombia, Sentencia, C-059 (Corte Constitucional, 17 de febrero de 1994).

Colombia, Sentencia, C-423 (Corte Constitucional, 29 de Septiembre de 1994).

Colombia, Sentencia, T-257 (Corte Constitucional, 11 de Junio de 1996).

Colombia, Sentencia, C-495 (Corte Constitucional, 26 de Septiembre de 1996).

Colombia, Sentencia, C-535 (Corte Constitucional, 16 de Octubre de 1996).

Colombia, Sentencia, C-221 (Corte Constitucional, 29 de Abril de 1997).

Colombia, Sentencia, C-894 (Corte Constitucional, 7 de Octubre de 2003).

Colombia, Sentencia, C-189 (Corte Constitucional, 15 de Marzo de 2006).

Colombia, Sentencia, C-813 (Corte Constitucional, 19 de Noviembre de 2009).

Colombia, Sentencia, C-598 (Corte Constitucional, 27 de Julio de 2010).

Colombia, Sentencia, C-263 (Corte Constitucional, 6 de Abril de 2011).

Colombia, Sentencia, C-010 (Corte Constitucional, 23 de Enero de 2013).

ADN. (29 de Julio de 2014). Acuerdo por la sequía pide FEDEMUNICIPIOS. ADN, pág. 4.

Amaya, O. D. (2002, pp. 204 y 205). La Constitución Ecológica de Colombia. Bogotá: Panamericana, formas e impresos.

Asamblea Nacional Constituyente. (1991). Informe de Ponencia Medio Ambiente y Recursos Naturales. Gaceta Constitucional, (pág. 46 a 51). Bogotá.

Azqueta, D. (1997). Valoración económica de la Calidad Ambiental. Universidad de Alcalá de Henares: MaGraw-Hill. 
Borrero, N. J. (1994, p. 64). Los Derechos Ambientales. Una Visón desde el Sur. Cali: Talleres Gráficos de Impresora Feriva. ISBN: 958-9234-03-8.

Brailovsky, E. A. (1997, Pp. 140 y 141). Una Constitución Ecologista. En C. d. Beliz, Guía Práctica Ecología Urbana (Vols. ISBN: 987-96446). Buenos Aires, Argentina: Gráfica Porteña S.A.

Brañes, R. (2000, p.26). Manual de Derecho Ambiental Mexicano. México: Fundación Mexicana para la educación ambiental y Fondo de Cultura Económica.

Cardena, G. A. (2001). Evolución del Derecho Penal frente a la Ecología en Colombia. En U. E. Colombia, Lecturas sobre Derechos del Medio Ambiente (pág. 399). Edicción primera: Bogotá: Panamericana Formas e Impresos S.A.

CECODES. (2014). Consejo Empresarial Colombiano para el Desarrollo Sostenible. Recuperado el 19 de Septiembre de 2014, de http://www.cecodes.org.co/index.php/acerca-de-cecodes/quienes-somos.html

Colombia, Congreso Nacional de la República. (1973). Ley 23 del 12 de diciembre de 1973. "Por la cual se conceden facultades extraordinarias al Presidente de la República para expedir el Código de Recursos Naturales y de Protección al Medio Ambiente". Diario oficial 34001, 12 de diciembre de 1973, Bogotá.

Colombia, Congreso Nacional de la República. (1993). Ley 99 del 22 de diciembre de 1993. "Por la cual se crea el Ministerio del Medio Ambiente, se reordena el Sector Público encargado de la gestión y conservación del medio ambiente y los recursos naturales renovables, se organiza el Sistema Nacional Ambiental, SINA". Diario Oficia № 41.146, 22 de diciembre de 1993, Bogotá.

Colombia, Congreso Nacional de la República. (1997). Ley 388 del 18 de julio de 1997. "Por la cual se modifica la Ley 9 de 1989, y la Ley 2 de 1991 y se dictan otras disposiciones". Diario oficial 43.091, 18 de julio de 1997, Bogotá.

Colombia, Congreso Nacional de la República. (2013). Ley 1617 del 5 de febrero de 213. "Por la cual se expide el Régimen para los Distritos Especiales". Diario Oficial № 48.695, 05 de febrero de 2013, Bogotá.

Colombia, Congreso Nacional de la República. (2013). Ley 1625 del 29 de abril de 2013. "Por la cual se derogo la Ley Orgánica 128 de 1994 y se expide el 
Régimen para las Áreas Metropolitanas". Diario Oficial № 48.776, 29 de abril de 2013, Bogotá.

Colombia, Departamento Administrativo de la Función Pública. (2011). Decreto 3570 del 27 de septiembre de 2011. "Por el cual se modifican los objetivos y la estructura del Ministerio de Ambiente y Desarrollo Sostenible y se integra el Sector Administrativo de Ambiente y Desarrollo Sostenible". Diario Oficial 48.205, 27 de septiembre de 2011.

Colombia, Departamento Administrativo de la Función Pública. (2011). Decreto 3572 del 27 de septiembre de 2011. "Por el cual se crea una Unidad Administrativa Especial, se determinan sus objetivos, estructura y funciones" Parques Nacionales Naturales de Colombia. Diario Oficial 48.205, 27 septiembre de 2011, Bogotá.

Colombia, Departamento Administrativo de la Función Pública. (2011). Decreto 3573 del 27 de septiembre de 2011. la Autoridad Nacional de Licencias Ambientales . Diario Oficial № 48.205, 27 de septiembre de 2011, Bogotá.

Colombia, Ministerio del Interior y de Justicia. (2010). Decreto 4580 de diciembre 07 de 2010. "Por el cual se declara el estado de emergencia económico, social y ecológico por razon de grave calamidad pública". Diario oficial № 47916 de diciembre 07 de 2010, Bogotá.

Comisión de las Comunidades Europeas. (18 de Julio de 2001, pp. 8 y 9). Europa UE. Recuperado el 28 de Agosto de 2014, de Fomentar un Marco Europeo para la Responsabilidad de las Empresas: http://eur-lex.europa.eu/legalcontent/ES/TXT/PDF/?uri=CELEX:52001DC0366\&from=ES

Constitución Política. (1991). Bogotá: Legis.

Contraloría General de la República. (31 de diciembre de 2013, Pp. 18 y 19). Contraloriagen. Recuperado el 15 de marzo de 2015, de CGR: http://www.contraloriagen.gov.co/documents/10136/76600464/INFORME_MEDI O_AMBIENTE_2012_2013_def_web.pdf/8c07cbcf-1186-4543-a08d$46 \mathrm{e} 5 \mathrm{e} 512 \mathrm{a} 27 \mathrm{c}$

CORNARE. (25 de Octubre de 2013). CORNARE. Recuperado el 23 de Agosto de 2014, de Subdirección General de Recursos Naturales: 
http://www.cornare.gov.co/banco-

proyectos/documentos/Anexo_Criterios_proyectos_Saneamiento_Tanques_septi cos_V.01.pdf

EEA. (2013). Agencia Europea de Medio Ambiente. Recuperado el 18 de 09 de 2014, de http://www.eea.europa.eu/es/about-us/who

EFE, Nueva York. (28 de Agosto de 2014). Alerta Informe de la ONU. El Calentamiento Global Crece y es Irreversible, pág. 9A.

Fundación especializada en sistemas y servicios. (2013, p. 10). Pedagogía Constitucional Colombiana. Bucaramanga: Fundación E.S.S. - E.P.S.

German Agency for Technical Cooperation, NU. CEPAL. (2008, p. 82). Análisis Económico de Externalidades Ambientales. (CEPAL, Ed.) Recuperado el 26 de 04 de 2015, de CEPAL: http://www.cepal.org/es/publicaciones/3624-analisiseconomico-de-externalidades-ambientales-guia-para-decisores

ICONTEC NC ISO 14001 - 14009. (s.f.). Sistema de gestión ambiental. Directrices sobre principios sistemas y técnicas de apoyo. Bogotá.

IDEAM. (2009). Instituto de Hidrología, Metereología y Estudios Ambientales. Recuperado el 24 de abril de 2015, de http://www.cambioclimatico.gov.co/jsp/anivel-nacional_1329

Intergovernmental Panel on Climate Change. (1988). IPCC. Recuperado el 16 de Septiembre de 2014, de http://www.ipcc.ch/home_languages_main_spanish.shtml

Konrad Adenauer Stifung. (2012, p. 9). Descentralización y Medio Ambiente en Colombia. En H. Gehring. Bogotá: Opciones Gráficas Editoriales Ltda.

Mantilla, P. E. (2013, p. 19). Medición de la Sostenibilidad Ambiental. Bucaramanga: Universidad Externado de Colombia.

Mochón, M. F. (2005). Principios de la Economía. Edicción tercera, España: Mc GrawHill Interamerciana.

Nación y Provincia de Buenos Aires. (2011, P. 279). Legislación Ambiental. Edicción octava, Buenos Aires, Argentina: Ediciones del País.

Naranjo, V. M. (1995, pp. 354 y 355). Teoría Constitucional e Instituciones Políticas. Bogotá, Colombia: Temis. 
Narváez, J. R. (2013). Manual de Investigación Jurisprudencial. Recuperado el 24 de abril de 2015, de Instituto de Investigaciones Jurisprudenciales y de Difusión y Promoción de la Ética Judicial - SCJN: www.sitios.scjn.gob.mx/instituto/sites/default/files/documentos/manualjurisprudencial.pdf

ODM. (1 de Enero de 2014). PNUD - Programa de las Naciones Unidas para el Desarrollo. Recuperado el 20 de Agosto de 2014, de ODM - Objetivos del Desarrollo del Milenio: http://www.undp.org/content/undp/es/home/librarypage/mdg/the-millenniumdevelopment-goals-report-2014/

ONU. (1987, p. 46). Informe de la Comisión Mundial sobre el Medio Ambiente y el Desarrollo. Madrid: Alianza Editorial.

ONU. (14 de junio de 1992). Organización de las Naciones Unidas. Recuperado el 30 de julio de 2014, de Declaración de río sobre el medio ambiente y el desarrollo: http://www.un.org/spanish/esa/sustdev/documents/declaracionrio.htm

ONU. (11 de Septiembre de 2012). Naciones Unidas. Recuperado el 24 de Agosto de 2014, de RIO + 20: http://www.un.org/es/sustainablefuture/about.shtml

ONU. (01 de 01 de 2012). Naciones Unidas. Recuperado el 2014 de Agosto de 2014, de RIO + 20: http://www.un.org/es/sustainablefuture/about.shtml

ONU. (20 al 22 de Junio de 2012). Organización de las Naciones Unidas. Recuperado el 25 de Agosto de 2014, de Conferencia de las Naciones Unidas para el Desarrollo Sostenible $\mathrm{RIO}$ 20: file://D:/LMC.\%20junio\%2004\%20DE\%202014/LEGISLACION/NORMATIVIDAD \%20AMBIENTAL/2012/RIO\%20+\%2020.pdf

Ostau, d. I. (2012, p. 92). La Responsabilidad Social Empresarial en las Empresas del Sector Carfonífero Colombiano. En Lecciones y Experiencias de las Empresas Mineras en el Marco de los Estándares Internacionales. Dialógos de Saberes: Investigación y Ciecias Sociales. ISSN 0124-0021, № 36.

PNUD. (2014). Programa de las Naciones Unidas para el Desarrollo. Recuperado el 16 de Septiembre de 2014 , de IPCC: 
http://www.undp.org/content/undp/es/home/ourwork/environmentandenergy/abou t_enregy_andenvironment/

PNUMA. (2014). Programa de las Naciones Unidas para el Medio Ambiente. Recuperado el 17 de Septiembre de 2014, de http://www.pnuma.org/gobernanza/index.php

Ponce de León, C. E. (2005, Pp. 52 y 53). Estudio Jurídico sobre Categorías Regionales de Áreas Protegidas. (I. d. Humboldt, Ed.) Bogotá: Ramos Lopéz Editorial. ISBN:8151-39-2.

Quijano, Henry. Konrad Adenauer Stiftung. (2012, p. 61). Descentralización y Medio Ambiente en Colombia. En La Multiescalaridad Territorial y el Cambio Climático. Bogotá: Opciones Gráficas Editores Ltda.

Rodriguez, M. D. (1995). Centro Panamericano de Ecología Humana y Salud - ECO. Recuperado el 15 de abril de 2015, de Glosario de términos en salud ambiental: www.osman.es/ficha/13610

Rojas, Q. S. (2012, Pp. 40 y 41). La Responsabilidad Civil por Afectaciones Ambientales. Bogotá: Grupo Editorial Ibáñez. ISBN: 978-958-749-193-7.

Vanguardia Liberal. (29 de julio de 2014). (P. V. Liberal, Ed.) Recuperado el 27 de abril de 2015, de http://www.vanguardia.com/santander/bucaramanga/271320-tironde-orejas-a-452-alcaldes-por-no-tomar-medidas-ante-el-nino

Vanguardia Liberal. (29 de Julio de 2014). Llamado de atención lo hizo el procurador delegado a los alcaldes. Tirón de orejas a 452 alcaldes por no tomar medidas, pág. 2A.

Vanguardia Liberal. (15 de Septiembre de 2014). Se debatirá sobre justicia ambiental. Colombia es el país con más conflictos ambientales, pág. 5A. 